Supporting Information

\title{
Mediator-Enabled Electrocatalysis with Ligandless Copper for Anaerobic Chan-Lam Coupling Reactions
}

\author{
Benjamin R. Walker, ${ }^{\sharp}$ Shuhei Manabe,${ }^{\S \sharp}$ Andrew T. Brusoe, ${ }^{\ddagger}$ Christo S. Sevov,${ }^{\S *}$ \\ ${ }^{\S}$ Department of Chemistry and Biochemistry, The Ohio State University, $151 \mathrm{~W}$ Woodruff Avenue, Columbus, $\mathrm{OH}$ \\ 43210, United States \\ Chemical Development, Boehringer Ingelheim Pharmaceuticals, Inc., 900 Ridgebury Road, P.O. Box 368, \\ Ridgefield, Connecticut 06877-0368, United States
}

sevov.1@osu.edu 
General Remarks..................................................................................................S3

General Procedure for Electrochemical Chan-Lam-Evans Coupling........................................S4

General Procedure for Scale-Up Electrochemical Chan-Lam-Evans Coupling..............................S4

List of Tested Redox Mediators........................................................................S4

CVs of $\mathrm{Cu}(0)$ Stripping from Electrode...................................................................S5

EDX-SEM Data......................................................................................S5

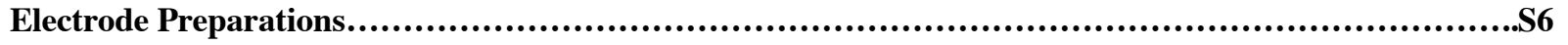

Isolated Product Characterization.........................................................................S8

Substrate Scope Limitations............................................................................S16

Additional Studies on Reaction Development..............................................................S16

References.............................................................................................S18

Reproduced Copies of Spectra...............................................................................S20 


\section{General Remarks}

Unless otherwise noted, all experiments were conducted under a dry atmosphere of nitrogen to confirm that electrochemistry, rather than oxygen, is the source of oxidative turnover. Reaction cells were assembled in a nitrogenfilled dry box, and all chemicals were used without further purification. Anhydrous acetonitrile was purchased from Millipore Sigma. Tetrabutylammonium hexafluorophosphate was purchased from Chem-Impex and recrystallized from ethanol prior to use. Ferrocenium hexafluorophosphate was synthesized according to literature procedure. ${ }^{1}$

${ }^{1} \mathrm{H}$ NMR spectra were obtained at 400 or $600 \mathrm{MHz}$ and chemical shifts were recorded relative to $\mathrm{CHCl}_{3}$ in $\mathrm{CDCl}_{3}$ $(\delta 7.26 \mathrm{ppm}) .{ }^{13} \mathrm{C}$ NMR were obtained at $101 \mathrm{MHz} .{ }^{19} \mathrm{~F}$ NMR were obtained at $377 \mathrm{MHz}$. Proof of purity is demonstrated by copies of NMR spectra and high resolution mass spectrometry. NMR multiplicities are reported as follows: singlet (s), doublet (d), triplet (t), quartet (q), multiplet (m), broad signal (br). GC analysis was performed on an Agilent 7890B GC equipped with an HP-5 column (30 m x $0.32 \mathrm{~mm} \times 0.25 \mu \mathrm{m}$ film) and an FID detector. Quantitative GC analysis was performed by adding dodecane as an internal standard to the reaction mixture upon completion of the reaction. Response factors for the products relative to the internal standard were measured for reaction development.

All electrochemical analyses were carried out in a nitrogen-filled glovebox. The supporting electrolyte was potassium hexafluorophosphate. Cyclic voltammetry was performed with a Biologic VSP multichannel potentiostat/galvanostat. Cyclic voltammetry was carried out in a three electrode electrochemical cell, consisting of a glassy carbon disk working electrode $\left(0.07 \mathrm{~cm}^{2}, \mathrm{BASi}\right), \mathrm{a} \mathrm{Ag} / \mathrm{Ag}^{+}$quasi-reference electrode (BASi) with $0.01 \mathrm{M}$ $\mathrm{AgBF}_{4}$ (Sigma) in $\mathrm{MeCN}$, and a platinum wire counter electrode $(23 \mathrm{~cm}, \mathrm{ALS})$. The glassy carbon disk electrode was polished in a nitrogen-filled glovebox using diamond polish (15 $\mu \mathrm{m}, \mathrm{BASi})$ and anhydrous MeCN. All experiments were performed at a scan rate of $100 \mathrm{mV} / \mathrm{s}$ in a $\mathrm{MeCN}$ electrolyte containing $0.1 \mathrm{M} \mathrm{KPF}_{6}$ unless otherwise noted. Reference electrodes were calibrated against an internal voltage reference of ferrocene (1-10 $\mathrm{mM})$. Reactions were conducted as two-electrode cells with a LANHE LAND battery testing system using nickel foam $(1.5 \mathrm{~mm} \times 250 \mathrm{~mm}$ x $200 \mathrm{~mm}, 110$ ppi, 99.8\% purity, purchased from Amazon.com) and platinum (6 mm x 1.5mm x $30 \mathrm{~mm}$, purchased from Shanghai Jie Yu Electronic Technology Co., Ltd.) electrodes. Reactions were conducted in Fisherband disposable borosilicate glass tubes with a threaded end $(16 \times 100 \mathrm{~mm})$. 


\section{General Procedure for Electrochemical Chan-Lam-Evans Coupling}

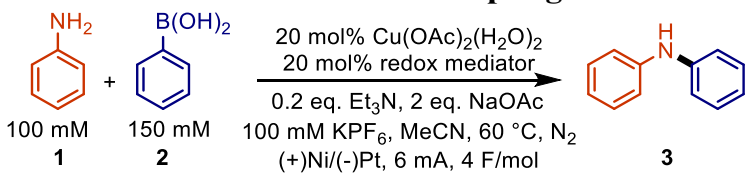

In a nitrogen filled glove box, a $10 \mathrm{~mL}$ reaction vial was charged with a stir bar, aniline ( $28 \mathrm{mg}, 0.30 \mathrm{mmol})$, $\mathrm{MeCN}(3 \mathrm{~mL})$, triethylamine $(6 \mathrm{mg}, 0.06 \mathrm{mmol}), \mathrm{KPF}_{6}(55 \mathrm{mg}, 0.30 \mathrm{mmol})$, phenylboronic acid $(55 \mathrm{mg}, 0.45 \mathrm{mmol})$, $\mathrm{Cu}(\mathrm{OAc})_{2} \bullet 2 \mathrm{H}_{2} \mathrm{O}(13 \mathrm{mg}, 0.060 \mathrm{mmol}), \mathrm{NaOAc}(49 \mathrm{mg}, 0.60 \mathrm{mmol})$, and ferrocenium hexafluorophosphate (20. $\mathrm{mg}$, $0.060 \mathrm{mmol})$, in this order. The reaction vial was sealed with a septa-lined cap. A Ni foam electrode $(6 \mathrm{~mm} \times 30 \mathrm{~mm})$ and a Pt electrode $(6 \mathrm{~mm} \times 30 \mathrm{~mm})$ pierced through the septa and were submerged to a depth of $5 \mathrm{~mm}$ into the solution. An oxidative current was then applied to the $\mathrm{Ni}$ foam electrode $(3 \mathrm{~mA}, 32.2 \mathrm{mAh}, 4$ equiv e- $)$ at $40{ }^{\circ} \mathrm{C}$ and vigorously stirred (700 rpm). Following the electrolysis, the reaction mixture was concentrated and loaded onto silica and purified by flash column chromatography. The conditions for chromatography and other data that are specific to each compound are given below.

\section{General Procedure for Scale-Up Electrochemical Chan-Lam-Evans Coupling}

Under air, a $1 \mathrm{~L}$ media bottle was charged in the following order with a stir bar, aniline $(2.79 \mathrm{~g}, 30.0 \mathrm{mmol})$, $\mathrm{MeCN}(300 \mathrm{~mL})$, triethylamine $(607 \mathrm{mg}, 6.00 \mathrm{mmol}), \mathrm{KPF}_{6}(5.52 \mathrm{~g}, 30.0 \mathrm{mmol})$, phenylboronic acid $(5.49 \mathrm{~g}, 45.0$ $\mathrm{mmol}), \mathrm{Cu}(\mathrm{OAc})_{2} \bullet 2 \mathrm{H}_{2} \mathrm{O}(1.20 \mathrm{~g}, 6.00 \mathrm{mmol}), \mathrm{NaOAc}(4.92 \mathrm{~g}, 60.0 \mathrm{mmol})$, and ferrocenium hexafluorophosphate $(2.08 \mathrm{~g}, 6.00 \mathrm{mmol})$. The media bottle was then sealed with a three-port cap that had a RVC anode $(25 \mathrm{~mm} \mathrm{x} 10 \mathrm{~mm}$ x $50 \mathrm{~mm}$ ) and a Pt electrode $(25 \mathrm{~mm} \times 30 \mathrm{~mm}$ ) pierced through to allow for connection of the electrical leads. The head space of the media bottle was exchanged with nitrogen and an oxidative current was then applied to the RVC electrode (100 mA, $3800 \mathrm{mAh}, 4.7$ equiv e-) at $60{ }^{\circ} \mathrm{C}$ while stirring $(150 \mathrm{rpm})$. The Pt electrodes were periodically agitated to remove any deposited salts. Following the electrolysis, the crude reaction mixture was concentrated, loaded onto silica, and purified by flash column chromatography with $2 \%$ EtOAc in hexanes to afford the purified product as a white solid $(3.66 \mathrm{~g}, 72 \%)$.

\section{Classes of Tested Mediators}

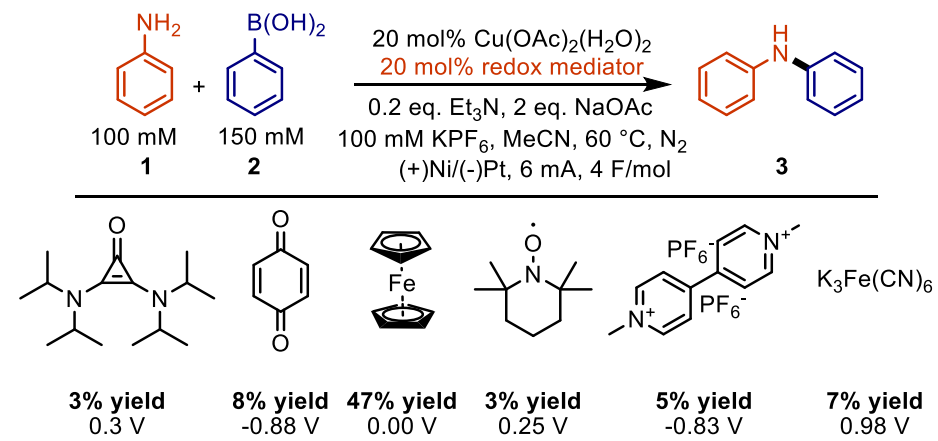

Figure S1. List of tested redox mediator classes with yields reported using GC analysis with dodecane as an internal standard and redox potentials listed vs $\mathrm{Fc} / \mathrm{Fc}^{+}$. 


\section{CVs of $\mathrm{Cu}(0)$ Stripping from Electrode}

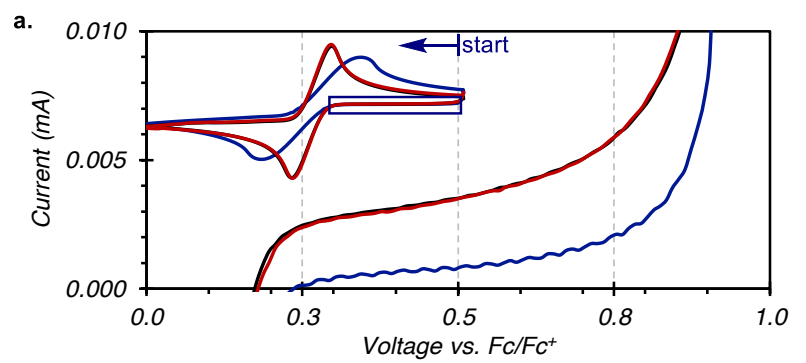

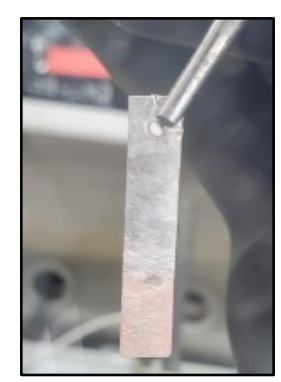

$\mathrm{T}_{0} œ \mathrm{Cu}^{0}$ plated electrode

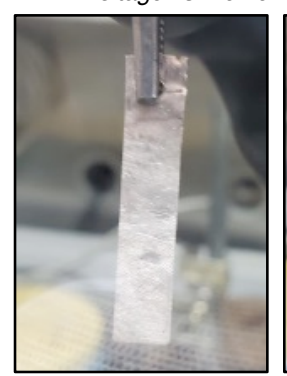

10 seconds in $20 \mathrm{mM} \mathrm{Fc}$

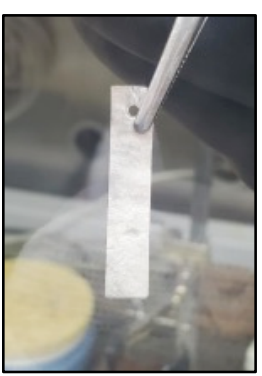

20 seconds in $20 \mathrm{mM} \mathrm{Fc}^{+}$

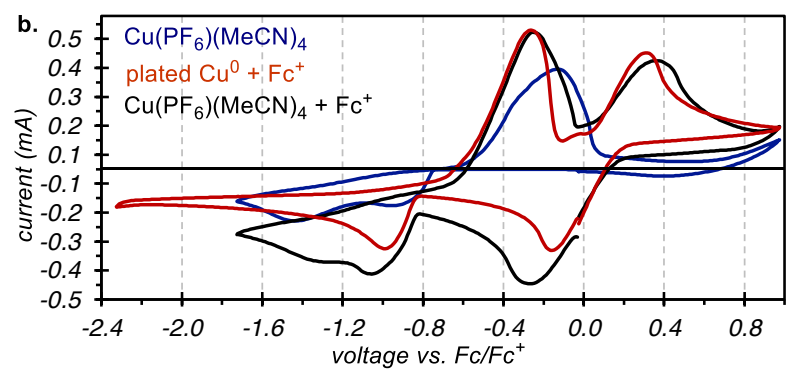

Figure S2. (a) Evaluation of $\mathrm{Cu}^{0}$ oxidation from the surface of a Pt electrode as a function of time. $\mathrm{CV}$ analysis of the initial solution of $20 \mathrm{mM} \mathrm{Fc}^{+}$(blue), the solution after exposure to the $\mathrm{Cu}^{0}$ plated electrode for 10 seconds (red), and the solution after exposure to $\mathrm{Cu}^{0}$ plated electrode for an additional 20 seconds (black). The corresponding photographs of the Pt electrode are provided below. (b) CVs supporting the formation of a $\mathrm{Cu}(\mathrm{II})$ salt following oxidative stripping of $\mathrm{Cu}$ metal with $\mathrm{Fc}^{+}$. $\mathrm{CV}$ of: $\mathrm{Cu}\left(\mathrm{PF}_{6}\right)(\mathrm{MeCN})_{4}$ solution (blue), $\mathrm{Fc}^{+}$solution after reacting with $\mathrm{Cu}^{0}$ coated electrode (red), $\mathrm{Cu}\left(\mathrm{PF}_{6}\right)(\mathrm{MeCN})_{4}$ with $\mathrm{Fc}^{+}$(black). The red and black $\mathrm{CV}$ s indicate that $\mathrm{Fc}$ has been formed by the positive current above $0 \mathrm{~V}$ and that the same copper salts have been formed by the similar current profiles.

\section{EDX-SEM Data}
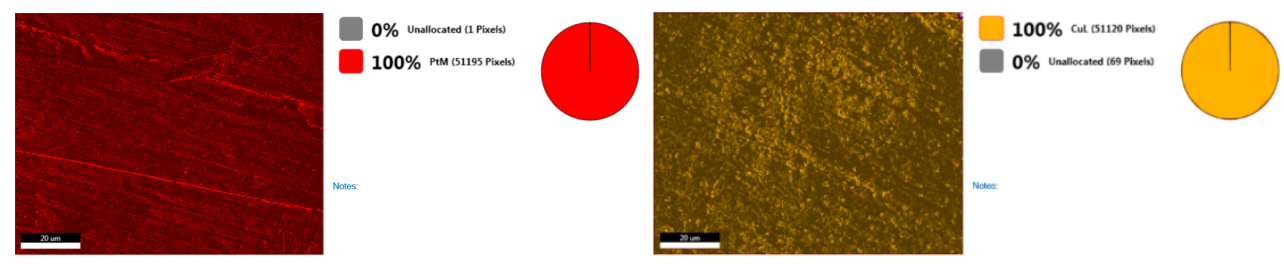

Figure S3. EDX-SEM images of platinum electrode after a reaction with $\mathrm{Fc}^{+}$(left, red) and of a platinum reaction after a reaction without $\mathrm{Fc}^{+}$(right, yellow). 


\section{Electrode Preparation}
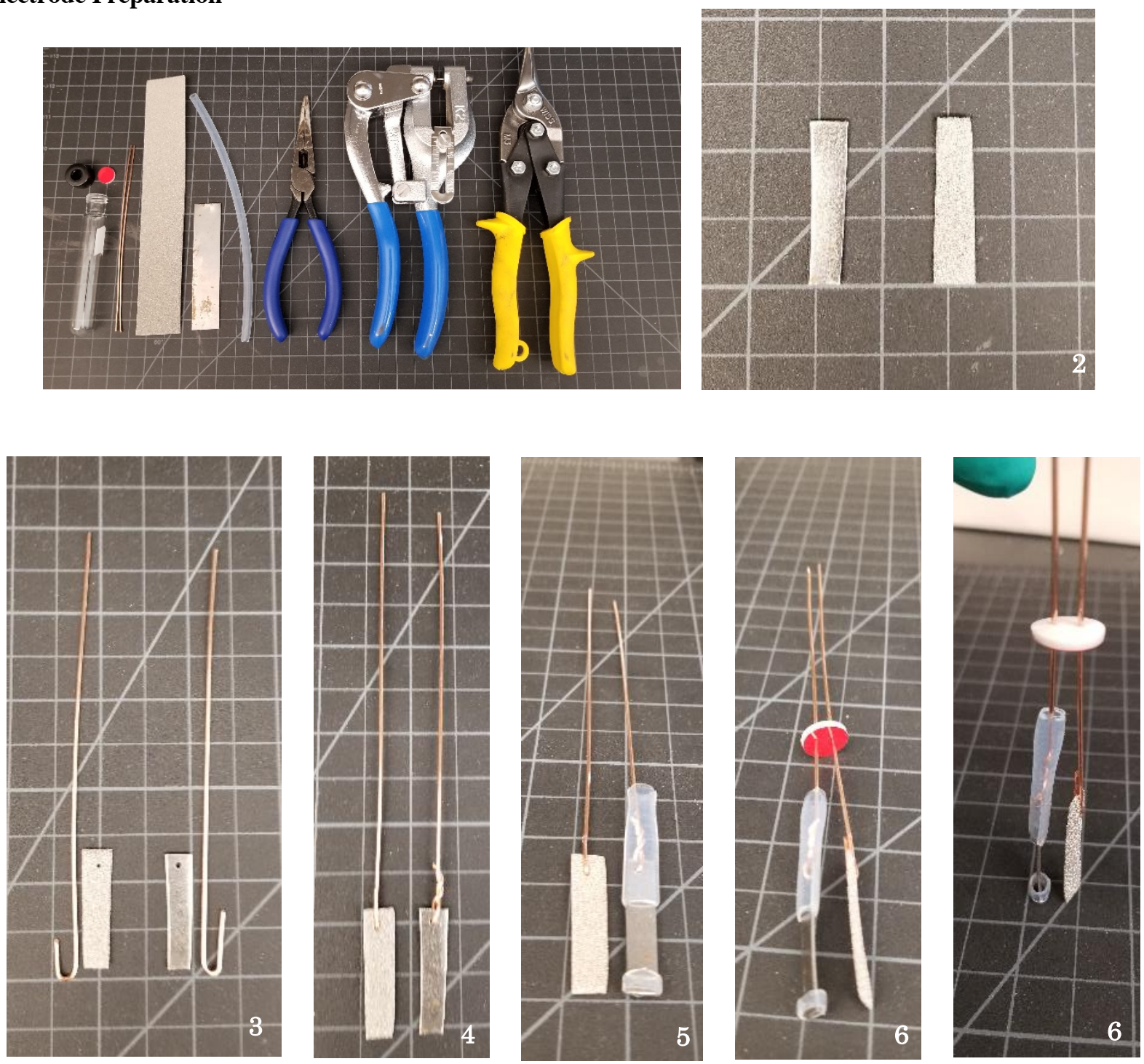


\section{Procedure for Electrode Preparation:}

1. Materials required: $12 \mathrm{~mL}$ threaded reaction test tube, PTFE septa, threaded test tube cap, copper wire (18 ga), nickel foam, platinum sheet, PTFE tubing (3/16" ID, 1/4" OD, 1/32"WT), pliers, hole punch, and tin snips.

2. Use tin snips to cut the nickel foam and platinum sheet into $6 \mathrm{~mm} \times 32 \mathrm{~mm}$ strips.

3. Use the hole punch to make a $1.2 \mathrm{~mm}$ hole in the nickel foam and platinum strip.

4. Secure the nickel foam and platinum strip to the copper wire. For the nickel foam cathode, the copper wire was threaded through the hole and the copper was folded back on itself to clamp the nickel foam in place. For the platinum anode, the copper wire was threaded through hole and then twisted over itself to ensure a secure connection.

5. On the platinum anode, a segment of PTFE tubing was cut and was placed over the platinum -copper connection - to prevent the electrodes from touching.

6. Copper wire from the nickel foam and platinum electrodes were pushed through PTFE septa and electrodes were positioned parallel to each other to prevent contact.

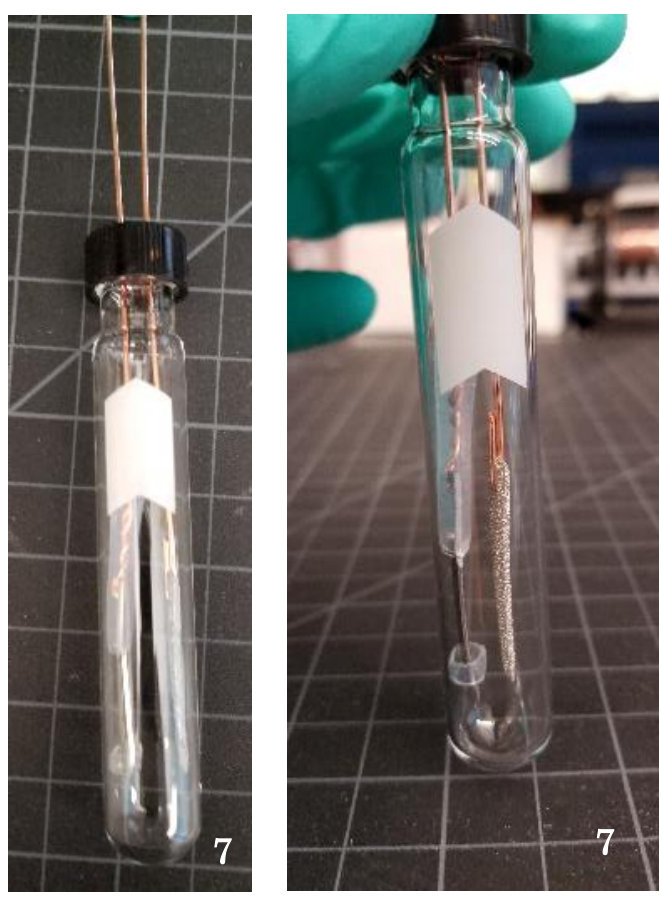

7. Pair of electrodes were slid into the test tube, inserted until a $1 \mathrm{~cm}$ gap remains at the bottom of the test tube. The septa was then secured with the threaded cap. 


\section{Characterization of Isolated Products}

\section{3 - Diphenylamine}

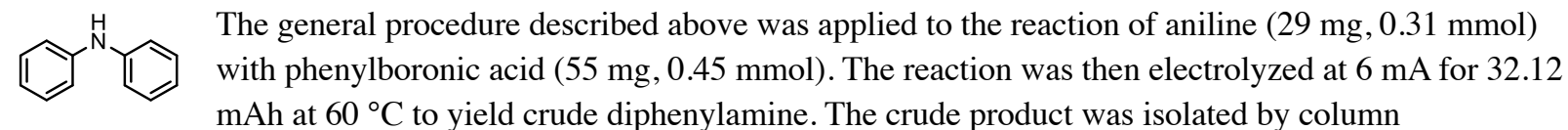

chromatography with $2 \%$ EtOAc in hexanes to afford the title compound as a white solid (42 $\mathrm{mg}, 81 \%)$.

Characterization data match those of previously reported literature. ${ }^{2}$

${ }^{1}$ H NMR: (400 MHz, Chloroform- $d$ ) $\delta: 7.30$ (tt, $\left.J=7.5,2.2 \mathrm{~Hz}, 4 \mathrm{H}\right), 7.14-7.09$ (m, 4H), 6.97 (tt, $J=7.5,1.1 \mathrm{~Hz}$, 2H), $5.71(\mathrm{~s}, 1 \mathrm{H})$.

${ }^{13}$ C NMR: $\left(101 \mathrm{MHz}, \mathrm{CDCl}_{3}\right) \delta: 143.2,129.5,121.1,117.9$.

HRMS-ESI (m/z): for $\mathrm{C}_{12} \mathrm{H}_{11} \mathrm{~N}$ [M+H']: calcd: 170.0969 , found: 170.0964

\section{4 - 4-Methyl- $N$-phenylaniline}

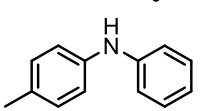

The general procedure described above was applied to the reaction of 4-toluidine ( $32 \mathrm{mg}, 0.30 \mathrm{mmol}$ ) with phenylboronic acid $(55 \mathrm{mg}, 0.45 \mathrm{mmol})$. The reaction was then electrolyzed at $3 \mathrm{~mA}$ for 32.16 $\mathrm{mAh}$ at $40{ }^{\circ} \mathrm{C}$ to yield crude 4 -methyl- $N$-phenylanilne. The crude product was isolated by column chromatography with $2 \%$ EtOAc in hexanes to afford the product as an orange liquid (42 $\mathrm{mg}, 76 \%$ ). Characterization data match those of previously reported literature. ${ }^{2}$

'H NMR: (400 MHz, $\left.\mathrm{CDCl}_{3}\right)$ d: $7.22-7.09(\mathrm{~m}, 2 \mathrm{H}), 7.00(\mathrm{~d}, J=8.2 \mathrm{~Hz}, 2 \mathrm{H}), 6.94-6.87(\mathrm{~m}, 4 \mathrm{H}), 6.79$ (tt, $J=7.3$, $1.1 \mathrm{~Hz}, 1 \mathrm{H}), 5.48(\mathrm{~s}, \mathrm{br}, 1 \mathrm{H}), 2.22(\mathrm{~s}, 3 \mathrm{H})$.

${ }^{13}$ C NMR: $\left(101 \mathrm{MHz}, \mathrm{CDCl}_{3}\right) \delta: 144.1,140.4,131.0,130.0,129.4,120.4,119.0,117.0,20.8$.

HRMS-ESI (m/z): for $\mathrm{C}_{13} \mathrm{H}_{13} \mathrm{~N}\left[\mathrm{M}+\mathrm{H}^{+}\right]$: calcd: 184.1126 , found 184.1122

\section{5 - 2,4,6-Trimethyl- $N$-phenylaniline}<smiles>Cc1cc(C)c(Nc2ccccc2C)c(C)c1</smiles>

The general procedure described above was applied to the reaction of 2,4,6-trimethylaniline (40 $\mathrm{mg}$, $0.30 \mathrm{mmol})$ with phenylboronic acid $(55 \mathrm{mg}, 0.45 \mathrm{mmol})$. The reaction was then electrolyzed at 6 $\mathrm{mA}$ for $72.36 \mathrm{mAh}$ at $60^{\circ} \mathrm{C}$ to yield crude $N$-methyl- $N$-phenylaniline. The crude product was isolated by column chromatography with $1 \%$ triethylamine and $2 \%$ EtOAc in hexanes to afford the product as an orange liquid (41 mg, 64\%). Characterization data match those of previously reported literature. ${ }^{3}$

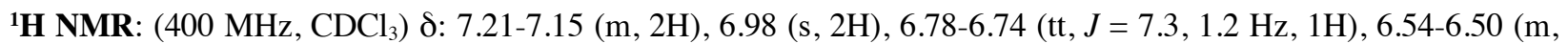
$2 \mathrm{H}), 5.12(\mathrm{~s} \mathrm{br}, 1 \mathrm{H}), 2.35(\mathrm{~s}, 3 \mathrm{H}), 2.21(\mathrm{~s}, 6 \mathrm{H})$.

${ }^{13}$ C NMR: (101 MHz, $\left.\mathrm{CDCl}_{3}\right) \delta: 146.8,136.1,135.5,129.3,129.3,118.0,113.4,21.0,18.4$.

HRMS-ESI (m/z): for $\mathrm{C}_{15} \mathrm{H}_{17} \mathrm{~N}$ [M+H']: calcd: 212.1439 , found: 212.1434

\section{6 - 2-Methyl- $N$-phenylaniline}<smiles>Cc1ccccc1Nc1ccccc1</smiles>

The general procedure described above was applied to the reaction of o-toluidine ( $32 \mathrm{mg}, 0.30 \mathrm{mmol}$ ) with phenylboronic acid $(55 \mathrm{mg}, 0.45 \mathrm{mmol})$. The reaction was then electrolyzed at $6 \mathrm{~mA}$ for 32.16 $\mathrm{mAh}$ at $60{ }^{\circ} \mathrm{C}$ to yield crude 2-methyl- $N$-phenylaniline. The crude product was isolated by column chromatography with 0 to $2 \%$ EtOAc in hexanes to afford the product as an orange liquid (27 $\mathrm{mg}, 50 \%)$. Characterization data match those of previously reported literature. ${ }^{2}$

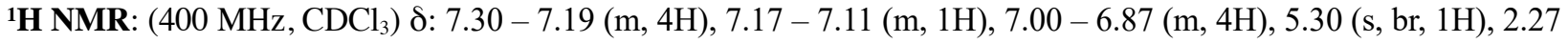
$(\mathrm{s}, 3 \mathrm{H})$

${ }^{13}$ C NMR: $\left(101 \mathrm{MHz}, \mathrm{CDCl}_{3}\right) \delta: 144.1,141.4,131.1,129.4,128.4,126.9,121.1,120.6,118.9,117.6,18.0$.

HRMS-ESI (m/z): for $\mathrm{C}_{13} \mathrm{H}_{13} \mathrm{~N}\left[\mathrm{M}+\mathrm{H}^{+}\right]$: calcd: 184.1126 , found 184.1122

\section{7 - 2-(Phenylamino)benzonitrile}

The general procedure described above was applied to the reaction of 2-aminobenzonitrile ( $35 \mathrm{mg}, 0.30$
$\mathrm{mmol})$ with phenylboronic acid $(55 \mathrm{mg}, 0.45 \mathrm{mmol})$. The reaction was then electrolyzed at $6 \mathrm{~mA}$ for
$32.16 \mathrm{mAh}$ at $60^{\circ} \mathrm{C}$ to yield crude 2-(phenylamino)benzonitrile. The crude product was isolated by 
column chromatography with $2 \%$ EtOAc in hexanes to afford the product as a slightly yellow solid (40 mg, $68 \%)$. Characterization data match those of previously reported literature. ${ }^{4}$

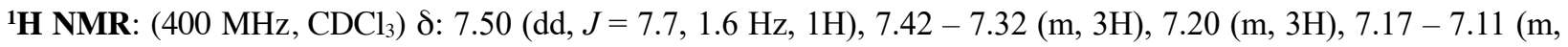
$1 \mathrm{H}), 6.84(\mathrm{td}, J=7.6,1.0 \mathrm{~Hz}, 1 \mathrm{H}), 6.33(\mathrm{~s}, \mathrm{br}, 1 \mathrm{H})$.

${ }^{13}$ C NMR: $\left(101 \mathrm{MHz}, \mathrm{CDCl}_{3}\right) \delta$ : 147.4, 140.1, 134.0, 133.2, 129.8, 124.4, 121.9, 119.3, 117.7, 114.3, 98.6.

HRMS-ESI (m/z): for $\mathrm{C}_{13} \mathrm{H}_{10} \mathrm{~N}_{2}\left[\mathrm{M}+\mathrm{H}^{+}\right]$: calcd: 195.0922 , found 195.0915

\section{8 - Methyl 4-(phenylamino)benzoate}

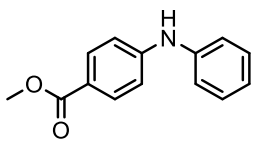

The reaction was performed according to the general procedure but at double the concentration. Methyl 4-aminobenzoate (90 mg, $0.60 \mathrm{mmol}$ ), phenylboronic acid (109 mg, $0.894 \mathrm{mmol}$ ) with triethylamine $(12 \mathrm{mg}, 0.12 \mathrm{mmol}), \mathrm{Cu}(\mathrm{OAc})_{2} \bullet 2 \mathrm{H}_{2} \mathrm{O}(26 \mathrm{mg}, 0.12 \mathrm{mmol})$, potassium hexafluorophosphate $(55 \mathrm{mg}, 0.30 \mathrm{mmol})$, sodium acetate $(49 \mathrm{mg}, 0.60 \mathrm{mmol})$, and ferrocenium hexafluorophosphate $(40 \mathrm{mg}, 0.12 \mathrm{mmol})$ were mixed in $\mathrm{MeCN}(3 \mathrm{~mL})$. The reaction was then electrolyzed at $3 \mathrm{~mA}$ for $64.32 \mathrm{mAh}$ at $40{ }^{\circ} \mathrm{C}$ to yield crude methyl-4-(phenylamino)benzoate. The crude product was isolated by column chromatography with $2 \sim 10 \%$ EtOAc, in hexanes to afford the product as a white solid (115 $\mathrm{mg}, 85 \%)$. Characterization data match those of previously reported literature. ${ }^{5}$

${ }^{1}$ H NMR: $\left(400 \mathrm{MHz}, \mathrm{CDCl}_{3}\right)$ 8: $8.01-7.86(\mathrm{~m}, 2 \mathrm{H}), 7.39-7.29(\mathrm{~m}, 2 \mathrm{H}), 7.22-7.14(\mathrm{~m}, 2 \mathrm{H}), 7.10-7.04(\mathrm{~m}, 1 \mathrm{H})$, $7.01-6.95(\mathrm{~m}, 2 \mathrm{H}), 6.04(\mathrm{~s}, 1 \mathrm{H}), 3.87(\mathrm{~s}, 3 \mathrm{H})$.

${ }^{13}$ C NMR: (101 MHz, $\left.\mathrm{CDCl}_{3}\right) \delta: 167.1,148.2,141.0,131.6,129.6,123.3,121.3,120.6,114.7,51.9$

HRMS-ESI $(\mathrm{m} / \mathrm{z})$ : for $\mathrm{C}_{14} \mathrm{H}_{13} \mathrm{NO}_{2}\left[\mathrm{M}+\mathrm{H}^{+}\right]$: calcd: 228.1025 , found 228.1016

\section{9 - $N$-Phenyl-3,5-bis(trifluoromethyl)aniline}<smiles>FC(F)(F)c1cc(Nc2ccccc2)cc(C(F)(F)F)c1</smiles>

The general procedure described above was applied to the reaction of 3,5bis(trifluoromethyl)aniline (70 mg, $0.30 \mathrm{mmol}$ ) with phenylboronic acid $(55 \mathrm{mg}, 0.45 \mathrm{mmol}$ ).

The reaction was then electrolyzed at $3 \mathrm{~mA}$ for $32.16 \mathrm{mAh}$ at $40{ }^{\circ} \mathrm{C}$ to yield crude $N$-phenyl-3,5bis(trifluoromethyl)aniline. The crude product was isolated by column chromatography with $2 \%$

EtOAc in hexanes to afford the product as a slightly orange solid $(55 \mathrm{mg}, 60 \%)$. Characterization data match those of previously reported literature. ${ }^{6}$

${ }^{1}$ H NMR: (400 MHz, Chloroform- $d$ ) $\delta 7.40-7.35$ (m, 4H), 7.32 (s, 1H), $7.16-7.10$ (m, 3H), 5.98 (s, br, 1H). ${ }^{19}$ F NMR: $\left(376 \mathrm{MHz}, \mathrm{CDCl}_{3}\right) \delta-63.22$.

${ }^{13}$ C NMR: $\left(101 \mathrm{MHz}, \mathrm{CDCl}_{3}\right) \delta 145.5,140.5,132.9$ (q, $\left.J=33.0 \mathrm{~Hz}\right), 130.0,124.9,122.9(\mathrm{q}, J=272.7 \mathrm{~Hz}), 120.6$, $115.3(\mathrm{q}, J=4.0 \mathrm{~Hz}), 113.1$ (hept, $J=4.0 \mathrm{~Hz}$ ).

HRMS-ESI (m/z): for $\mathrm{C}_{14} \mathrm{H}_{9} \mathrm{~F}_{6} \mathrm{~N}$ [M+H'] : calcd: 306.0717 , found: 306.0707

\section{0 - N-Phenyl-4-(trifluoromethoxy)aniline}<smiles>[C+]#COc1ccc(Nc2ccccc2)cc1</smiles>
The general procedure described above was applied to the reaction of 4(trifluoromethoxy)aniline (58 mg, $0.33 \mathrm{mmol}$ ) with phenylboronic acid (55 mg, $0.45 \mathrm{mmol})$. The reaction was then electrolyzed at $6 \mathrm{~mA}$ for $32.12 \mathrm{mAh}$ at $60^{\circ} \mathrm{C}$ to yield crude $\mathrm{N}$-phenyl-4(trifluoromethoxy)aniline. The crude product was isolated by column chromatography with $2 \%$ EtOAc in hexanes to afford the title compound as a white solid (35 $\mathrm{mg}, 42 \%)$. Characterization data match those of previously reported literature. $^{7}$

${ }^{1}$ H NMR: (400 MHz, Chloroform- $d$ ) $\delta 7.37-7.27(\mathrm{~m}, 2 \mathrm{H}), 7.16-7.02(\mathrm{~m}, 6 \mathrm{H}), 6.99(\mathrm{t}, J=7.3 \mathrm{~Hz}, 1 \mathrm{H}), 5.71(\mathrm{~s}$, $1 \mathrm{H})$.

${ }^{19}$ F NMR: $\left(376 \mathrm{MHz}, \mathrm{CDCl}_{3}\right) \delta-58.29$.

${ }^{13} \mathrm{C}$ NMR: ${ }^{13} \mathrm{C}$ NMR $\left(101 \mathrm{MHz}, \mathrm{CDCl}_{3}\right) \delta 142.9,142.7,142.3,129.6,122.5,121.9,120.28$ (q, $\left.J=256.3 \mathrm{~Hz}\right), 118.5$, 118.3 .

HRMS-ESI (m/z): for $\mathrm{C}_{13} \mathrm{H}_{10} \mathrm{~F}_{3} \mathrm{NO}$ [M+H+ $\mathrm{H}^{+}$: calcd: 254.0792 , found: 254.0788

\section{1 - 4-Chloro- $N$-phenylaniline}


<smiles>Clc1ccc(Nc2ccccc2)cc1</smiles>

The general procedure described above was applied to the reaction of 4-chloroaniline ( $43 \mathrm{mg}, 0.34$ $\mathrm{mmol}$ ) with phenylboronic acid $(55 \mathrm{mg}, 0.45 \mathrm{mmol})$. The reaction was then electrolyzed at $3 \mathrm{~mA}$ for $32.12 \mathrm{mAh}$ at $40{ }^{\circ} \mathrm{C}$ to yield crude 4-chloro- $N$-phenylaniline. The crude product was isolated Characterization data match those of previously reported literature. ${ }^{5}$

${ }^{1}$ H NMR: (400 MHz, Chloroform- $d$ ) $\delta 7.35-7.27(\mathrm{~m}, 2 \mathrm{H}), 7.25-7.19(\mathrm{~m}, 2 \mathrm{H}), 7.06(\mathrm{~d}, J=7.7 \mathrm{~Hz}, 2 \mathrm{H}), 7.03-$ $6.92(\mathrm{~m}, 3 \mathrm{H}), 5.67(\mathrm{~s}, 1 \mathrm{H})$.

${ }^{13}$ C NMR: $\left(101 \mathrm{MHz}, \mathrm{CDCl}_{3}\right) \delta 142.8,142.0,129.6,129.4,125.6,121.6,118.9,118.2$.

HRMS-ESI (m/z): for $\mathrm{C}_{12} \mathrm{H}_{10} \mathrm{ClN}$ [M+H']: calcd: 204.0580, found: 204.0573

\section{2 - 4-Bromo- $N$-phenylaniline}<smiles>Brc1ccc(Nc2ccccc2)cc1</smiles>

The general procedure described above was applied to the reaction of 4-bromoaniline ( $60 \mathrm{mg}$, $0.35 \mathrm{mmol})$ with phenylboronic acid $(55 \mathrm{mg}, 0.45 \mathrm{mmol})$. The reaction was then electrolyzed at 3 $\mathrm{mA}$ for $32.12 \mathrm{mAh}$ at $40{ }^{\circ} \mathrm{C}$ to yield crude 4-bromo- $N$-phenylaniline. The crude product was isolated by column chromatography with $2 \%$ EtOAc in hexanes to afford the title compound as a white solid (40 $\mathrm{mg}, 49 \%)$. Characterization data match those of previously reported literature. ${ }^{5}$

${ }^{1}$ H NMR: (400 MHz, Chloroform- $d$ ) $\delta 7.40-7.33(\mathrm{~m}, 2 \mathrm{H}), 7.33-7.26(\mathrm{~m}, 2 \mathrm{H}), 7.12-7.04(\mathrm{~m}, 2 \mathrm{H}), 7.02-6.92$ $(\mathrm{m}, 3 \mathrm{H}), 5.67(\mathrm{~s}, 1 \mathrm{H})$.

${ }^{13}$ C NMR: $\left(101 \mathrm{MHz}, \mathrm{CDCl}_{3}\right) \delta 142.5,142.5,132.3,129.6,121.8,119.1,118.4,112.7$.

HRMS-ESI (m/z): $(\mathrm{m} / \mathrm{z})$ : for $\mathrm{C}_{12} \mathrm{H}_{10} \mathrm{BrN}$ [M+H'] : calcd: 248.0075 , found: 248.0068

\section{3 - $N$-Methyl- $N$-phenylaniline}<smiles>CN(c1ccccc1)c1ccccc1</smiles>
The reaction was performed according to the general procedure but at double the concentration. $\mathrm{N}$ Methylaniline ( $64 \mathrm{mg}, 0.60 \mathrm{mmol}$ ) with phenylboronic acid $(110 \mathrm{mg}, 0.902 \mathrm{mmol}), \mathrm{Cu}(\mathrm{OAc})_{2} \bullet 2 \mathrm{H}_{2} \mathrm{O}$ $(26 \mathrm{mg}, 0.12 \mathrm{mmol})$, potassium hexafluorophosphate $(55 \mathrm{mg}, 0.30 \mathrm{mmol})$, sodium acetate $(49 \mathrm{mg}$, $0.60 \mathrm{mmol}$ ), and ferrocenium hexafluorophosphate ( $40 \mathrm{mg}, 0.12 \mathrm{mmol})$ were mixed in $\mathrm{MeCN}(3 \mathrm{~mL})$. The reaction was then electrolyzed at $6 \mathrm{~mA}$ for $96.48 \mathrm{mAh}$ at $60{ }^{\circ} \mathrm{C}$ to yield crude $N$-methyl- $N$-phenylaniline. The crude product was isolated by column chromatography with $1 \%$ triethylamine and $2 \%$ EtOAc in hexanes to afford the product as an orange liquid $(71 \mathrm{mg}, 65 \%)$. Characterization data match those of previously reported literature. ${ }^{8}$

${ }^{1}$ H NMR: (400 MHz, $\left.\mathrm{CDCl}_{3}\right)$ d: 7.33-7.28 (m, 4H), 7.07-7.04 (m, 4H), 7.01-6.96 (tt, J = 7.2, 1.1 Hz, 2H), 3.34 (s, $3 \mathrm{H})$.

${ }^{13}$ C NMR: (101 MHz, $\left.\mathrm{CDCl}_{3}\right) \delta: 149.2,129.3,121.4,120.6,40.4$.

HRMS-ESI (m/z): for $\mathrm{C}_{13} \mathrm{H}_{13} \mathrm{~N}$ [M+H'] : calcd: 184.1126 , found 184.1121

\section{4 - $N$-Phenyl- $n$-butylamine}

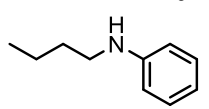

The reaction was performed according to the general procedure but at triple the concentration. $n$ Butylamine $(22 \mathrm{mg}, 0.30 \mathrm{mmol})$ with triethylamine $(18 \mathrm{mg}, 0.18 \mathrm{mmol}), \mathrm{Cu}(\mathrm{OAc})_{2} \bullet 2 \mathrm{H}_{2} \mathrm{O}(39 \mathrm{mg}$, $0.18 \mathrm{mmol})$, potassium hexafluorophosphate $(55 \mathrm{mg}, 0.30 \mathrm{mmol})$, sodium acetate $(49 \mathrm{mg}, 0.60$ $\mathrm{mmol})$, and ferrocenium hexafluorophosphate $(60 \mathrm{mg}, 0.18 \mathrm{mmol})$ were mixed in $\mathrm{MeCN}(3 \mathrm{~mL})$. The reaction was then electrolyzed at $6 \mathrm{~mA}$ for $32.16 \mathrm{mAh}$ at $60{ }^{\circ} \mathrm{C}$ to yield crude $N$-phenyl- $n$-butylamine. The crude product was isolated by column chromatography with $1 \%$ triethylamine and $2 \%$ EtOAc in hexanes to afford the product as a slightly yellow liquid (32 $\mathrm{mg}, 71 \%$ ). Characterization data match those of previously reported literature. ${ }^{5}$

${ }^{1}$ H NMR: $\left(400 \mathrm{MHz}, \mathrm{CDCl}_{3}\right)$ 8: $7.23-7.14(\mathrm{~m}, 2 \mathrm{H}), 6.74-6.66(\mathrm{~m}, 1 \mathrm{H}), 6.65-6.58(\mathrm{~m}, 2 \mathrm{H}), 3.60(\mathrm{~s}, 1 \mathrm{H}), 3.13(\mathrm{t}$, $J=7.1 \mathrm{~Hz}, 2 \mathrm{H}), 1.68-1.57(\mathrm{~m}, 2 \mathrm{H}), 1.53-1.38(\mathrm{~m}, 2 \mathrm{H}), 0.98(\mathrm{t}, J=7.3 \mathrm{~Hz}, 3 \mathrm{H})$.

${ }^{13}$ C NMR: (101 MHz, $\left.\mathrm{CDCl}_{3}\right) \delta: 148.7,129.3,117.2,112.8,43.8,31.8,20.5,14.1$.

HRMS-ESI $(\mathrm{m} / \mathrm{z})$ : for $\mathrm{C}_{10} \mathrm{H}_{15} \mathrm{~N}\left[\mathrm{M}+\mathrm{H}^{+}\right]$: calcd: 150.1283 , found 150.1274

\section{5 - N-Cyclohexylaniline}




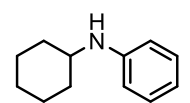

The general procedure described above was applied to the reaction of cyclohexylamine ( $30 \mathrm{mg}, 0.30$ mmol) with phenylboronic acid (55 mg, $0.45 \mathrm{mmol})$. The reaction was then electrolyzed at $3 \mathrm{~mA}$ for $32.16 \mathrm{mAh}$ at $40{ }^{\circ} \mathrm{C}$ to yield crude $\mathrm{N}$-cyclohexylaniline. The crude product was isolated by column chromatography with $5 \%$ EtOAc, $1 \% \mathrm{NEt}_{3}$ in hexanes to afford the product as a white solid (33 $\mathrm{mg}, 63 \%$ ). Characterization data match those of previously reported literature. ${ }^{8}$

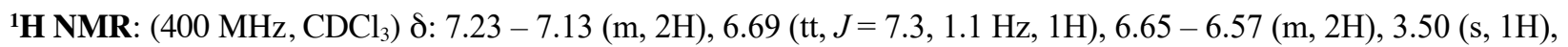
$3.28(\mathrm{tt}, J=10.2,3.8 \mathrm{~Hz}, 1 \mathrm{H}), 2.15-2.00(\mathrm{~m}, 2 \mathrm{H}), 1.79(\mathrm{ddt}, J=11.1,4.2,2.6 \mathrm{~Hz}, 2 \mathrm{H}), 1.73-1.62(\mathrm{~m}, 1 \mathrm{H}), 1.52-$ $1.33(\mathrm{~m}, 2 \mathrm{H}), 1.33-1.11(\mathrm{~m}, 3 \mathrm{H})$.

${ }^{13}$ C NMR: $\left(101 \mathrm{MHz}, \mathrm{CDCl}_{3}\right) \delta: 147.5,129.4,117.0,113.3,51.8,33.6,26.1,25.2$

HRMS-ESI (m/z): for $\mathrm{C}_{12} \mathrm{H}_{17} \mathrm{~N}\left[\mathrm{M}+\mathrm{H}^{+}\right]$: calcd: 176.1439 , found 176.1431

\section{6 - (R)- $N$-(1-Phenylethyl)aniline}

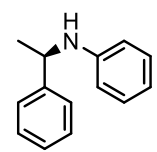

The general procedure described above was applied to the reaction of $(R)-1$-phenylethan-1-amine $(36 \mathrm{mg}$, $0.30 \mathrm{mmol})$ with phenylboronic acid $(55 \mathrm{mg}, 0.45 \mathrm{mmol})$. The reaction was then electrolyzed at $6 \mathrm{~mA}$ for $32.16 \mathrm{mAh}$ at $60^{\circ} \mathrm{C}$ to yield crude $(R)-N$-(1-phenylethyl)aniline. The crude product was isolated by column chromatography with $2 \%$ EtOAc in hexanes to afford the product as a slightly orange liquid (34 $\mathrm{mg}, 57 \%)$. Characterization data match those of previously reported literature. ${ }^{9}$

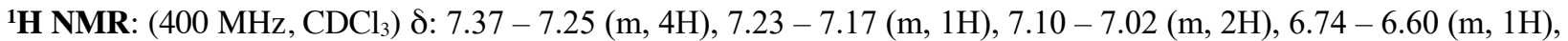
$6.49(\mathrm{dt}, J=7.8,1.1 \mathrm{~Hz}, 2 \mathrm{H}), 4.46(\mathrm{~d}, J=6.7 \mathrm{~Hz}, 1 \mathrm{H}), 3.99(\mathrm{~s}, 1 \mathrm{H}), 1.49(\mathrm{~d}, J=6.7 \mathrm{~Hz}, 3 \mathrm{H})$.

${ }^{13}$ C NMR: (101 MHz, $\left.\mathrm{CDCl}_{3}\right) \delta: 147.4,145.3,129.2,128.8,127.0,126.0,117.4,113.4,53.6,25.1$

HRMS-ESI (m/z): for $\mathrm{C}_{14} \mathrm{H}_{15} \mathrm{~N}\left[\mathrm{M}+\mathrm{H}^{+}\right]$: calcd: 198.1283 , found 198.1275

HPLC: Chiralpak AD-H Column; detected at 220 and $254 \mathrm{~nm}$; hexanes $/ \mathrm{PrOH}=99 / 1$; flow $=1.0 \mathrm{~mL} / \mathrm{min}$; Retention time: $10.91 \mathrm{~min}$.

\section{7 - Methyl phenyl-L-valinate}<smiles>COC(=O)C(Nc1ccccc1)C(C)C</smiles>

The general procedure described above was applied to the reaction of methyl-L-valinate ( $39 \mathrm{mg}$, $0.30 \mathrm{mmol})$ with phenylboronic acid $(55 \mathrm{mg}, 0.45 \mathrm{mmol})$. The reaction was then electrolyzed at 3 $\mathrm{mA}$ for $32.12 \mathrm{mAh}$ at $40{ }^{\circ} \mathrm{C}$ to yield crude methyl phenyl-L-valinate. The crude product was isolated by column chromatography with $10 \%$ EtOAc in hexanes to afford the title compound as colorless liquid (22 $\mathrm{mg}, 36 \%)$. Characterization data match those of previously reported literature. ${ }^{10}$

${ }^{1}$ H NMR: (400 MHz, Chloroform- $d$ ) $\delta 7.21-7.12(\mathrm{~m}, 2 \mathrm{H}), 6.74(\mathrm{tt}, J=7.3,1.1 \mathrm{~Hz}, 1 \mathrm{H}), 6.64$ (dd, $J=8.6,1.1 \mathrm{~Hz}$, $2 \mathrm{H}), 4.12(\mathrm{~d}, J=7.9 \mathrm{~Hz}, 1 \mathrm{H}), 3.88(\mathrm{dd}, J=8.6,5.8 \mathrm{~Hz}, 1 \mathrm{H}), 3.71(\mathrm{~s}, 3 \mathrm{H}), 2.12(\mathrm{dqd}, J=6.9,6.9,5.9 \mathrm{~Hz}, 1 \mathrm{H}), 1.04$ (dd, $J=13.0,6.8 \mathrm{~Hz}, 6 \mathrm{H})$.

${ }^{13}$ C NMR: $\left(101 \mathrm{MHz}, \mathrm{CDCl}_{3}\right) \delta 174.3,147.4,129.4,118.4,113.7,62.6,52.0,31.7,19.2,18.8$.

HRMS-ESI $(\mathrm{m} / \mathrm{z})$ : for $\mathrm{C}_{12} \mathrm{H}_{17} \mathrm{NO}_{2}$ [M+H'] : calcd: 208.1338, found: 208.1333

HPLC: Chiralpak AD-H Column; detected at 220 and $254 \mathrm{~nm}$; hexanes $/ \mathrm{PrOH}=95 / 5$; flow $=0.5 \mathrm{~mL} / \mathrm{min}$; Retention time: $10.14 \mathrm{~min}$.

\section{8 - tert-Butyl 4-phenylpiperazine-1-carboxylate}

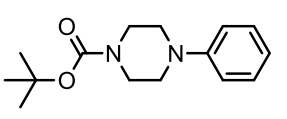

The general procedure described above was applied to the reaction of tert-butyl piperazine-1carboxylate (58 $\mathrm{mg}, 0.31 \mathrm{mmol})$ with phenylboronic acid $(55 \mathrm{mg}, 0.45 \mathrm{mmol})$. The reaction was then electrolyzed at $3 \mathrm{~mA}$ for $56.28 \mathrm{mAh}$ at $60^{\circ} \mathrm{C}$ to yield crude tert-butyl 4-

phenylpiperazine-1-carboxylate. The crude product was isolated by column chromatography with $15 \%$ EtOAc in hexanes to afford the title compound as a white solid $(29 \mathrm{mg}, 36 \%)$. Characterization data match those of previously reported literature. ${ }^{11}$

${ }^{1}$ H NMR: (400 MHz, Chloroform- $d$ ) $\delta 7.31-7.24(\mathrm{~m}, 2 \mathrm{H}), 6.96-6.92(\mathrm{~m}, 2 \mathrm{H}), 6.92-6.87(\mathrm{~m}, 1 \mathrm{H}), 3.63-3.53$ $(\mathrm{m}, 4 \mathrm{H}), 3.18-3.07(\mathrm{~m}, 4 \mathrm{H}), 1.49(\mathrm{~s}, 9 \mathrm{H})$.

${ }^{13}$ C NMR: (101 MHz, $\left.\mathrm{CDCl}_{3}\right) \delta$ 154.9, 151.4, 129.3, 120.4, 116.8, 80.0, 49.6, 44.0 (br), 43.5 (br), 28.6.

HRMS-ESI (m/z): for $\mathrm{C}_{15} \mathrm{H}_{22} \mathrm{~N}_{2} \mathrm{O}_{2}\left[\mathrm{M}+\mathrm{H}^{+}\right]$: calcd: 263.1759 , found: 263.1755

\section{9 - 1-Phenylpiperidine}




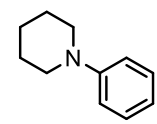

The general procedure described above was applied to the reaction of piperidine $(70 . \mathrm{mg}, 0.30 \mathrm{mmol})$ with phenylboronic acid $(55 \mathrm{mg}, 0.45 \mathrm{mmol})$. Triethylamine was not added. The reaction was then electrolyzed at $3 \mathrm{~mA}$ for $32.16 \mathrm{mAh}$ at $60^{\circ} \mathrm{C}$ to yield crude 1-phenylpiperidine. The crude was isolated by column chromatography with $2 \%$ EtOAc in hexanes to afford the product as a slightly yellow liquid (10 mg, $15 \%)$. Characterization data match those of previously reported literature. ${ }^{11}$

${ }^{1}$ H NMR: (400 MHz, Chloroform- $d$ ) $87.33-7.17(\mathrm{~m}, 2 \mathrm{H}), 7.02-6.92(\mathrm{~m}, 2 \mathrm{H}), 6.83(\mathrm{tt}, \mathrm{J}=7.3,1.1 \mathrm{~Hz}, 1 \mathrm{H}), 3.22-$ $3.11(\mathrm{~m}, 4 \mathrm{H}), 1.77-1.68(\mathrm{~m}, 4 \mathrm{H}), 1.64-1.56(\mathrm{~m}, 2 \mathrm{H})$.

${ }^{13}$ C NMR: $\left(101 \mathrm{MHz}, \mathrm{CDCl}_{3}\right) \delta 152.4,129.1,119.3,116.7,50.8,26.0,24.5$.

HRMS-ESI (m/z): for $\mathrm{C}_{11} \mathrm{H}_{15} \mathrm{~N}$ [M+H'] : calcd: 162.1283 , found: 162.1273

\section{0 - 1-Phenylimidazole}<smiles></smiles>

The general procedure described above was applied to the reaction of imidazole $(20 . \mathrm{mg}, 0.30 \mathrm{mmol})$ with phenylboronic acid $(55 \mathrm{mg}, 0.45 \mathrm{mmol})$. The reaction was then electrolyzed at $6 \mathrm{~mA}$ for $32.16 \mathrm{mAh}$ at $60{ }^{\circ} \mathrm{C}$ to yield crude 1-phenylimmidazole. The crude product was washed with aq. EDTA and brine and isolated by column chromatography with EtOAc to afford the product as a slightly yellow liquid (23 $\mathrm{mg}, 55 \%)$. Characterization data match those of previously reported literature. ${ }^{12}$

${ }^{1}$ H NMR: $\left(400 \mathrm{MHz}, \mathrm{CDCl}_{3}\right.$ ) $\delta: 7.77$ (s, br, 1H), 7.45 - 7.35 (m, 2H), 7.33 - 7.23 (m, 3H), 7.20 (s, br, 1H), 7.15 7.09 (s, br, 1H).

${ }^{13}$ C NMR: $\left(101 \mathrm{MHz}, \mathrm{CDCl}_{3}\right) \delta: 137.4,135.6,130.5,129.9,127.5,121.5,118.3$.

HRMS-ESI (m/z): for $\mathrm{C}_{9} \mathrm{H}_{8} \mathrm{~N}_{2}\left[\mathrm{M}+\mathrm{H}^{+}\right]$: calcd: 145.0766 , found: 145.0755

\section{1 - $N$-Phenylpyridin-2-amine}

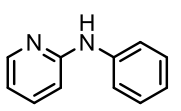

The general procedure described above was applied to the reaction of 2-aminopyridine ( $28 \mathrm{mg}, 0.30$ $\mathrm{mmol}$ ), with triethylamine ( $3 \mathrm{mg}, 0.03 \mathrm{mmol})$, and with phenylboronic acid $(55 \mathrm{mg}, 0.45 \mathrm{mmol})$. The reaction was then electrolyzed at $3 \mathrm{~mA}$ for $32.16 \mathrm{mAh}$ at $40^{\circ} \mathrm{C}$ to yield crude $N$-phenylpyridin-2-amine.

The crude product was isolated by column chromatography with $10 \%$ EtOAc in hexanes to afford the product as a white solid (29 mg, 56\%). Characterization data match those of previously reported literature. ${ }^{8}$

'H NMR: (400 MHz, $\mathrm{CDCl}_{3}$ ) $\delta: 8.21$ (ddd, $\left.J=5.0,2.0,0.9 \mathrm{~Hz}, 1 \mathrm{H}\right), 7.49$ (ddd, $\left.J=8.4,7.2,1.9 \mathrm{~Hz}, 1 \mathrm{H}\right), 7.33$ (m, 4H), $7.17-6.99(\mathrm{~m}, 1 \mathrm{H}), 6.88(\mathrm{dt}, J=8.4,1.0 \mathrm{~Hz}, 2 \mathrm{H}), 6.73(\mathrm{ddd}, J=7.2,5.0,0.9 \mathrm{~Hz}, 1 \mathrm{H})$.

${ }^{13}$ C NMR: (101 MHz, $\left.\mathrm{CDCl}_{3}\right) \delta: 156.2,148.6,140.6,137.8,129.4,123.0,120.5,115.2,108.3$

HRMS-ESI (m/z): for $\mathrm{C}_{11} \mathrm{H}_{10} \mathrm{~N}_{2}\left[\mathrm{M}+\mathrm{H}^{+}\right]$: calcd: 171.0922 , found: 171.0910

\section{2 - $N$-Phenylpyridin-3-amine}<smiles>c1ccc(Nc2ccncc2)cc1</smiles>

The general procedure described above was applied to the reaction of 3-aminopyridine ( $28 \mathrm{mg}, 0.30$ $\mathrm{mmol})$ with phenylboronic acid $(55 \mathrm{mg}, 0.45 \mathrm{mmol})$. The reaction was then electrolyzed at $6 \mathrm{~mA}$ for $32.16 \mathrm{mAh}$ at $60{ }^{\circ} \mathrm{C}$ to yield crude $N$-phenylpyridin-3-amine. The crude product was isolated by column chromatography with $40 \%$ EtOAc in hexanes to afford the product as a white solid (22 $\mathrm{mg}, 44 \%$ ). Characterization data match those of previously reported literature. ${ }^{13}$

${ }^{1}$ H NMR: $\left(400 \mathrm{MHz}, \mathrm{CDCl}_{3}\right) \delta: 8.39(\mathrm{~s}, 1 \mathrm{H}), 8.16(\mathrm{~d}, J=4.6 \mathrm{~Hz}, 1 \mathrm{H}), 7.41(\mathrm{ddd}, J=8.3,2.8,1.4 \mathrm{~Hz}, 1 \mathrm{H}), 7.30(\mathrm{dd}$, $J=8.6,7.3 \mathrm{~Hz}, 2 \mathrm{H}), 7.17$ (dd, $J=8.3,4.6 \mathrm{~Hz}, 1 \mathrm{H}), 7.12-7.06(\mathrm{~m}, 2 \mathrm{H}), 6.99$ (td, $J=7.3,1.2 \mathrm{~Hz}, 1 \mathrm{H}), 5.92(\mathrm{~s}, 1 \mathrm{H})$.

${ }^{13}$ C NMR: $\left(101 \mathrm{MHz}, \mathrm{CDCl}_{3}\right) \delta: 142.1,142.0,140.3,140.0,129.7,123.8,123.5,122.1,118.4$

HRMS-ESI (m/z): for $\mathrm{C}_{11} \mathrm{H}_{10} \mathrm{~N}_{2}\left[\mathrm{M}+\mathrm{H}^{+}\right]$: calcd: 171.0922 , found: 171.0909

\section{3 - Diphenylether}<smiles>c1ccc(Oc2ccccc2)cc1</smiles>

The reaction was performed according to the general procedure but at double the concentration. Phenol

(56 mg, $0.60 \mathrm{mmol})$ with triethylamine $(12 \mathrm{mg}, 0.12 \mathrm{mmol})$, phenylboronic acid (110 mg, $0.90 \mathrm{mmol})$, $\mathrm{Cu}(\mathrm{OAc})_{2} \bullet 2 \mathrm{H}_{2} \mathrm{O}(26 \mathrm{mg}, 0.12 \mathrm{mmol})$, potassium hexafluorophosphate $(55 \mathrm{mg}, 0.30 \mathrm{mmol})$, sodium acetate (49 $\mathrm{mg}$, $0.60 \mathrm{mmol})$, and ferrocenium hexafluorophosphate $(40 \mathrm{mg}, 0.12 \mathrm{mmol})$ were mixed in $\mathrm{MeCN}(3 \mathrm{~mL})$. The reaction was then electrolyzed at $6 \mathrm{~mA}$ for $64.32 \mathrm{mAh}$ at $60^{\circ} \mathrm{C}$ to yield crude diphenylether. The crude product was isolated by column chromatography with hexanes to afford the product as a slightly orange liquid (41 $\mathrm{mg}, 41 \%)$. 
Characterization data match those of previously reported literature. ${ }^{14}$

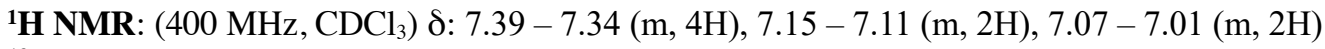

${ }^{13}$ C NMR: $\left(101 \mathrm{MHz}, \mathrm{CDCl}_{3}\right) \delta: 157.4,129.9,123.3,119.0$

HRMS-ESI (m/z): for $\mathrm{C}_{12} \mathrm{H}_{10} \mathrm{O}\left[\mathrm{M}+\mathrm{H}^{+}\right]$: calcd: 171.0810 , found: 171.0805

\section{4 - N-Phenyl-[1,1'-biphenyl]-4-amine}

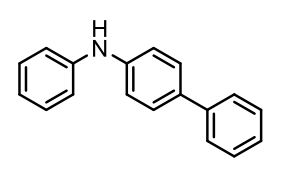

The general procedure described above was applied to the reaction of aniline $(28 \mathrm{mg}, 0.30$ mmol) with [1,1'-biphenyl]-4-ylboronic acid ( $89 \mathrm{mg}, 0.45 \mathrm{mmol})$. The reaction was then electrolyzed at $5 \mathrm{~mA}$ for $32.12 \mathrm{mAh}$ at $60^{\circ} \mathrm{C}$ to yield crude $\mathrm{N}$-phenyl-[1,1'-biphenyl]-4-amine.

The crude product was isolated by column chromatography with $2 \%$ EtOAc in hexanes to afford the title compound as a white solid $(71 \mathrm{mg}, 95 \%)$. Characterization data match those of previously reported literature. ${ }^{15}$

${ }^{1}$ H NMR: (400 MHz, Chloroform- $d$ ) $\delta 7.65-7.58(\mathrm{~m}, 2 \mathrm{H}), 7.58-7.52(\mathrm{~m}, 2 \mathrm{H}), 7.49-7.42(\mathrm{~m}, 2 \mathrm{H}), 7.38-7.30$ (m, 3H), $7.24-7.08(\mathrm{~m}, 4 \mathrm{H}), 7.04-6.95(\mathrm{~m}, 1 \mathrm{H}), 5.78(\mathrm{~s}, 1 \mathrm{H})$.

${ }^{13}$ C NMR: $\left(101 \mathrm{MHz}, \mathrm{CDCl}_{3}\right) \delta$ 143.0, 142.7, 141.0, 133.8, 129.5, 128.9, 128.1, 126.7, 126.7, 121.4, 118.2, 117.9. HRMS-ESI (m/z): for $\mathrm{C}_{18} \mathrm{H}_{15} \mathrm{~N}$ [M+H']: calcd: 246.1282 , found: 246.1278

\section{5 - 4-(tert-Butyl)- $N$-phenylaniline}

The general procedure described above was applied to the reaction of aniline $(29 \mathrm{mg}, 0.31 \mathrm{mmol})$
with (4-(tert-butyl)phenyl)boronic acid (80. $\mathrm{mg}, 0.45 \mathrm{mmol})$. The reaction was then electrolyzed
at $3 \mathrm{~mA}$ for $56.28 \mathrm{mAh}$ at $60^{\circ} \mathrm{C}$ to yield crude 4 -(tert-butyl)- $N$-phenylaniline. The crude product was isolated by column chromatography with $2 \%$ EtOAc in hexanes to afford the title compound as an off-white solid (37 mg, 53\%). Characterization data match those of previously reported literature. ${ }^{16}$

${ }^{1}$ H NMR: (400 MHz, Chloroform- $d$ ) $\delta 7.25-7.12$ (m, 4H), 6.95 (m, 4H), 6.80 (t, J= 7.3 Hz, 1H), 5.53 (s, 1H), 1.23 (d, $J=2.3 \mathrm{~Hz}, 9 \mathrm{H})$.

${ }^{13}$ C NMR: (101 MHz, $\left.\mathrm{CDCl}_{3}\right) \delta$ 144.3, 143.8, 140.4, 129.4, 126.3, 120.5, 118.3, 117.2, 34.3, 31.6.

HRMS-ESI (m/z): for $\mathrm{C}_{16} \mathrm{H}_{19} \mathrm{~N}$ [M+H'] : calcd: 226.1595, found: 226.1590

\section{6 - 4-Methoxy- $N$-phenylaniline}<smiles>COc1ccc(Nc2ccccc2)cc1</smiles>

The general procedure described above was applied to the reaction of aniline $(28 \mathrm{mg}, 0.30 \mathrm{mmol})$ with (4-methoxyphenyl)boronic acid (68 $\mathrm{mg}, 0.45 \mathrm{mmol})$ and 1,1-dimethylferrocene (13 $\mathrm{mg}$, $0.060 \mathrm{mmol}$ ) was added to the reaction instead of $\mathrm{Fc}^{+} \mathrm{PF}_{6}$. The reaction was then electrolyzed at 3 $\mathrm{mA}$ for $42 \mathrm{mAh}$ at $60^{\circ} \mathrm{C}$ (for this reaction the cathode was only submerged to a depth of $2 \mathrm{~mm}$ ) to yield crude 4methoxy- $N$-phenylaniline. The crude product was isolated by column chromatography with $2 \%$ EtOAc in hexanes to afford the title compound as an off-white solid (19 mg, 31\%). Characterization data match those of previously reported literature. ${ }^{15}$

${ }^{1}$ H NMR: (400 MHz, Chloroform- $d$ ) $\delta 7.25$ - 7.18 (m, 2H), 7.12 - 7.04 (m, 2H), 6.95 - 6.90 (m, 2H), 6.90 - 6.81 $(\mathrm{m}, 3 \mathrm{H}), 5.49(\mathrm{~s}, 1 \mathrm{H}), 3.81(\mathrm{~s}, 3 \mathrm{H})$.

${ }^{13}$ C NMR: $\left(101 \mathrm{MHz}, \mathrm{CDCl}_{3}\right) \delta 155.3,145.2,135.7,129.3,122.2,119.6,115.6,114.7,55.6$.

HRMS-ESI (m/z): for $\mathrm{C}_{13} \mathrm{H}_{13} \mathrm{NO}\left[\mathrm{M}+\mathrm{H}^{+}\right.$]: calcd: 200.1075 , found: 200.1071

\section{7 - 2-Methyl- $N$-phenylaniline}

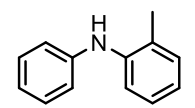

The general procedure described above was applied to the reaction of aniline $(29 \mathrm{mg}, 0.31 \mathrm{mmol})$ with $o$-tolylboronic acid $(61 \mathrm{mg}, 0.45 \mathrm{mmol})$. The reaction was then electrolyzed at $3 \mathrm{~mA}$ for 32.12 $\mathrm{mAh}$ at $40{ }^{\circ} \mathrm{C}$ to yield crude 2-methyl- $N$-phenylaniline. The crude product was isolated by column chromatography with $2 \%$ EtOAc in hexanes to afford the title compound as an orange liquid (22 $\mathrm{mg}, 39 \%)$. Characterization data match those of previously reported literature. ${ }^{2}$

${ }^{1}$ H NMR: (400 MHz, Chloroform- $d$ ) $\delta 7.20-7.10(\mathrm{~m}, 4 \mathrm{H}), 7.06(\mathrm{t}, J=7.7 \mathrm{~Hz}, 1 \mathrm{H}), 6.93-6.79(\mathrm{~m}, 4 \mathrm{H}), 5.29(\mathrm{~s}$, $1 \mathrm{H}), 2.18(\mathrm{~s}, 3 \mathrm{H})$.

${ }^{13}$ C NMR: $\left(101 \mathrm{MHz}, \mathrm{CDCl}_{3}\right) \delta 144.1,141.3,131.1,129.4,128.4,126.9,122.1,120.6,118.9,117.6,18.0$. 
HRMS-ESI (m/z): for $\mathrm{C}_{13} \mathrm{H}_{13} \mathrm{~N}$ [M+H'] : calcd: 184.1126 , found: 184.1123

\section{8 - 2-Phenoxy- $N$-phenylaniline}

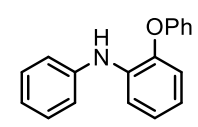

The reaction was performed according to the general procedure but at double the concentration. Aniline $(56 \mathrm{mg}, 0.60 \mathrm{mmol})$, with triethylamine $(6 \mathrm{mg}, 0.06 \mathrm{mmol}), 2$-(phenoxyphenyl)boronic acid (193 mg, $0.902 \mathrm{mmol}), \mathrm{Cu}(\mathrm{OAc})_{2} \bullet 2 \mathrm{H}_{2} \mathrm{O}(26 \mathrm{mg}, 0.12 \mathrm{mmol})$, potassium hexafluorophosphate $(55 \mathrm{mg}$, $0.30 \mathrm{mmol})$, sodium acetate $(98 \mathrm{mg}, 1.2 \mathrm{mmol})$, and ferrocenium hexafluorophosphate $(40 \mathrm{mg}, 0.12 \mathrm{mmol})$ were mixed in $\mathrm{MeCN}(3 \mathrm{ml})$. The reaction was then electrolyzed at $3 \mathrm{~mA}$ for $96.48 \mathrm{mAh}$ at $40{ }^{\circ} \mathrm{C}$ to yield crude 2-phenoxy$N$-phenylaniline. The crude product was isolated by column chromatography with $0 \sim 2 \%$ EtOAc, in hexanes to afford the product as a white solid $(90 \mathrm{mg}, 57 \%)$. Characterization data match those of previously reported literature. ${ }^{17}$

${ }^{1} \mathbf{H}$ NMR: $\left(400 \mathrm{MHz}, \mathrm{CDCl}_{3}\right)$ 8: $7.41(\mathrm{dd}, J=8.1,1.5 \mathrm{~Hz}, 1 \mathrm{H}), 7.39-7.24(\mathrm{~m}, 4 \mathrm{H}), 7.20-7.02(\mathrm{~m}, 6 \mathrm{H}), 7.01-6.92$ (m, 2H), 6.84 (ddd, $J=8.0,7.3,1.5 \mathrm{~Hz}, 1 \mathrm{H}), 6.13(\mathrm{~s}, 1 \mathrm{H})$.

${ }^{13}$ C NMR: (101 MHz, $\left.\mathrm{CDCl}_{3}\right) \delta$ : 157.4, 145.1, 142.3, 135.8, 129.9. 129.4, 124.4, 123.3, 121.8, 120.2, 119.7, 119.2, 118.0, 115.9.

HRMS-ESI (m/z): for $\mathrm{C}_{18} \mathrm{H}_{15} \mathrm{NO}\left[\mathrm{M}+\mathrm{H}^{+}\right]$: calcd: 262.1232 , found: 262.1229

\section{9 - $N$-Phenyl-4-(trifluoromethyl)aniline}

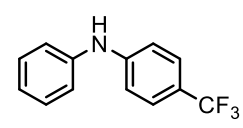

The general procedure described above was applied to the reaction of aniline (29 $\mathrm{mg}, 0.31 \mathrm{mmol})$ with (4-(trifluoromethyl)phenyl)boronic acid $(85 \mathrm{mg}, 0.45 \mathrm{mmol})$. The reaction was then

electrolyzed at $6 \mathrm{~mA}$ for $32.12 \mathrm{mAh}$ at $60^{\circ} \mathrm{C}$ to yield crude $N$-phenyl-4-(trifluoromethyl)aniline.

The crude product was isolated by column chromatography with $2 \%$ EtOAc in hexanes to afford the title compound as an opaque oil (60. $\mathrm{mg}, 83 \%)$. Characterization data match those of previously reported literature. ${ }^{15}$

${ }^{1}$ H NMR: (400 MHz, Chloroform- $d$ ) $\delta 7.53-7.45(\mathrm{~m}, 2 \mathrm{H}), 7.40-7.30(\mathrm{~m}, 2 \mathrm{H}), 7.21-7.14(\mathrm{~m}, 2 \mathrm{H}), 7.13-7.01$ $(\mathrm{m}, 3 \mathrm{H}), 5.91(\mathrm{~s}, 1 \mathrm{H})$.

${ }^{19}$ F NMR: $\left.376 \mathrm{MHz}, \mathrm{CDCl}_{3}\right) \delta-61.4$.

${ }^{13}$ C NMR: (101 MHz, Chloroform- $d$ ) $\delta$ 146.9, 141.3, 129.7, 126.8 (q, $\left.J=3.7 \mathrm{~Hz}\right), 124.2(\mathrm{q}, \mathrm{J}=270.4 \mathrm{~Hz}), 123.1$, $121.8(\mathrm{q}, \mathrm{J}=32.6 \mathrm{~Hz}), 120.2,115.5$.

HRMS-ESI (m/z): for $\mathrm{C}_{13} \mathrm{H}_{10} \mathrm{~F}_{3} \mathrm{~N}$ [M+H'] : calcd: 238.0843 , found: 238.0838

\section{0 - 4-(Phenylamino)benzonitrile}

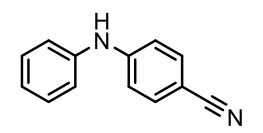

The general procedure described above was applied to the reaction of aniline $(29 \mathrm{mg}, 0.31 \mathrm{mmol})$ and (4-cyanophenyl)boronic acid ( $66 \mathrm{mg}, 0.45 \mathrm{mmol})$. The reaction was then electrolyzed at $5 \mathrm{~mA}$

for $56.28 \mathrm{mAh}$ at $60{ }^{\circ} \mathrm{C}$ to yield crude 4 -(phenylamino)benzonitrile. The crude product was

isolated by column chromatography with triethylamine and $10 \%$ EtOAc in hexanes to afford the product as an orange liquid (32 mg, 53\%). Characterization data match those of previously reported literature. ${ }^{15}$

'H NMR: (400 MHz, Chloroform- $d$ ) $\delta: 7.51-7.44(\mathrm{~m}, 2 \mathrm{H}), 7.39-7.31(\mathrm{~m}, 2 \mathrm{H}), 7.17(\mathrm{dd}, J=8.5,1.0 \mathrm{~Hz}, 2 \mathrm{H})$, $7.15-7.08(\mathrm{~m}, 1 \mathrm{H}), 7.00-6.94(\mathrm{~m}, 2 \mathrm{H}), 6.15(\mathrm{~s}, 1 \mathrm{H})$.

${ }^{13}$ C NMR: (101 MHz, $\left.\mathrm{CDCl}_{3}\right) \delta: 148.1,140.1,133.9,129.7,124.1,121.3,120.1,115.0,101.5$.

HRMS-ESI (m/z): for $\mathrm{C}_{13} \mathrm{H}_{10} \mathrm{~N}_{2}\left[\mathrm{M}+\mathrm{H}^{+}\right]$: calcd: 195.0922, found: 195.0918

\section{1 - 1-(4-(Phenylamino)phenyl)ethan-1-one}

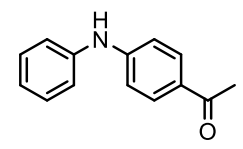

The general procedure described above was applied to the reaction of aniline $(29 \mathrm{mg}, 0.31 \mathrm{mmol})$ with (4-acetylphenyl)boronic acid ( $74 \mathrm{mg}, 0.45 \mathrm{mmol})$. The reaction was then electrolyzed at 3 $\mathrm{mA}$ for $32.12 \mathrm{mAh}$ at $40^{\circ} \mathrm{C}$ to yield crude 1-(4-(phenylamino)phenyl)ethan-1-one. The crude product was isolated by column chromatography with $2 \%$ EtOAc in hexanes to afford the title compound as a white solid $(49 \mathrm{mg}, 76 \%)$. Characterization data match those of previously reported literature. ${ }^{5}$ ${ }^{1}$ H NMR: ${ }^{1} \mathrm{H}$ NMR (400 MHz, Chloroform- $d$ ) $\delta 7.90-7.84(\mathrm{~m}, 2 \mathrm{H}), 7.38-7.31(\mathrm{~m}, 2 \mathrm{H}), 7.22-7.15(\mathrm{~m}, 2 \mathrm{H}), 7.11$ $-7.05(\mathrm{~m}, 1 \mathrm{H}), 7.04-6.97(\mathrm{~m}, 2 \mathrm{H}), 6.29(\mathrm{~s}, 1 \mathrm{H}), 2.53(\mathrm{~s}, 3 \mathrm{H})$.

${ }^{13}$ C NMR: (101 MHz, $\left.\mathrm{CDCl}_{3}\right) \delta$ 196.6, 148.6, 140.7, 130.7, 129.6, 129.0, 123.4, 120.8, 114.5, 26.3.

HRMS-ESI (m/z): for $\mathrm{C}_{14} \mathrm{H}_{13} \mathrm{NO}\left[\mathrm{M}+\mathrm{H}^{+}\right.$]: calcd: 212.1075 , found: 212.1067 


\section{2 - Methyl 4-(phenylamino)benzoate}

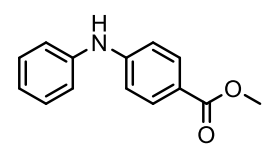

The general procedure described above was applied to the reaction of aniline $(28 \mathrm{mg}, 0.30$ mmol) with (4-(methoxycarbonyl)phenyl)boronic acid $(81 \mathrm{mg}, 0.45 \mathrm{mmol})$. The reaction was then electrolyzed at $3 \mathrm{~mA}$ for $32.12 \mathrm{mAh}$ at $40{ }^{\circ} \mathrm{C}$ to yield crude methyl $4-$

(phenylamino)benzoate. The crude product was isolated by column chromatography with $5 \%$ EtOAc in hexanes to afford the title compound as a white solid $(59 \mathrm{mg}, 82 \%)$. Characterization data match those of previously reported literature. ${ }^{5}$

'H NMR: (400 MHz, Chloroform- $d$ ) $\delta 7.92(\mathrm{~d}, J=8.8 \mathrm{~Hz}, 2 \mathrm{H}), 7.34(\mathrm{t}, J=7.9 \mathrm{~Hz}, 2 \mathrm{H}), 7.17(\mathrm{~d}, J=7.6 \mathrm{~Hz}, 2 \mathrm{H})$, $7.07(\mathrm{t}, J=7.4 \mathrm{~Hz}, 1 \mathrm{H}), 6.99(\mathrm{~d}, J=8.8 \mathrm{~Hz}, 2 \mathrm{H}), 6.13(\mathrm{~s}, 1 \mathrm{H}), 3.88(\mathrm{~s}, 3 \mathrm{H})$.

${ }^{13}$ C NMR: $\left(101 \mathrm{MHz}, \mathrm{CDCl}_{3}\right) \delta 167.1,148.2,141.0,131.6,129.6,123.2,121.1,120.5,114.7,51.8$.

HRMS-ESI (m/z): for $\mathrm{C}_{14} \mathrm{H}_{13} \mathrm{NO}_{2}\left[\mathrm{M}+\mathrm{H}^{+}\right]$: calcd: 228.1024 , found: 228.1017

\section{3 - $N$-Phenyl-3,5-bis(trifluoromethyl)aniline}

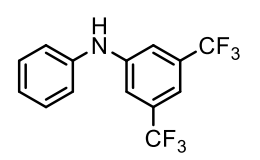

The general procedure described above was applied to the reaction of aniline $(28 \mathrm{mg}, 0.30 \mathrm{mmol})$ with (3,5-bis(trifluoromethyl)phenyl)boronic acid $(116 \mathrm{mg}, 0.450 \mathrm{mmol})$. The reaction was then electrolyzed at $5 \mathrm{~mA}$ for $32.12 \mathrm{mAh}$ at $60{ }^{\circ} \mathrm{C}$ to yield crude $\mathrm{N}$-phenyl-3,5-

bis(trifluoromethyl)aniline. The crude product was isolated by column chromatography with $2 \%$ EtOAc in hexanes to afford the title compound as a white solid $(82 \mathrm{mg}, 88 \%)$. Characterization data match those of previously reported literature. ${ }^{6}$

${ }^{1}$ H NMR: (400 MHz, Chloroform- $d$ ) $\delta 7.44-7.35$ (m, 4H), 7.33 (s, 1H), 7.20 - 7.10 (m, 3H), $5.99(\mathrm{~s}, 1 \mathrm{H})$.

${ }^{19}$ F NMR: $\left(376 \mathrm{MHz}, \mathrm{CDCl}_{3}\right) \delta-63.22$.

${ }^{13}$ C NMR: $\left(101 \mathrm{MHz}, \mathrm{CDCl}_{3}\right) \delta 145.5,140.5,132.9$ (q, $\left.J=33.0 \mathrm{~Hz}\right), 130.0,124.9,122.9$ (q, $\left.J=272.9 \mathrm{~Hz}\right), 120.6$, $115.3(\mathrm{q}, J=4.0 \mathrm{~Hz}), 113.1$ (hept, $J=4.0 \mathrm{~Hz}$ ).

HRMS-ESI $(\mathrm{m} / \mathrm{z})$ : for $\mathrm{C}_{14} \mathrm{H}_{9} \mathrm{~F}_{6} \mathrm{~N}\left[\mathrm{M}+\mathrm{H}^{+}\right]$: calcd: 306.0717 , found: 306.0713

\section{4 - 3,5-Dimethoxy- $N$-phenylaniline}<smiles>COc1cc(Nc2ccccc2)cc(OC)c1</smiles>

The general procedure described above was applied to the reaction of aniline $(29 \mathrm{mg}, 0.31 \mathrm{mmol})$ with (3,5-dimethoxyphenyl)boronic acid $(82 \mathrm{mg}, 0.45 \mathrm{mmol})$. The reaction was then electrolyzed at $3 \mathrm{~mA}$ for $32.12 \mathrm{mAh}$ at $60{ }^{\circ} \mathrm{C}$ to yield crude 3,5 -dimethoxy- $N$-phenylaniline. The crude product was isolated by column chromatography with $2 \%$ EtOAc in hexanes to afford the title compound as a white solid (39 mg, 56\%). Characterization data match those of previously reported literature. ${ }^{5}$ ${ }^{1}$ H NMR: (400 MHz, Chloroform- $d$ ) $\delta 7.36-7.21(\mathrm{~m}, 2 \mathrm{H}), 7.11(\mathrm{~d}, J=7.6 \mathrm{~Hz}, 2 \mathrm{H}), 6.96(\mathrm{t}, J=7.4 \mathrm{~Hz}, 1 \mathrm{H}), 6.25$ (d, $J=2.1 \mathrm{~Hz}, 2 \mathrm{H}), 6.17-6.03(\mathrm{~m}, 1 \mathrm{H}), 5.72(\mathrm{~s}, 1 \mathrm{H}), 3.77(\mathrm{~s}, 6 \mathrm{H})$.

${ }^{13}$ C NMR: $\left(101 \mathrm{MHz}, \mathrm{CDCl}_{3}\right) \delta 161.8,145.1,142.9,129.5,121.6,118.9,95.9,93.1,55.4$.

HRMS-ESI (m/z): for $\mathrm{C}_{14} \mathrm{H}_{15} \mathrm{NO}_{2}\left[\mathrm{M}+\mathrm{H}^{+}\right]$: calcd: 230.1181 , found: 230.1180

\section{5 - 4-Fluoro- $N$-phenylaniline}

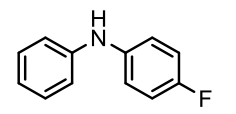

The general procedure described above was applied to the reaction of aniline $(29 \mathrm{mg}, 0.31 \mathrm{mmol})$ with (4-fluorophenyl)boronic acid $(63 \mathrm{mg}, 0.45 \mathrm{mmol})$. The reaction was then electrolyzed at $3 \mathrm{~mA}$ for $32.12 \mathrm{mAh}$ at $60^{\circ} \mathrm{C}$ to yield crude 4 -fluoro- $N$-phenylaniline. The crude product was isolated by column chromatography with $2 \%$ EtOAc in hexanes to afford the title compound as an off-white solid (39 $\mathrm{mg}$, $68 \%)$. Characterization data match those of previously reported literature. ${ }^{5}$

${ }^{1}$ H NMR: (400 MHz, Chloroform- $d$ ) $\delta 7.20-7.12(\mathrm{~m}, 2 \mathrm{H}), 6.99-6.93(\mathrm{~m}, 2 \mathrm{H}), 6.92-6.85(\mathrm{~m}, 4 \mathrm{H}), 6.84-6.77$ $(\mathrm{m}, 1 \mathrm{H}), 5.48(\mathrm{~s}, 1 \mathrm{H})$.

${ }^{19}$ F NMR: ${ }^{19} \mathrm{~F}$ NMR $\left(376 \mathrm{MHz}, \mathrm{CDCl}_{3}\right) \delta-122.00$.

${ }^{13}$ C NMR: (101 MHz, Chloroform- $d$ ) $\delta 158.2(\mathrm{~d}, J=239.8 \mathrm{~Hz}), 144.1,139.0,129.5,120.7,120.7,116.9,116.1(\mathrm{~d}, J$ $=22.5 \mathrm{~Hz})$.

HRMS-ESI (m/z): for $\mathrm{C}_{12} \mathrm{H}_{10} \mathrm{FN}\left[\mathrm{M}+\mathrm{H}^{+}\right]$: calcd: 188.0875 , found: 188.0871

\section{6 - 4-bromo- $N$-phenylaniline}


(yr

The general procedure described above was applied to the reaction of aniline ( $28 \mathrm{mg}, 0.30 \mathrm{mmol})$ with (4-bromophenyl)boronic acid $(90 . \mathrm{mg}, 0.45 \mathrm{mmol}$ ). The reaction was then electrolyzed at 3

$\mathrm{mA}$ for $32.12 \mathrm{mAh}$ at $40{ }^{\circ} \mathrm{C}$ to yield crude 4-bromo- $\mathrm{N}$-phenylaniline. The crude product was

isolated by column chromatography with $2 \%$ EtOAc in hexanes to afford the title compound as a white solid (45 $\mathrm{mg}, 60 \%)$. Characterization data match those of previously reported literature. ${ }^{5}$

${ }^{1}$ H NMR: (400 MHz, Chloroform- $d$ ) $\delta 7.29-7.23(\mathrm{~m}, 2 \mathrm{H}), 7.23-7.15(\mathrm{~m}, 2 \mathrm{H}), 7.00-6.94(\mathrm{~m}, 2 \mathrm{H}), 6.91-6.81$ $(\mathrm{m}, 3 \mathrm{H}), 5.58(\mathrm{~s}, 1 \mathrm{H})$.

${ }^{13}$ C NMR: (101 MHz, $\left.\mathrm{CDCl}_{3}\right) \delta$ 142.6, 142.5, 132.3, 129.6, 121.8, 119.1, 118.4, 112.7.

HRMS-ESI (m/z): for $\mathrm{C}_{12} \mathrm{H}_{10} \mathrm{BrN}$ [M+H']: calcd: 248.0075 , found: 248.0068

\section{7 - 3-bromo- $N$-phenylaniline}<smiles>Brc1cccc(Nc2ccccc2)c1</smiles>

The general procedure described above was applied to the reaction of aniline ( $28 \mathrm{mg}, 0.30 \mathrm{mmol})$ with (3-bromophenyl)boronic acid $(90 . \mathrm{mg}, 0.45 \mathrm{mmol}$ ). The reaction was then electrolyzed at 3 $\mathrm{mA}$ for $32.12 \mathrm{mAh}$ at $60{ }^{\circ} \mathrm{C}$ to yield crude 3-bromo- $\mathrm{N}$-phenylaniline. The crude product was isolated by column chromatography with $2 \%$ EtOAc in hexanes to afford the title compound as a white solid (44 $\mathrm{mg}, 59 \%)$. Characterization data match those of previously reported literature. ${ }^{18}$

${ }^{1}$ H NMR: (400 MHz, Chloroform- $d$ ) $\delta 7.35-7.28(\mathrm{~m}, 2 \mathrm{H}), 7.21(\mathrm{t}, J=2.0 \mathrm{~Hz}, 1 \mathrm{H}), 7.11(\mathrm{~m}, 3 \mathrm{H}), 7.06-6.98(\mathrm{~m}$, 2H), 6.95 (ddd, $J=8.1,2.3,1.0 \mathrm{~Hz}, 1 \mathrm{H}), 5.70$ (s, 1H).

${ }^{13}$ C NMR: $\left(101 \mathrm{MHz}, \mathrm{CDCl}_{3}\right) \delta 145.1,142.0,130.7,129.6,123.5,123.2,122.3,119.7,119.1,115.7$.

HRMS-ESI (m/z): for $\mathrm{C}_{12} \mathrm{H}_{10} \mathrm{BrN}$ [M+H+]: calcd: 248.0069, found: 248.0069

\section{$\underline{\text { Substrate Scope Limitations }}$}

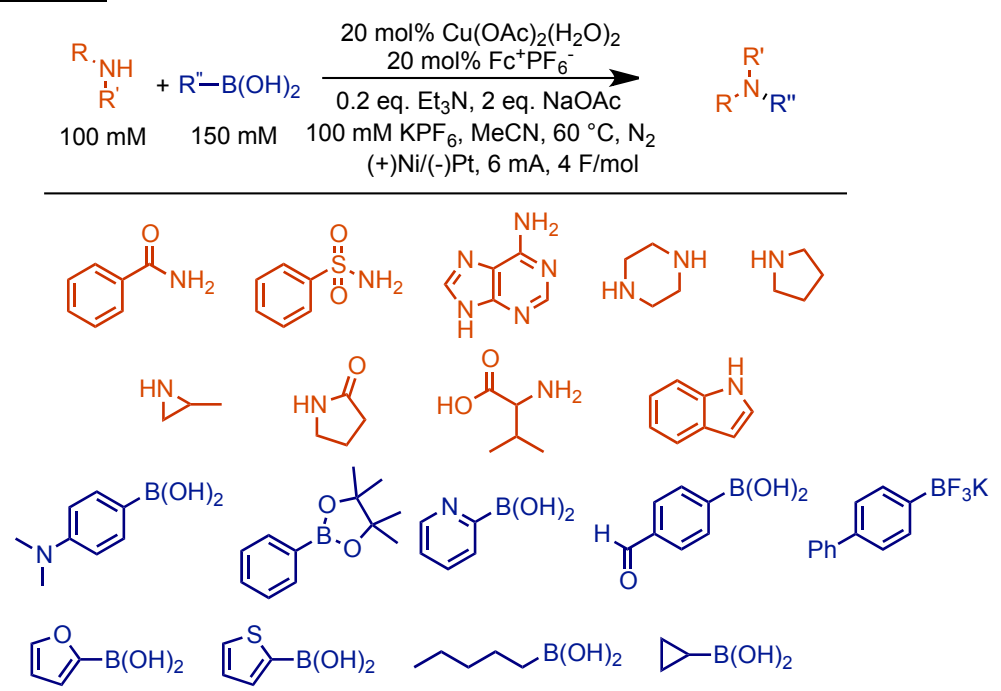

Figure S4. Representative list of substrates that failed to generate $>10 \%$ product yield under standard conditions. Yields based on GC analysis using dodecane as an internal standard.

\section{Additional Studies on Reaction Development}

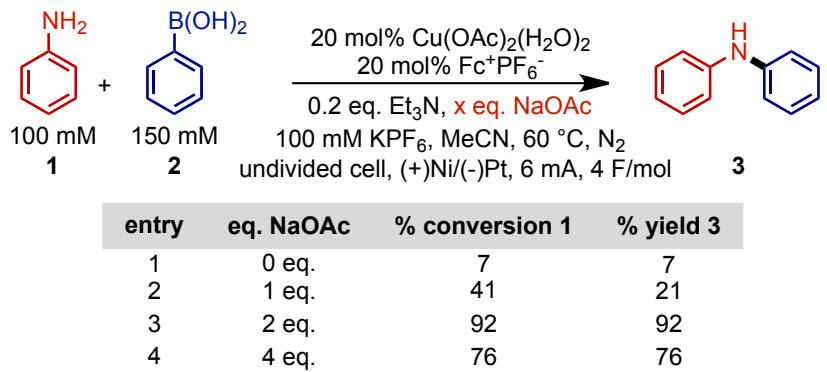


Figure S5. Evaluation of $\mathrm{NaOAc}$ loading in electrochemical reactions.

\begin{tabular}{|c|c|c|c|c|}
\hline $100 \mathrm{mM}$ & $\underbrace{\mathrm{B}(\mathrm{OH})_{2}}_{\substack{R \\
\text { undi }}}$ & $\begin{array}{l}20 \mathrm{~mol} \% \mathrm{Cu}( \\
20 \mathrm{~mol} \% \mathrm{red} \\
.2 \mathrm{eq} . \mathrm{Et} \\
3\end{array}$ & $\begin{array}{l}\mathrm{Ac})_{2}\left(\mathrm{H}_{2} \mathrm{O}\right)_{2} \\
\text { ox mediator } \\
\underset{\text { eq. } \mathrm{NaOAC}}{\longrightarrow} \\
\mathrm{MeCN}, \mathrm{N}_{2} \\
\mathrm{Ni} /(-) \mathrm{Pt}, 3 \mathrm{~mA} \\
\text { or } 7 \mathrm{~F} / \mathrm{mol}\end{array}$ & $26 / 32$ \\
\hline Entry & $R$ group $E$ & Eq. NaOAc & $\%$ Conversion & $\%$ yield $26 / 32$ \\
\hline $1^{\mathrm{a}}$ & OMe (26) & 1 & 38 & 10 \\
\hline $2^{a}$ & OMe (26) & 2 & 45 & 31 \\
\hline $3^{a}$ & OMe (26) & 4 & 66 & 22 \\
\hline $4^{\mathrm{b}}$ & $\mathrm{CO}_{2} \mathrm{Me} \mathrm{(32)}$ & 1 & 38 & 30 \\
\hline $5^{b}$ & $\mathrm{CO}_{2} \mathrm{Me}(32)$ & 2 & 93 & 80 \\
\hline $6^{\mathrm{b}}$ & $\mathrm{CO}_{2} \mathrm{Me}(32)$ & 4 & 85 & 60 \\
\hline
\end{tabular}

aat $60^{\circ} \mathrm{C}$ for $7 \mathrm{~F} / \mathrm{mol}$, bat $40^{\circ} \mathrm{C}$ for $4 \mathrm{~F} / \mathrm{mol}$

Figure S6. Evaluation of acetate loading for reactions of electron rich and electron poor arylboronic acids.

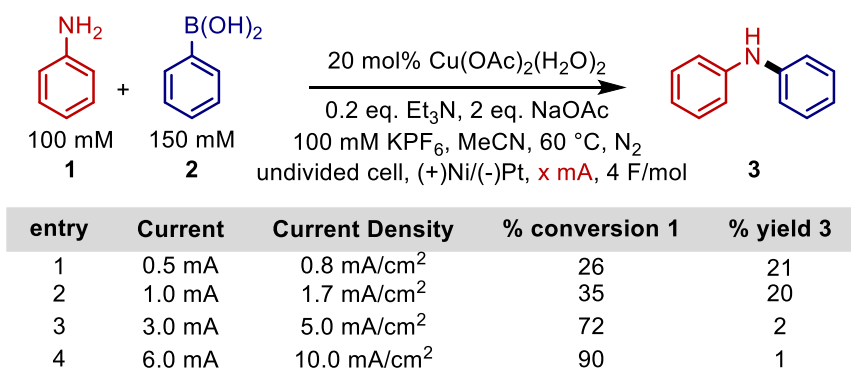

Figure S7. Evaluation of current density on reactions without mediator.

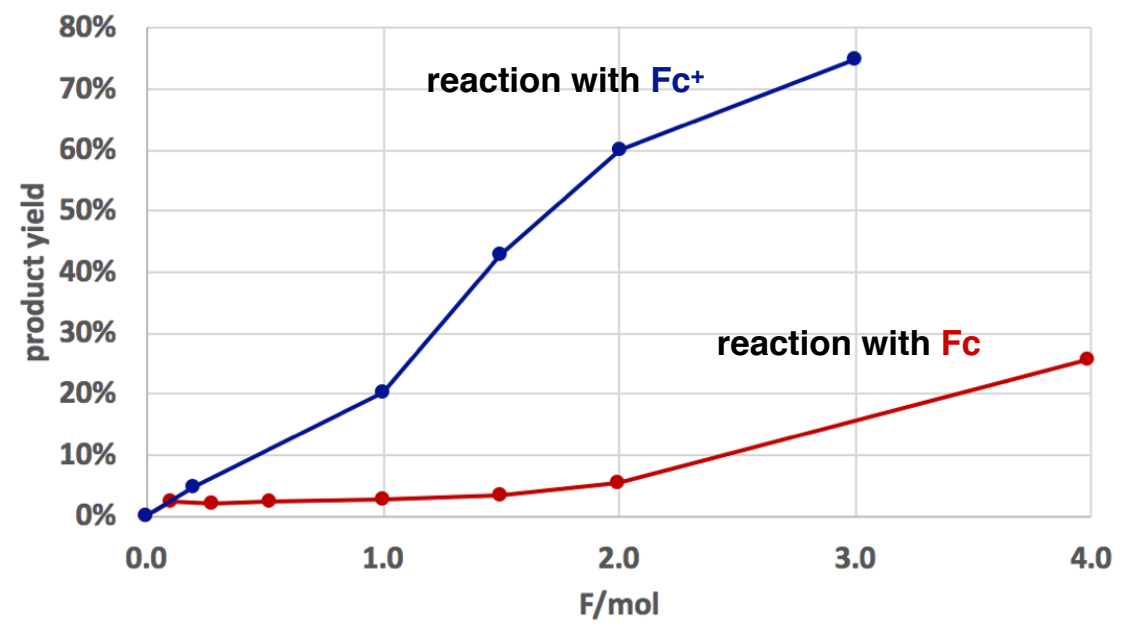

Figure S8. Evaluation of yield as a function of time for reactions with $\mathrm{Fc}$ or $\mathrm{Fc}^{+}$mediators. 


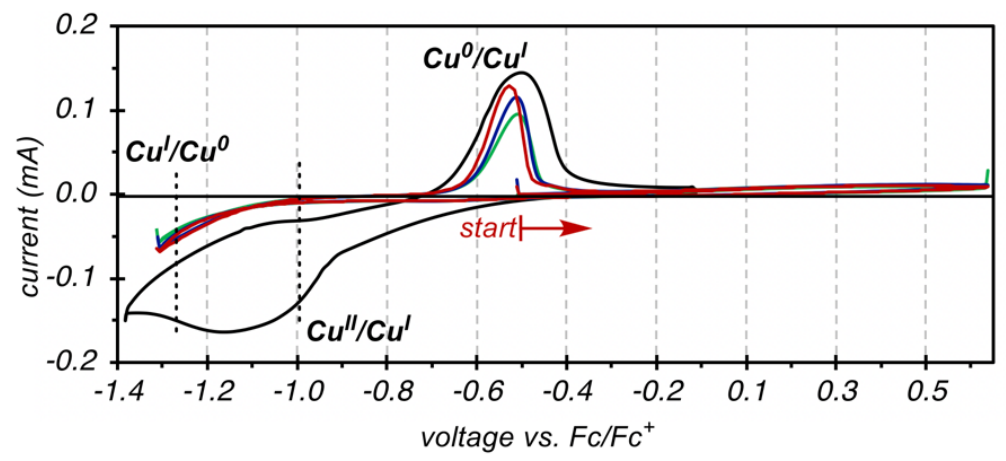

Figure S9. Overlaid $\mathrm{CVs}$ of $\mathrm{Cu}^{\mathrm{II}}(\mathrm{OAc})_{2}$ (black trace, $\left.20 \mathrm{mM}\right), \mathrm{Cu}^{\mathrm{I}}(\mathrm{OAc})$ (green, $\left.20 \mathrm{mM}\right), \mathrm{Cu}^{\mathrm{I}}(\mathrm{OAc})$ with 1 equiv $\mathrm{NaOAc}$ (blue trace), $\mathrm{Cu}^{\mathrm{I}}(\mathrm{OAc})$ in a saturated solution of $\mathrm{NaOAc}$ (red trace). $\mathrm{CV}$ conditions: $0.1 \mathrm{M} \mathrm{KPF}_{6}$ in $\mathrm{MeCN}_{\text {; }}$ $100 \mathrm{mV} / \mathrm{s}$ scan rate; room temperature; glassy carbon working electrode (WE) and Pt counter electrode (CE). CV scans were performed from $-0.4 \mathrm{~V}$ to $+0.65 \mathrm{~V}$ to $-1.3 \mathrm{~V}$ and back to $+0.65 \mathrm{~V}$. Results show no oxidation of $\mathrm{Cu}^{\mathrm{I}}$ with or without added acetate.

\section{$\underline{\text { References }}$}

(1) Connelly, N. G.; Geiger, W. E. Chemical Redox Agents for Organometallic Chemistry. Chem. Rev. 1996, 96 (2), 877-910. https://doi.org/10.1021/cr940053x.

(2) Raghuvanshi, D. S.; Gupta, A. K.; Singh, K. N. Nickel-Mediated N-Arylation with Arylboronic Acids: An Avenue to Chan-Lam Coupling. Org. Lett. 2012, 14 (17), 4326-4329. https://doi.org/10.1021/ol3021836.

(3) Ichitsuka, T.; Takahashi, I.; Koumura, N.; Sato, K.; Kobayashi, S. Continuous Synthesis of Aryl Amines from Phenols Utilizing Integrated Packed-Bed Flow Systems. Angew. Chemie - Int.Ed.2020, 59 (37), 15891-15896. https://doi.org/10.1002/anie.202005109.

(4) Rao, B.; Zeng, X. Aminocyanation by the Addition of N-CN Bonds to Arynes: Chemoselective Synthesis of 1,2-Bifunctional Aminobenzonitriles. Org. Lett. 2014, 16 (1), 314-317. https://doi.org/10.1021/ol403346x.

(5) Suárez-Pantiga, S.; Hernández-Ruiz, R.; Virumbrales, C.; Pedrosa, M. R.; Sanz, R. Reductive MolybdenumCatalyzed Direct Amination of Boronic Acids with Nitro Compounds. Angew. Chemie - Int. Ed. 2019, 58 (7), 2129-2133. https://doi.org/10.1002/anie.201812806.

(6) Schwarz, J. L.; Schäfers, F.; Tlahuext-Aca, A.; Lückemeier, L.; Glorius, F. Diastereoselective Allylation of Aldehydes by Dual Photoredox and Chromium Catalysis. J. Am. Chem. Soc. 2018, 140 (40), 12705-12709. https://doi.org/10.1021/jacs.8b08052.

(7) Girard, S. A.; Hu, X.; Knauber, T.; Zhou, F.; Simon, M. O.; Deng, G. J.; Li, C. J. Pd-Catalyzed Synthesis of Aryl Amines via Oxidative Aromatization of Cyclic Ketones and Amines with Molecular Oxygen. Org. Lett. 2012, 14 (21), 5606-5609. https://doi.org/10.1021/ol3027279.

(8) Shen, Q.; Ogata, T.; Hartwig, J. F. Highly Reactive, General and Long-Lived Catalysts for PalladiumCatalyzed Amination of Heteroaryl and Aryl Chlorides, Bromides, and Iodides: Scope and Structure-Activity Relationships. J. Am. Chem. Soc. 2008, 130 (20), 6586-6596. https://doi.org/10.1021/ja077074w.

(9) Mewald, M.; Oestreich, M. Illuminating the Mechanism of the Borane-Catalyzed Hydrosilylation of Imines with Both an Axially Chiral Borane and Silane. Chem. - A Eur. J. 2012, 18 (44), 14079-14084. https://doi.org/10.1002/chem.201202693.

(10) Sharma, K. K.; Sharma, S.; Kudwal, A.; Jain, R. Room Temperature N-Arylation of Amino Acids and Peptides Using Copper(i) and $\beta$-Diketone. Org. Biomol. Chem. 2015, 13 (16), 4637-4641. https://doi.org/10.1039/c5ob00288e.

(11) Zhang, Q.; Hitoshio, K.; Saito, H.; Shimokawa, J.; Yorimitsu, H. Copper-Catalyzed Electrophilic Amination of Alkoxyarylsilanes. European J. Org. Chem. 2020, 2020 (26), 4018-4021. https://doi.org/10.1002/ejoc.202000562.

(12) Gair, J. J.; Grey, R. L.; Giroux, S.; Brodney, M. A. Palladium Catalyzed Hydrodefluorination of Fluoro(Hetero)Arenes. Org. Lett. 2019, 21 (7), 2482-2487. https://doi.org/10.1021/acs.orglett.9b00889.

(13) Zhu, L.; Ye, Y. M.; Shao, L. X. Well-Defined NHC-Pd(II)-Im (NHC=N-Heterocyclic Carbene; Im=1Methylimidazole) Complex Catalyzed C-N Coupling of Primary Amines with Aryl Chlorides. Tetrahedron 2012, 68 (10), 2414-2420. https://doi.org/10.1016/j.tet.2012.01.008.

(14) Sahoo, B.; Surkus, A. E.; Pohl, M. M.; Radnik, J.; Schneider, M.; Bachmann, S.; Scalone, M.; Junge, K.; 
Beller, M. A Biomass-Derived Non-Noble Cobalt Catalyst for Selective Hydrodehalogenation of Alkyl and (Hetero)Aryl Halides. Angew. Chemie - Int. Ed. 2017, 56 (37), 11242-11247. https://doi.org/10.1002/anie.201702478.

(15) Hanley, P. S.; Clark, T. P.; Krasovskiy, A. L.; Ober, M. S.; O’Brien, J. P.; Staton, T. S. Palladium- and NickelCatalyzed Amination of Aryl Fluorosulfonates. ACS Catal. 2016, 6 (6), 3515-3519. https://doi.org/10.1021/acscatal.6b00865.

(16) Hajra, A.; Wei, Y.; Yoshikai, N. Palladium-Catalyzed Aerobic Dehydrogenative Aromatization of Cyclohexanone Imines to Arylamines. Org. Lett. 2012, 14 (21), 5488-5491. https://doi.org/10.1021/ol302568b.

(17) Chen, H.; Han, J.; Wang, L. Intramolecular Aryl Migration of Diaryliodonium Salts: Access to Ortho-Iodo Diaryl Ethers. Angew. Chemie - Int.Ed. 2018,57 (38), 12313-12317. https://doi.org/10.1002/anie.201806405.

(18) Yu, J.; Wang, Y.; Zhang, P.; Wu, J. Direct Amination of Phenols under Metal-Free Conditions. Synlett 2013, 24 (11), 1448-1454. https://doi.org/10.1055/s-0033-1338703. 
$3-{ }^{1} \mathrm{H}$ NMR

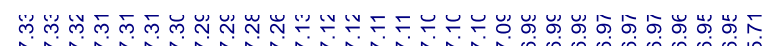<smiles>c1ccc(Nc2ccccc2)cc1</smiles>

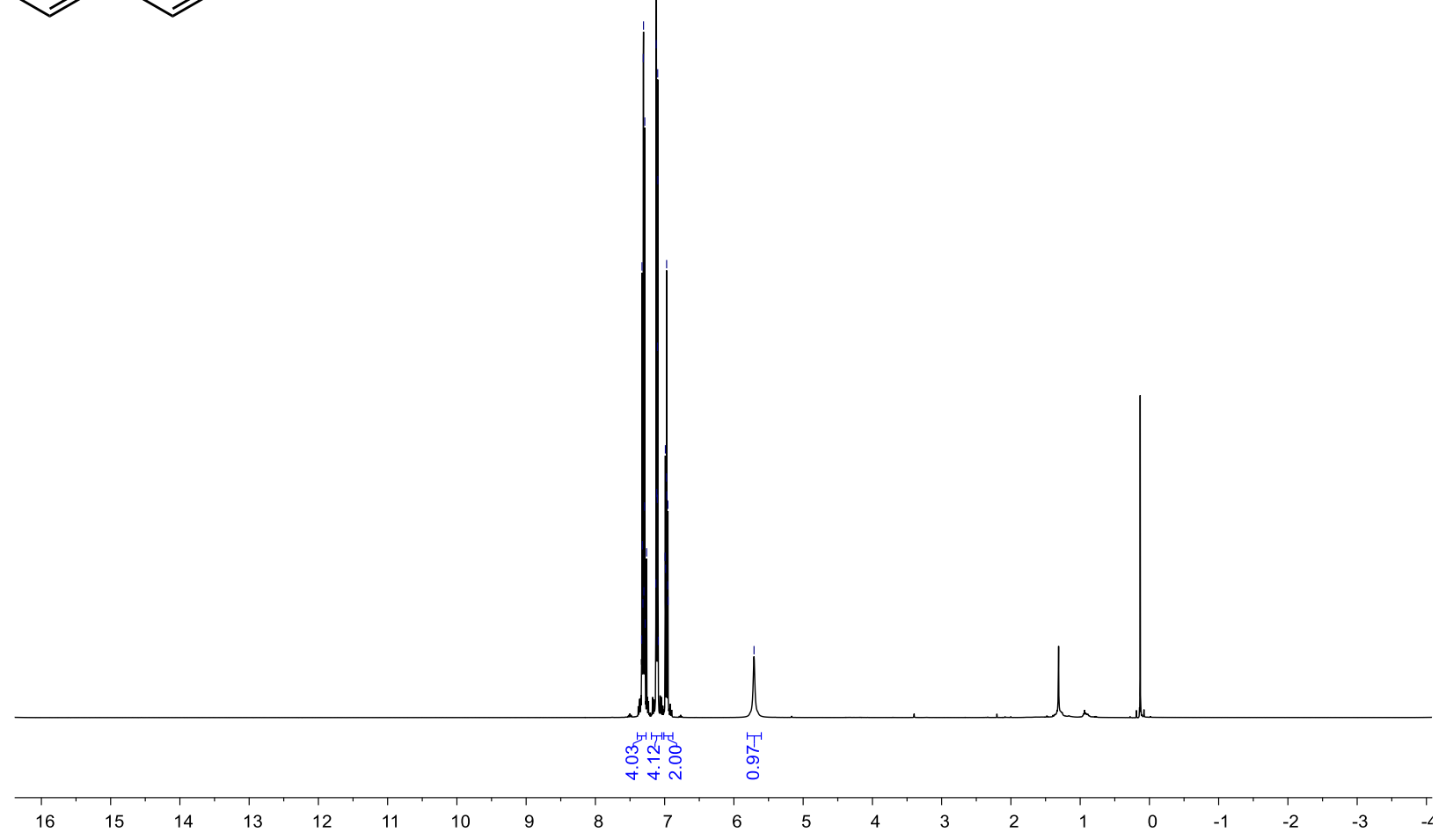

$3-{ }^{13}$ C NMR
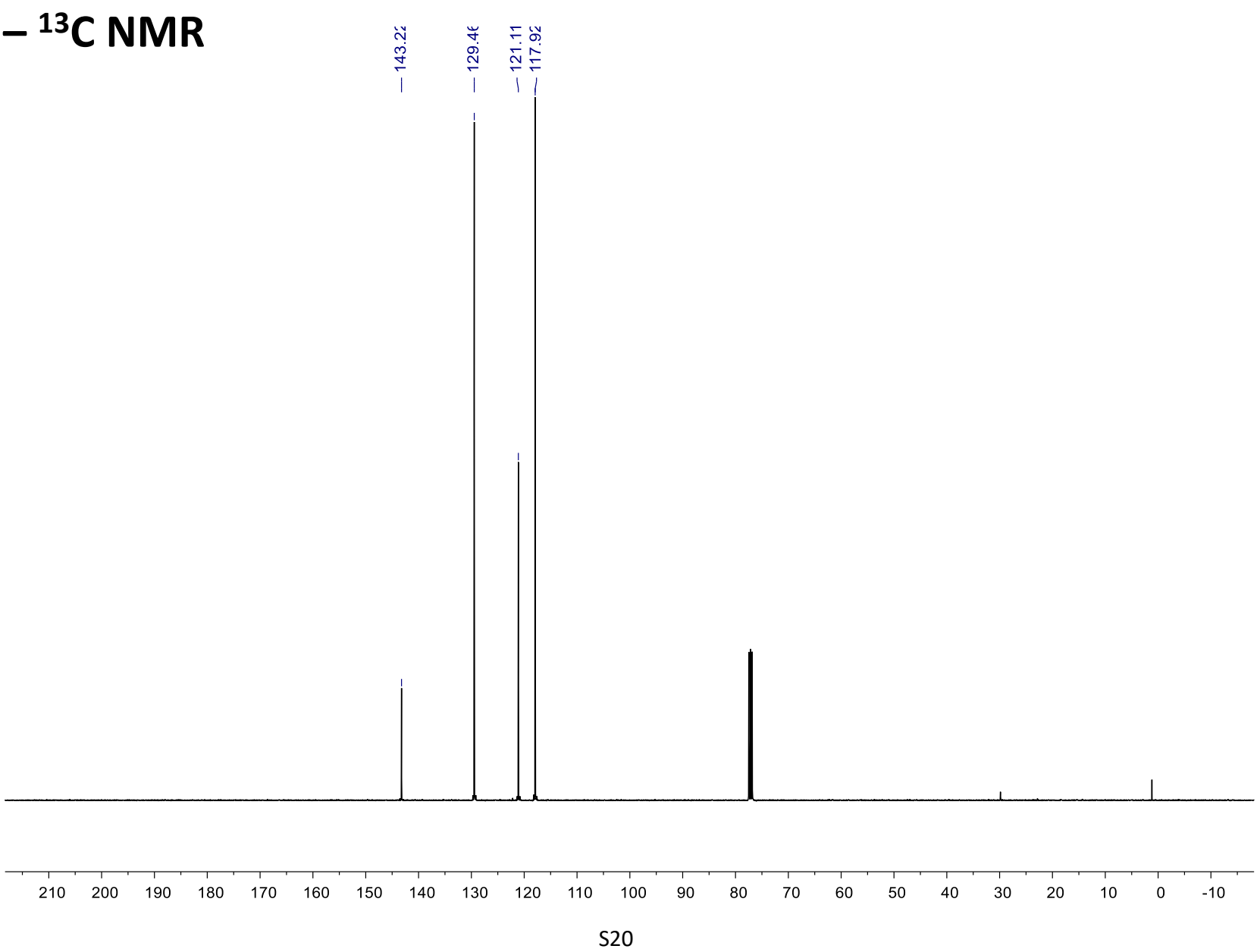


\section{$4-{ }^{1} \mathrm{H} N M R$}

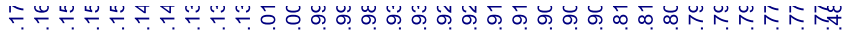

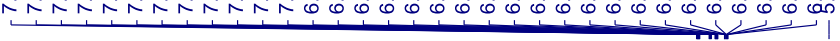<smiles>Cc1ccc(Nc2ccccc2)cc1</smiles>

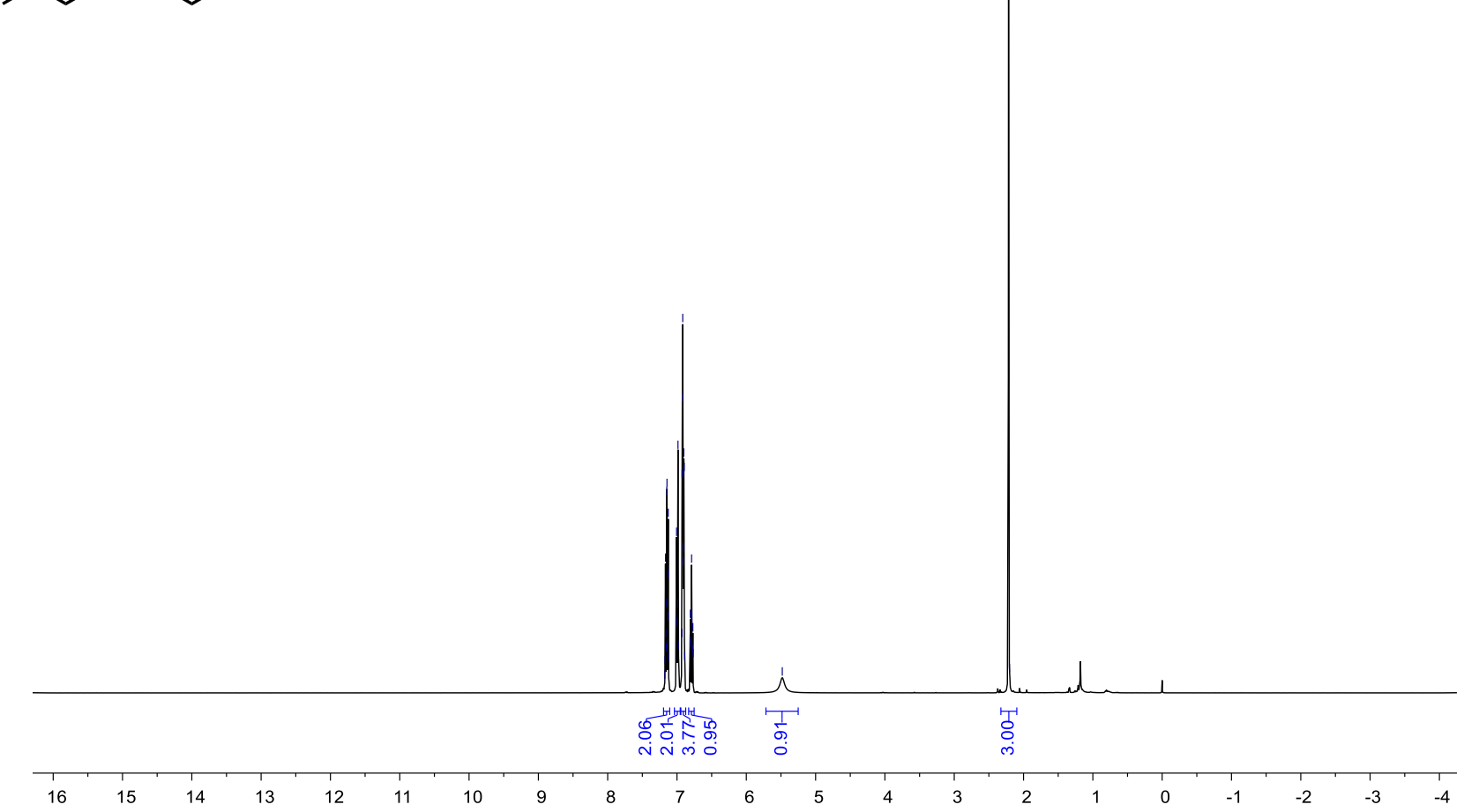

$4-{ }^{13}$ C NMR

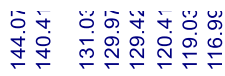

1 i 


\section{$5-{ }^{1} \mathrm{H}$ NMR}<smiles>Cc1cc(C)c(Nc2ccccc2)c(C)c1</smiles>

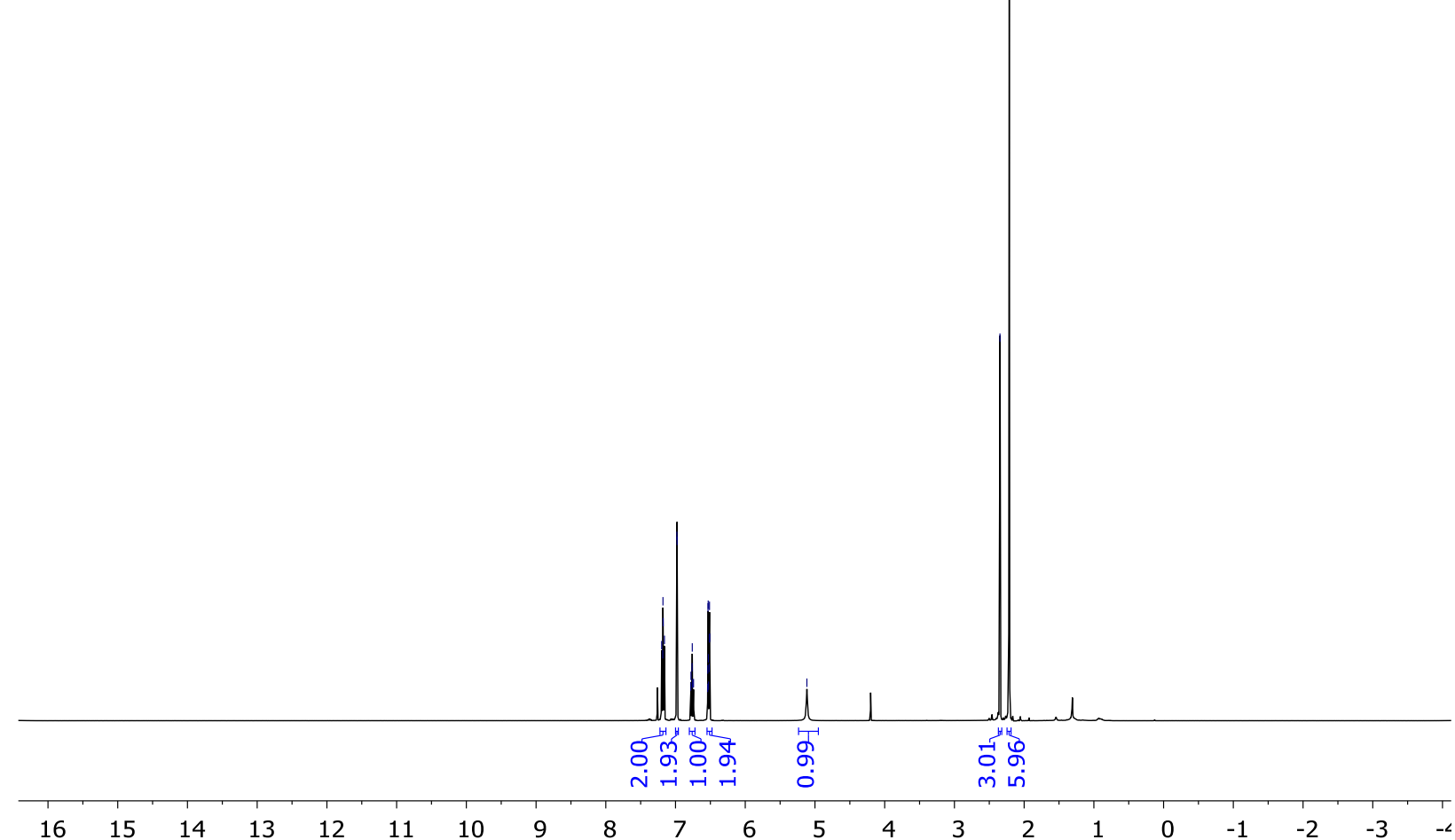

\section{$5-{ }^{13}$ C NMR}




\section{6 - ${ }^{1} \mathrm{H}$ NMR}

พ̣ సุ

N r r

$\mathrm{H}^{+}$

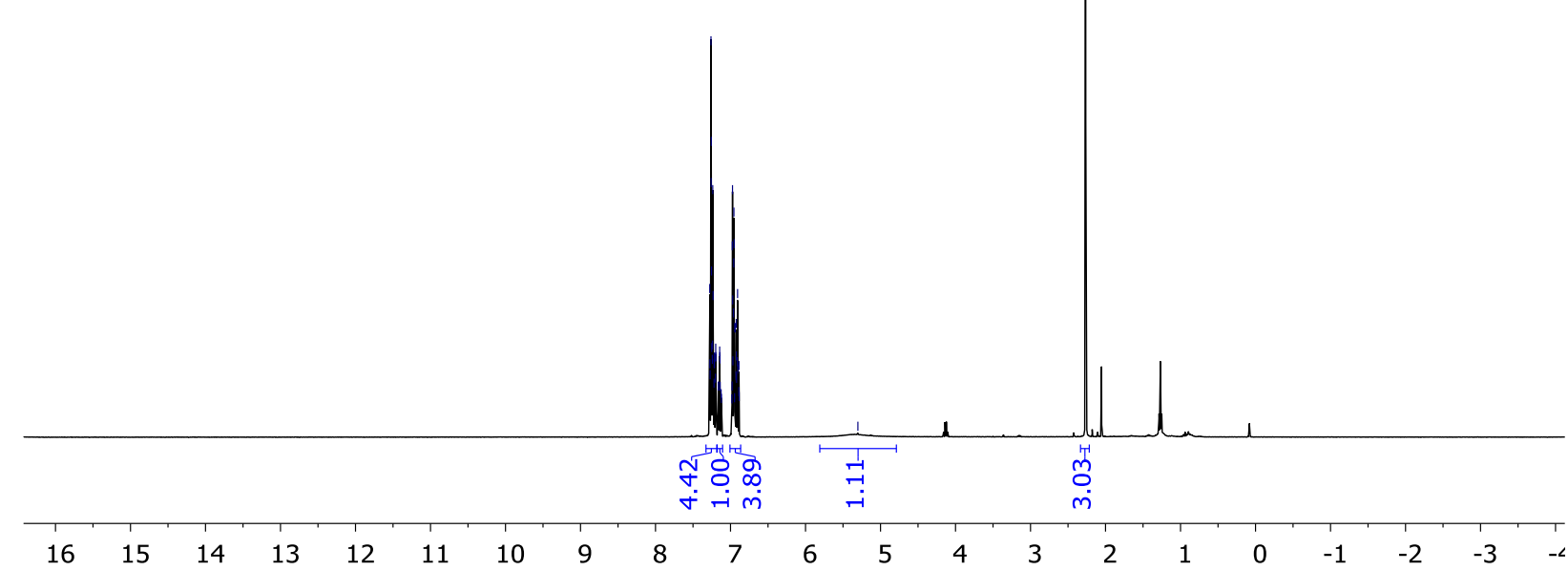

$6-{ }^{13}$ C NMR

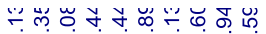

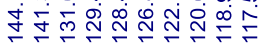

11 il 1, 
$7-{ }^{1} \mathrm{H}$ NMR<smiles>N#Cc1ccccc1Nc1ccccc1</smiles>

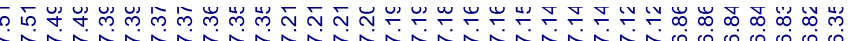

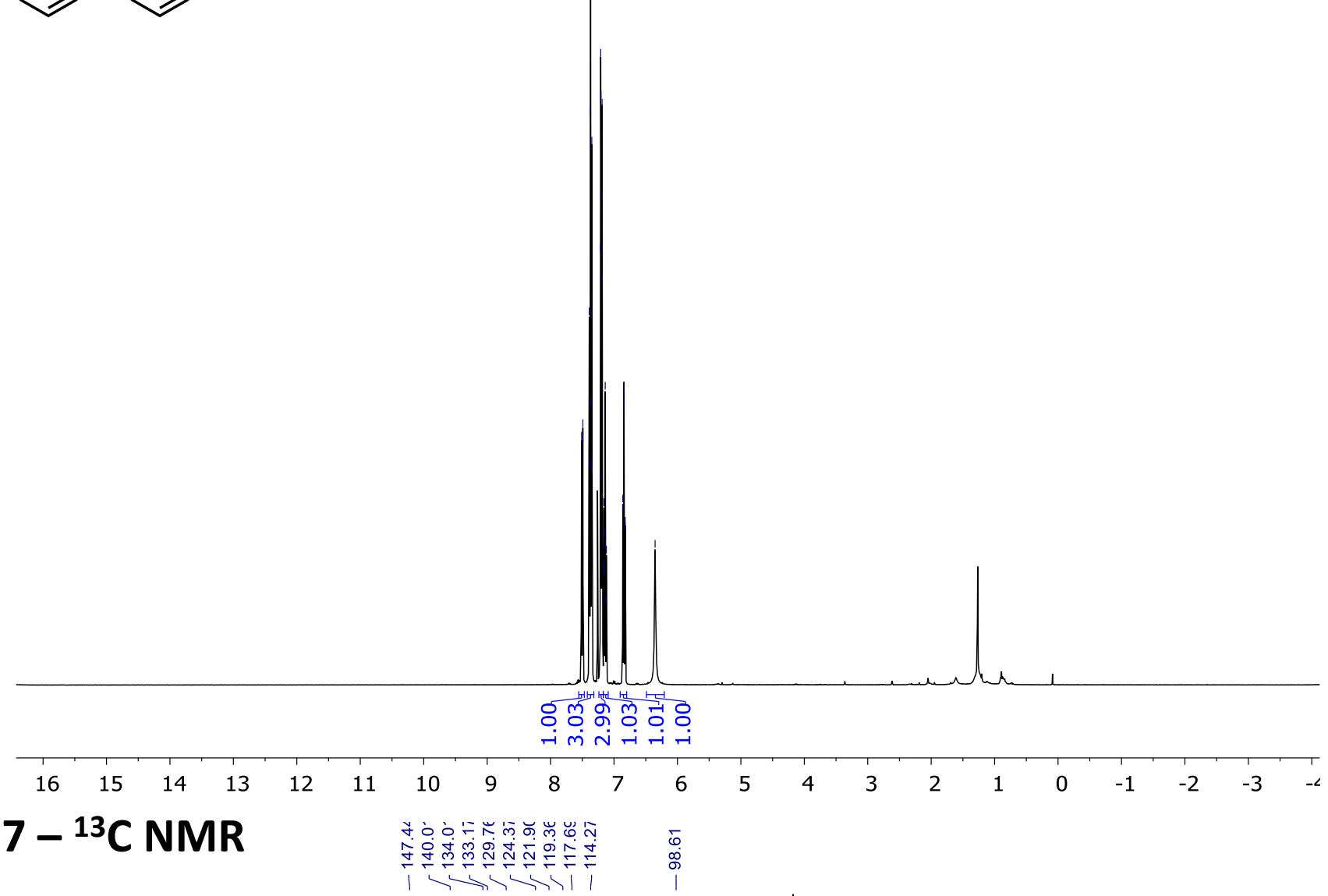

$7-{ }^{13}$ C NMR

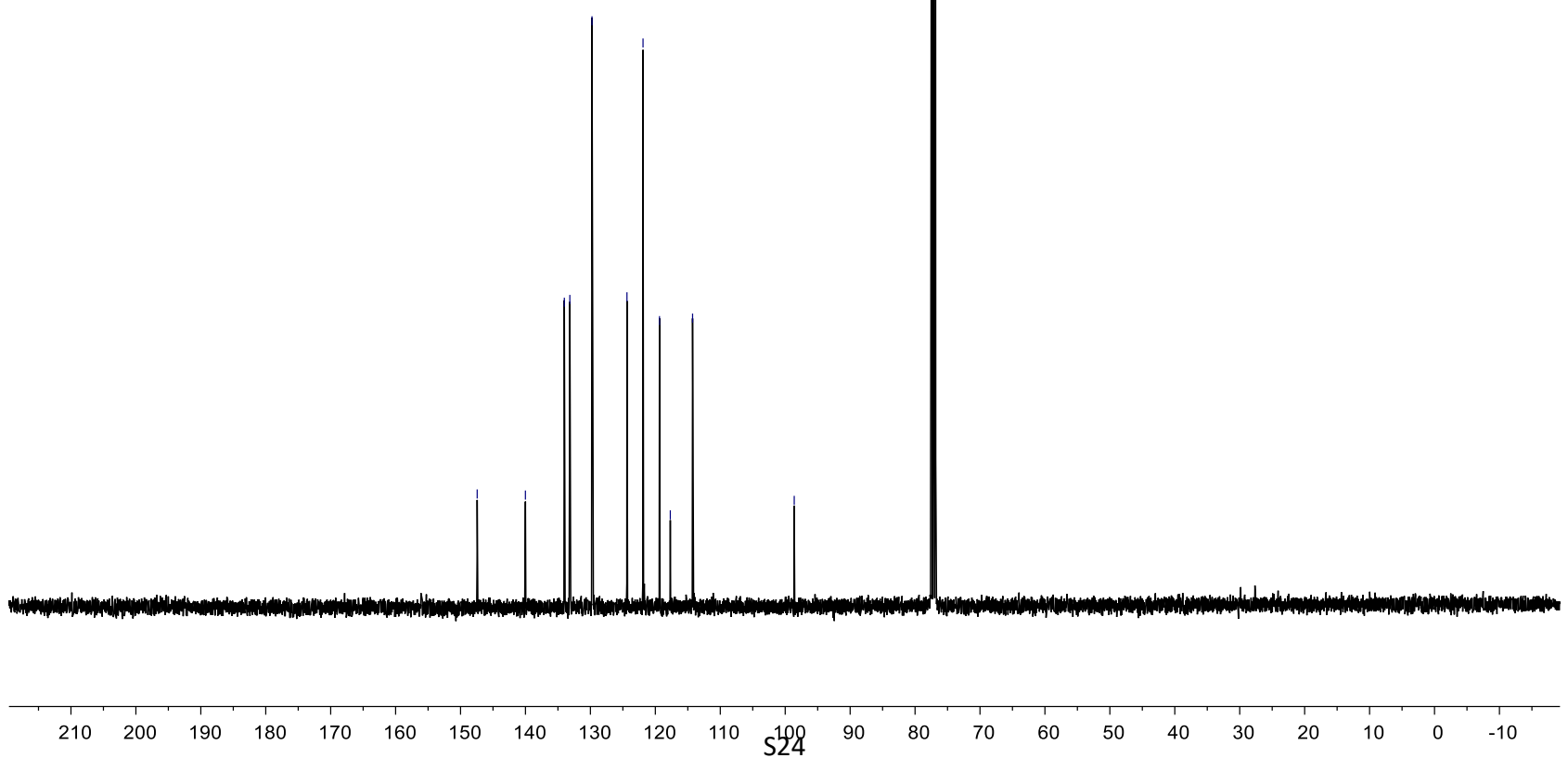




\section{$8-{ }^{1} \mathrm{H}$ NMR}

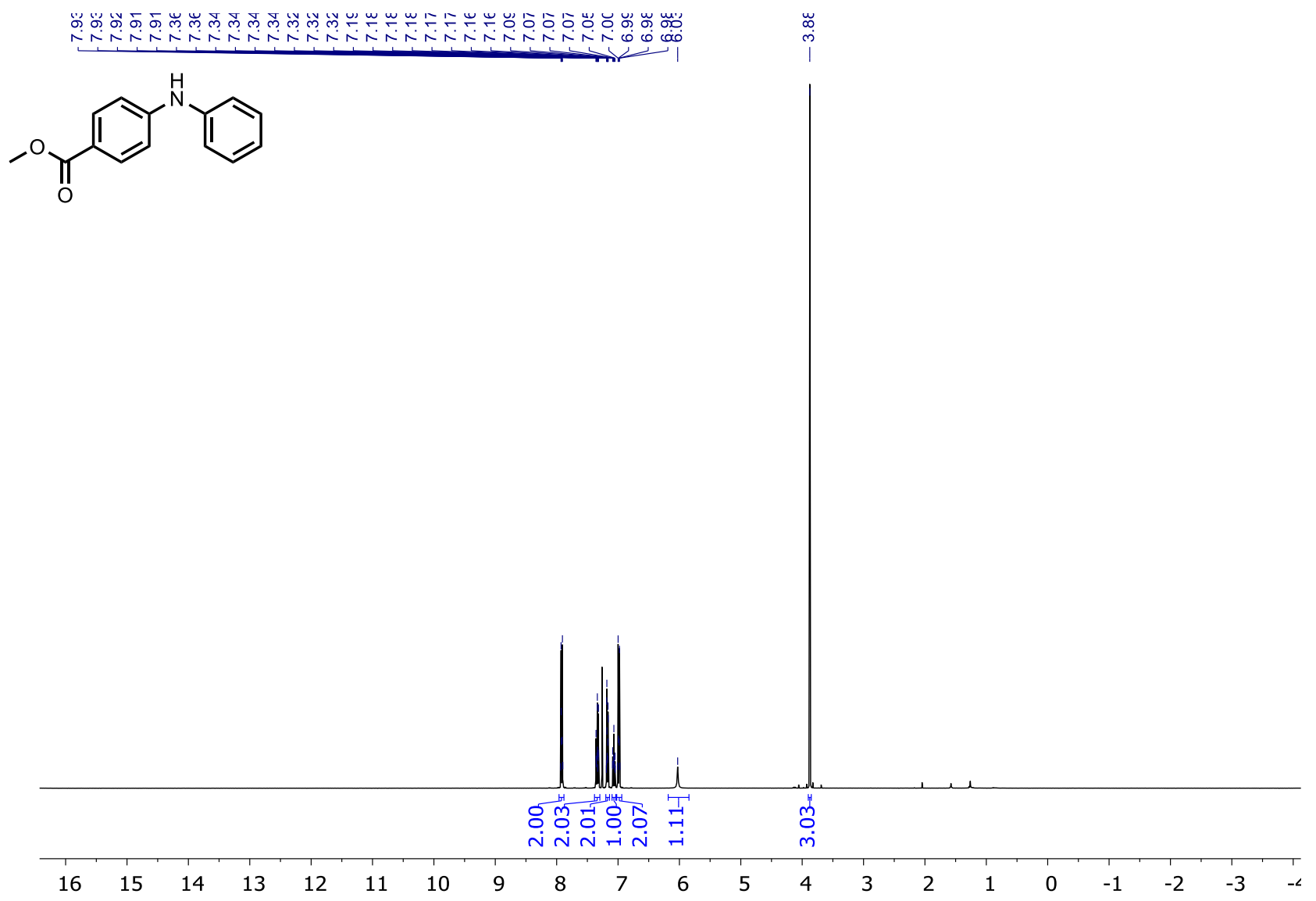

\section{$8-{ }^{13}$ C NMR}

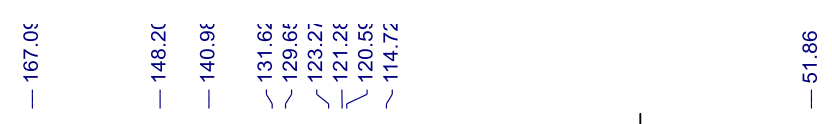




\section{$9-{ }^{1} \mathrm{H}$ NMR}

ఛ

ง<smiles>FC(F)(F)c1cc(Nc2ccccc2)cc(C(F)(F)F)c1</smiles>

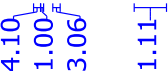

\begin{tabular}{lllllllllllllllllllllll}
\hline 16 & 15 & 14 & 13 & 12 & 11 & 10 & 9 & 8 & 7 & 6 & 5 & 4 & 3 & 2 & 1 & 0 & -1 & -2 & -3 & -4
\end{tabular}

$9-{ }^{13}$ C NMR 


\section{$9-{ }^{19} \mathrm{~F}$ NMR}

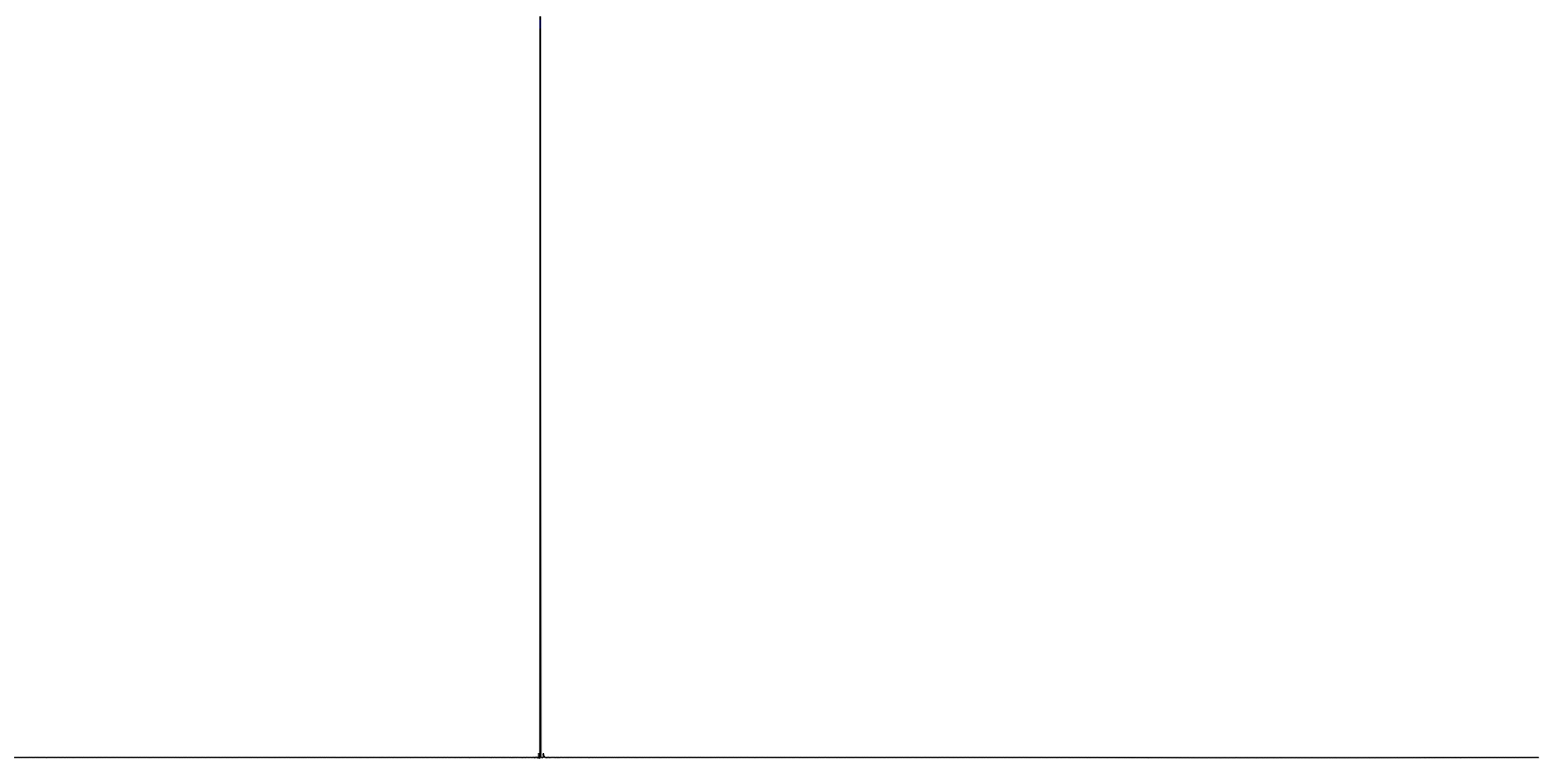

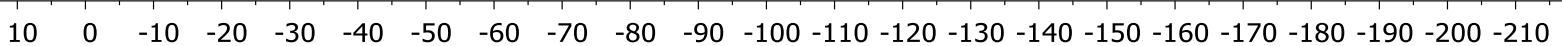


$10-{ }^{1} \mathrm{H} N M R$

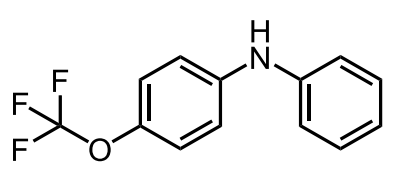

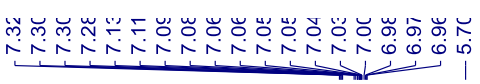

$10-{ }^{13}$ C NMR

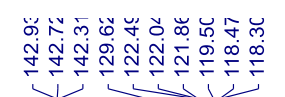

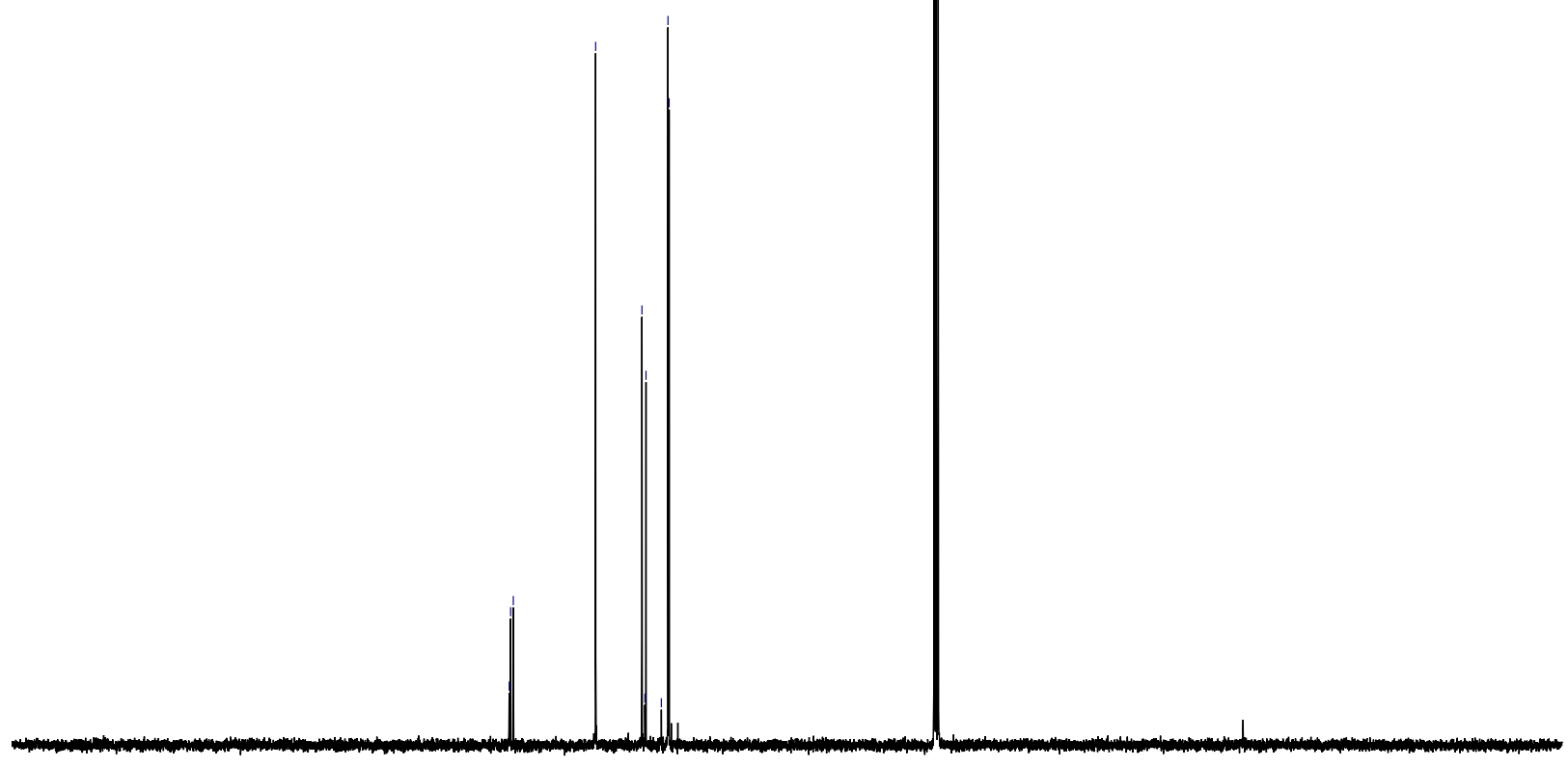

$\begin{array}{lllllllllllllllllllllll}210 & 200 & 190 & 180 & 170 & 160 & 150 & 140 & 130 & 120 & 110 & 100 & 90 & 80 & 70 & 60 & 50 & 40 & 30 & 20 & 10 & 0 & -10\end{array}$

S28 


\section{$10-{ }^{19}$ F NMR}

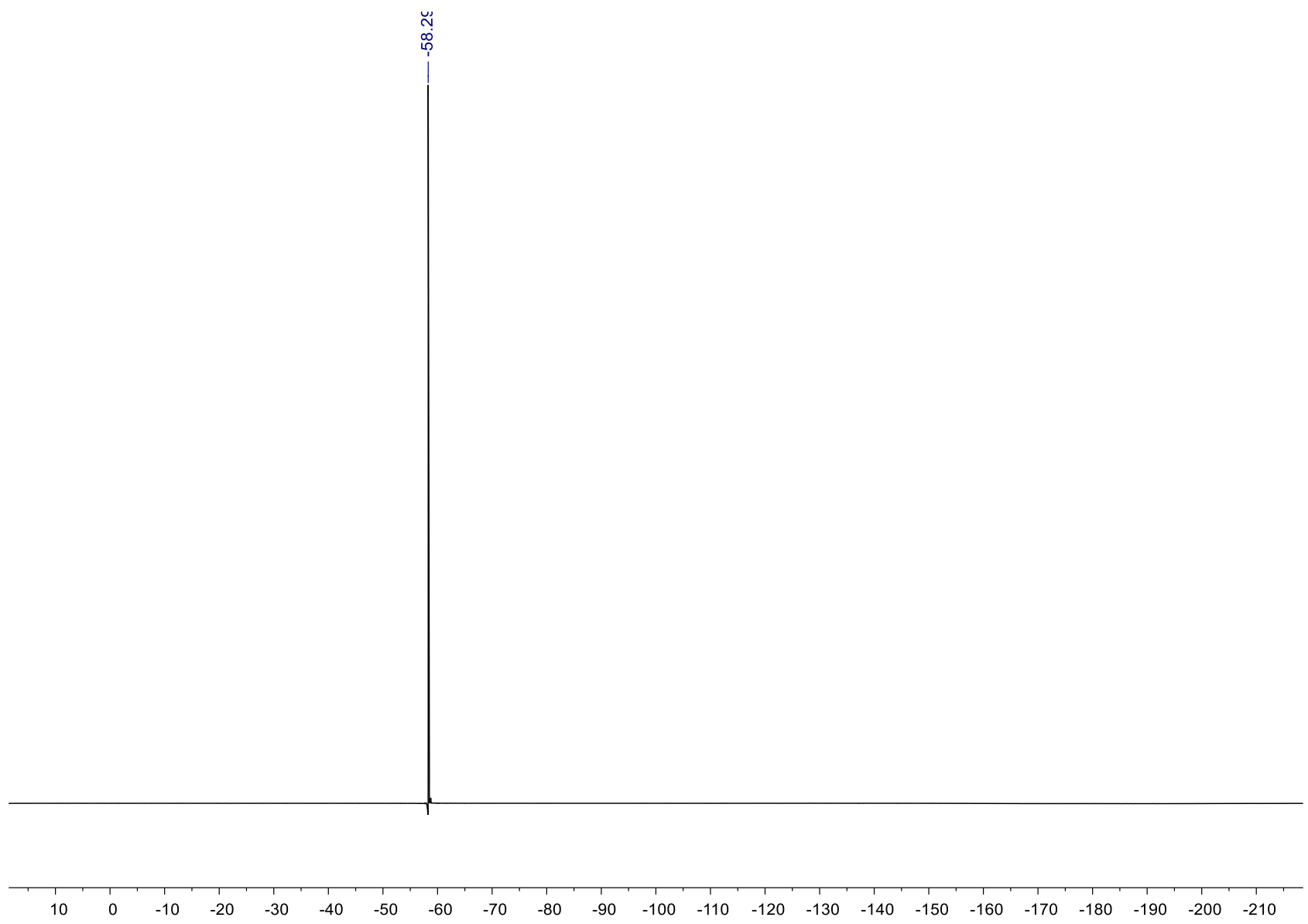


$11-{ }^{1} \mathrm{H}$ NMR

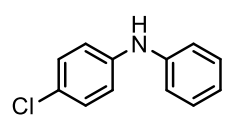

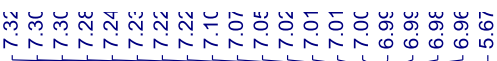

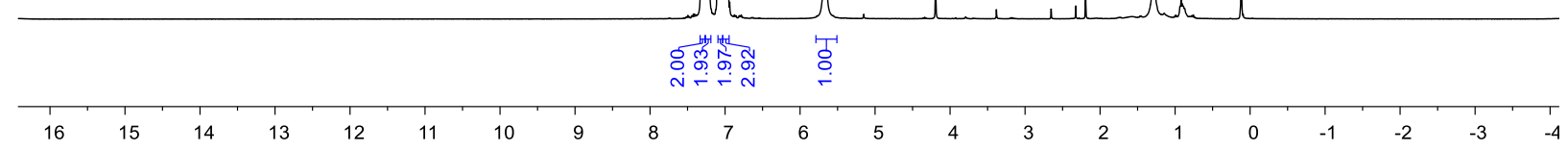

$11-{ }^{13}$ C NMR

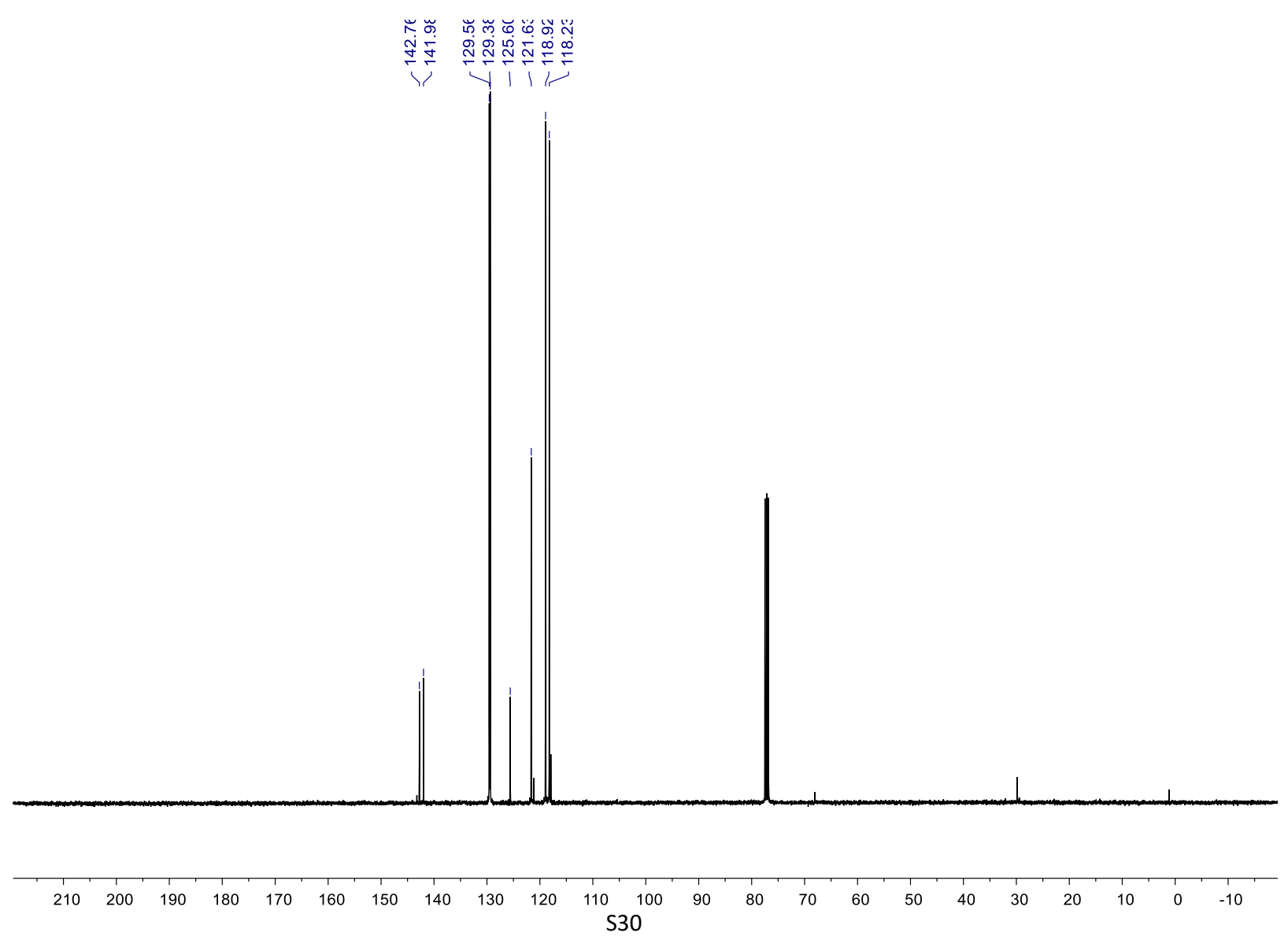


$12-{ }^{1} \mathrm{H}$ NMR<smiles>Brc1ccc(Nc2ccccc2)cc1</smiles>

宽紫紫要

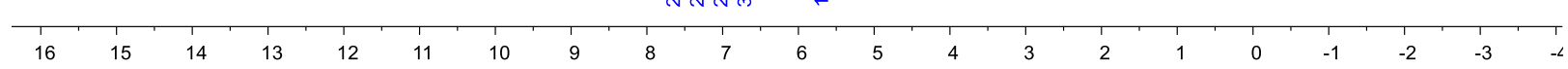

$12-{ }^{13}$ C NMR
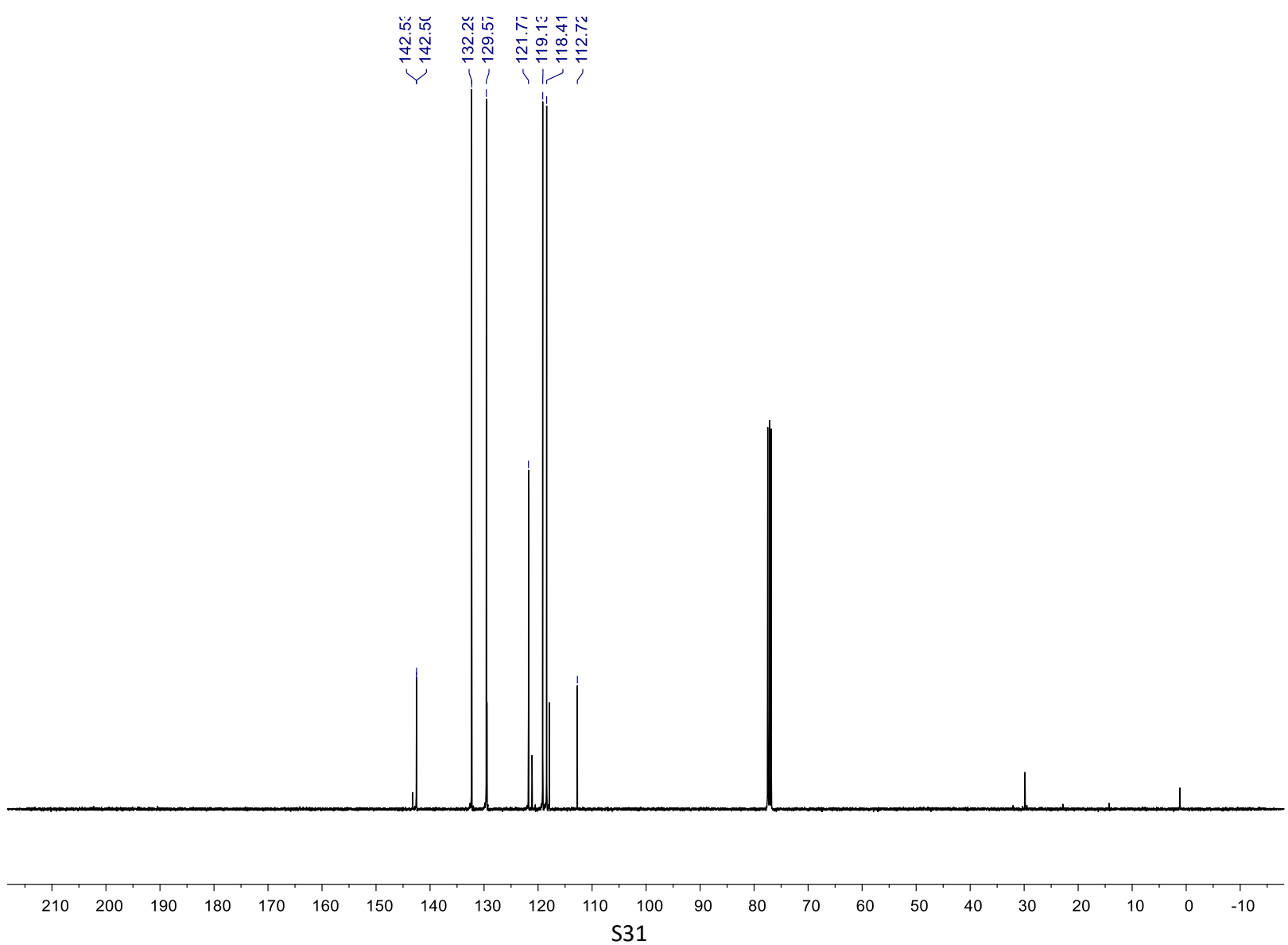
$13-{ }^{1} \mathrm{H}$ NMR

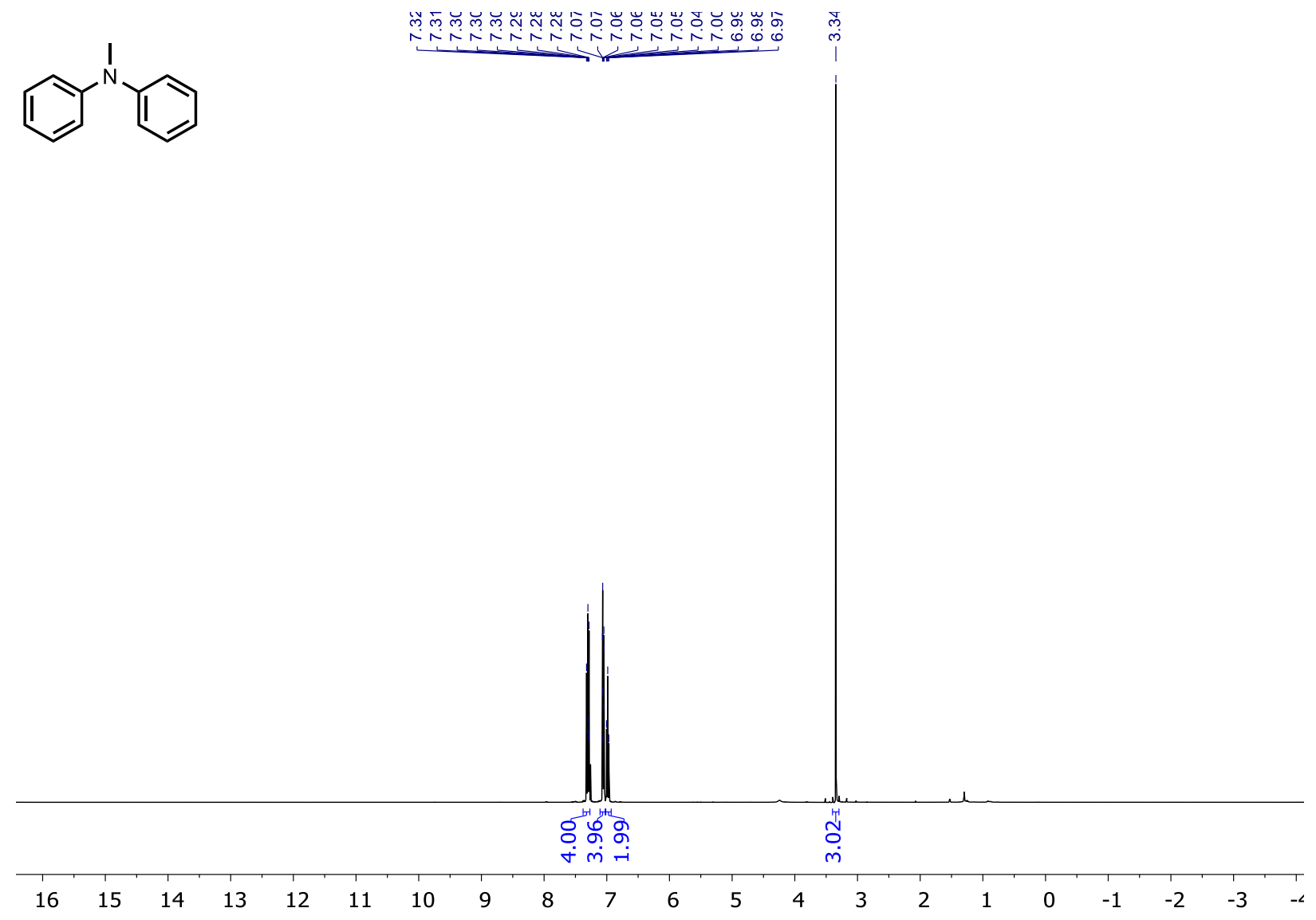

\section{$13-{ }^{13}$ C NMR}

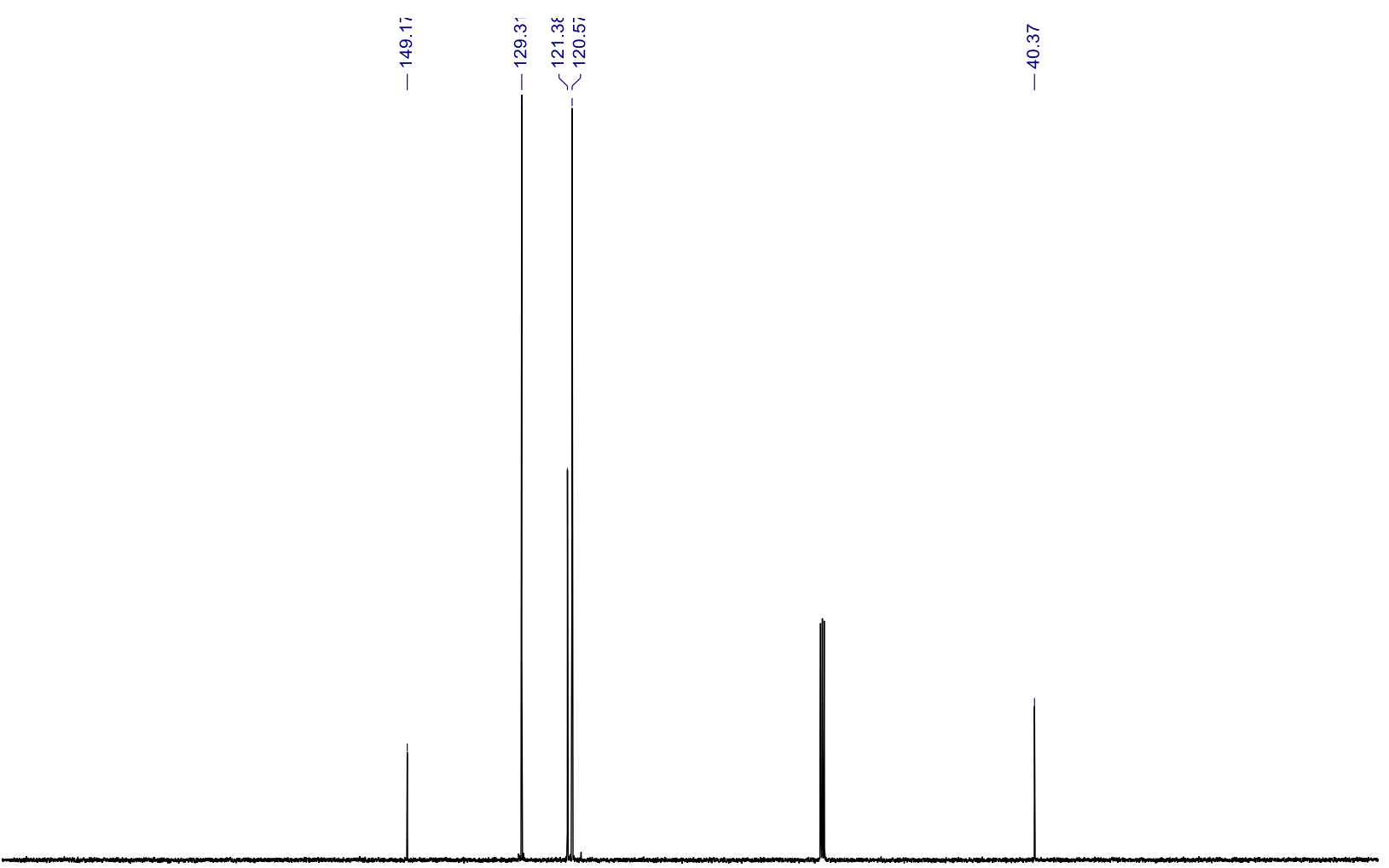


<smiles>CCCCNc1ccccc1</smiles>

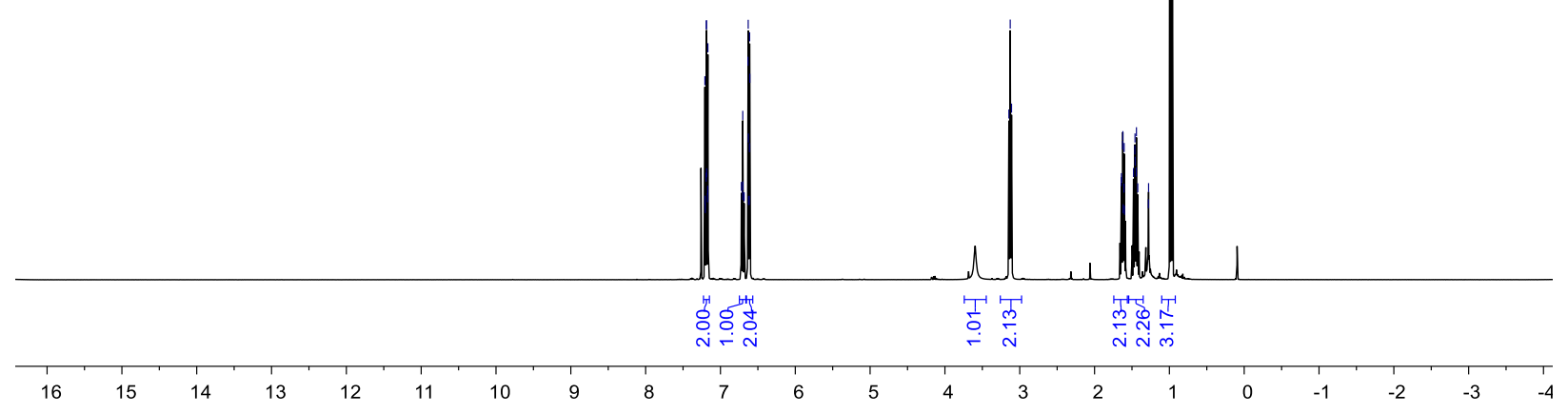

\section{$14-{ }^{13}$ C NMR}

\begin{tabular}{|c|c|c|c|c|c|c|c|}
\hline 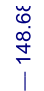 & ले & 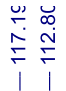 & 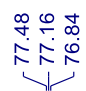 & $\begin{array}{l}\check{\infty} \\
\dot{m} \\
\stackrel{y}{+}\end{array}$ & 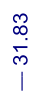 & ֻั. & $\begin{array}{l}\mathscr{0} \\
\dot{+}\end{array}$ \\
\hline
\end{tabular}


<smiles>c1ccc(NC2CCCCC2)cc1</smiles>

o't

i i i

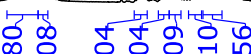
-

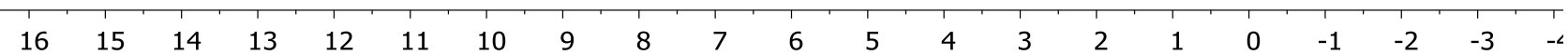

\section{$15-{ }^{13} \mathrm{C}$ NMR}




\section{$16-{ }^{1} \mathrm{H}$ NMR}

లై

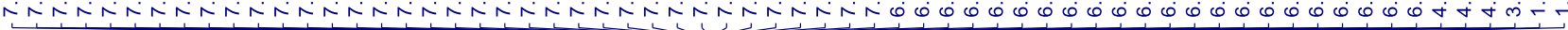<smiles>C[C@H](Nc1ccccc1)c1ccccc1</smiles>

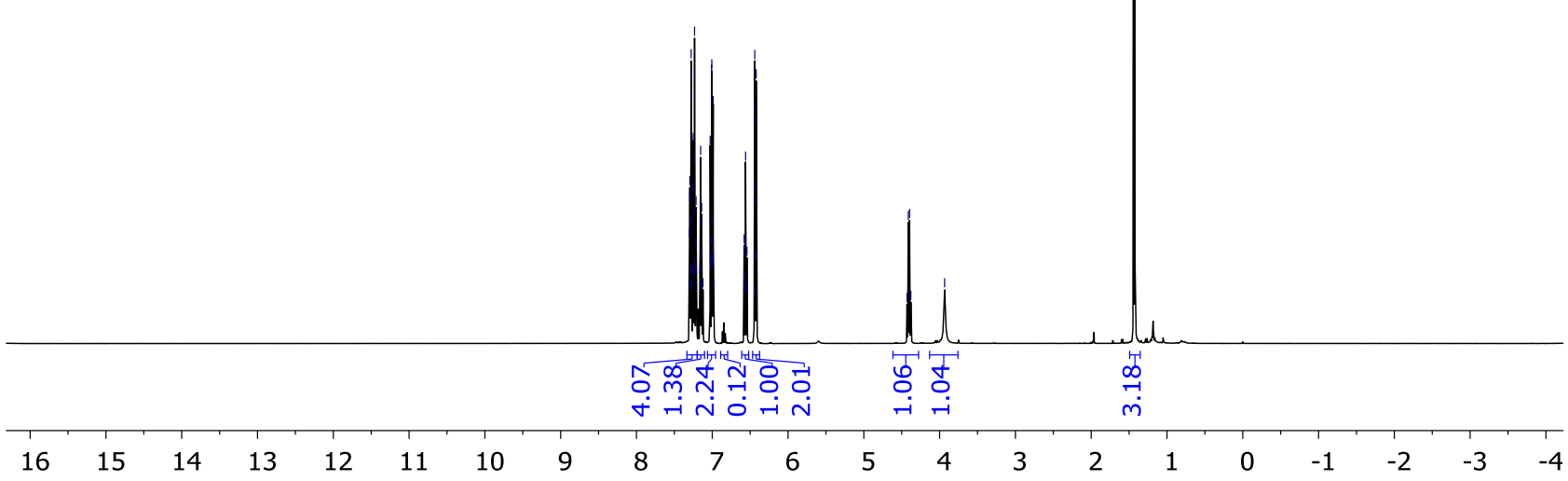

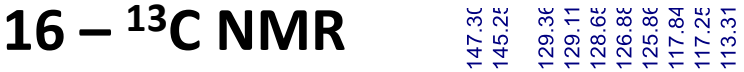 \\ $1 / 2,1$

离


$17-{ }^{1} \mathrm{H}$ NMR

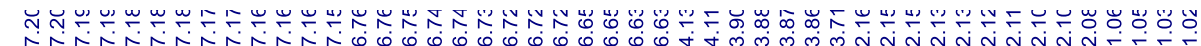<smiles>COC(=O)[C@H](Nc1ccccc1)C(C)C</smiles>
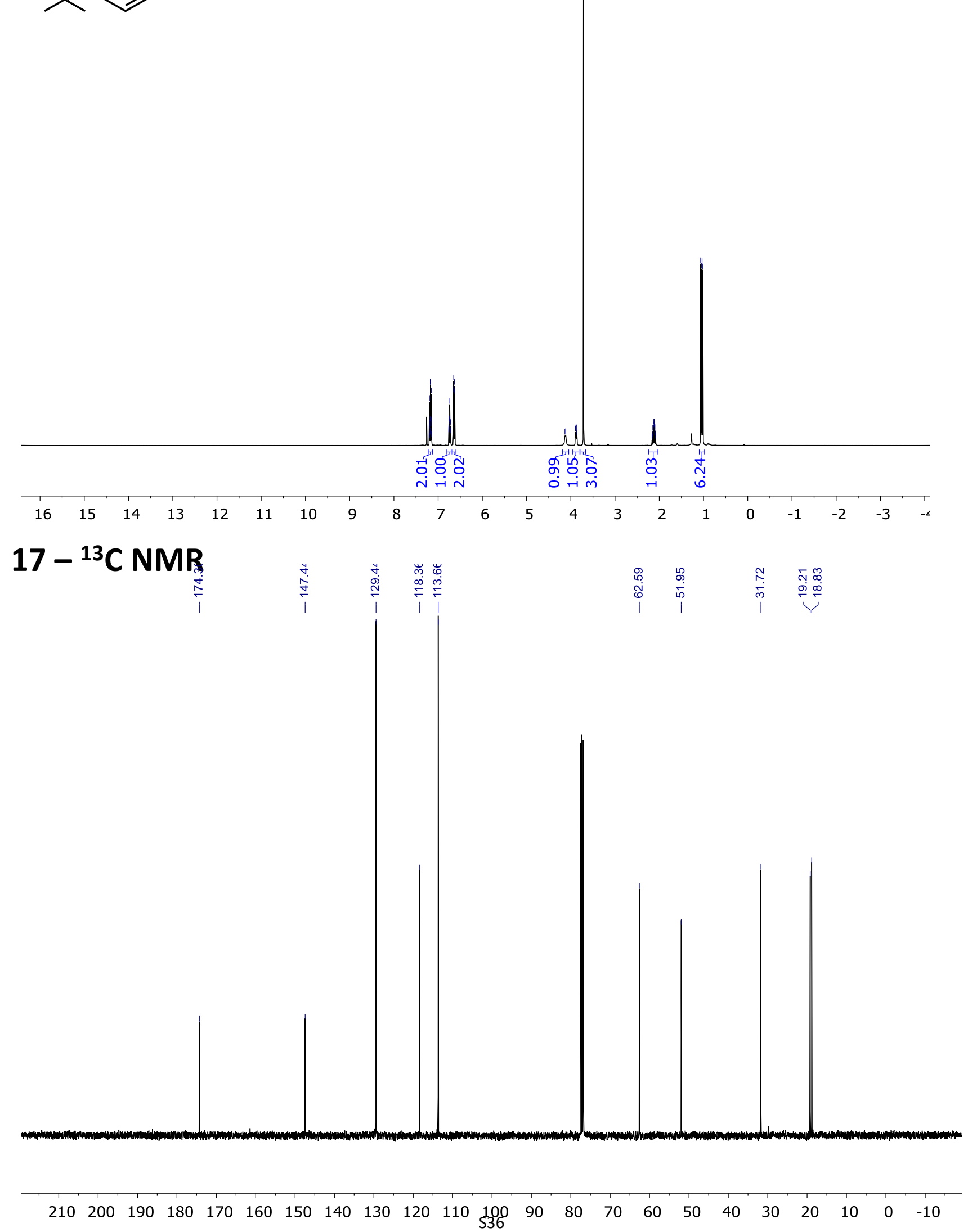
$18-{ }^{1} \mathrm{H} N M R$
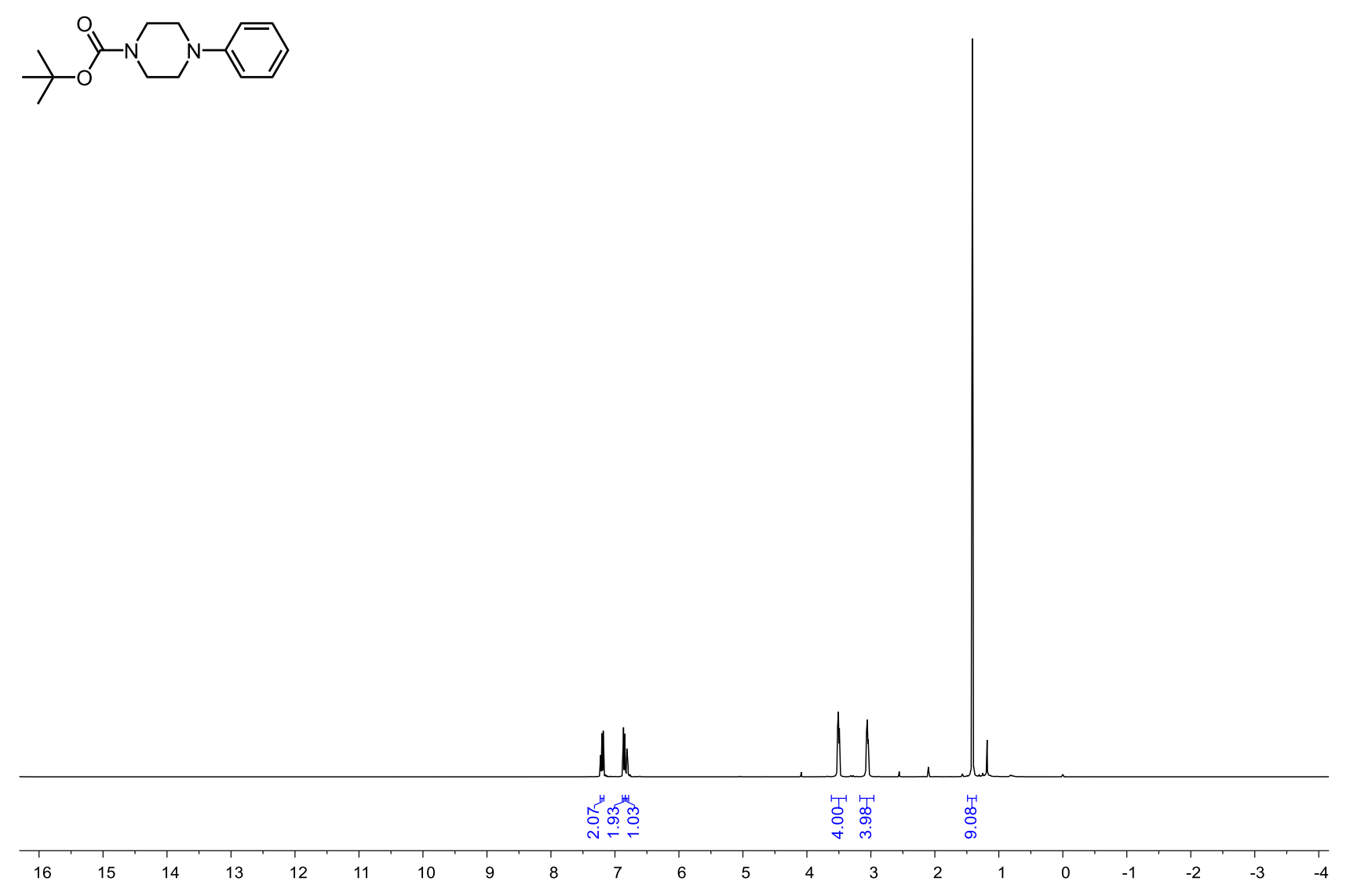

$18-{ }^{13} \mathrm{C}$ NMR

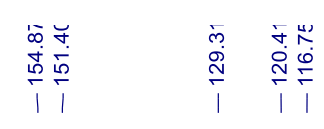
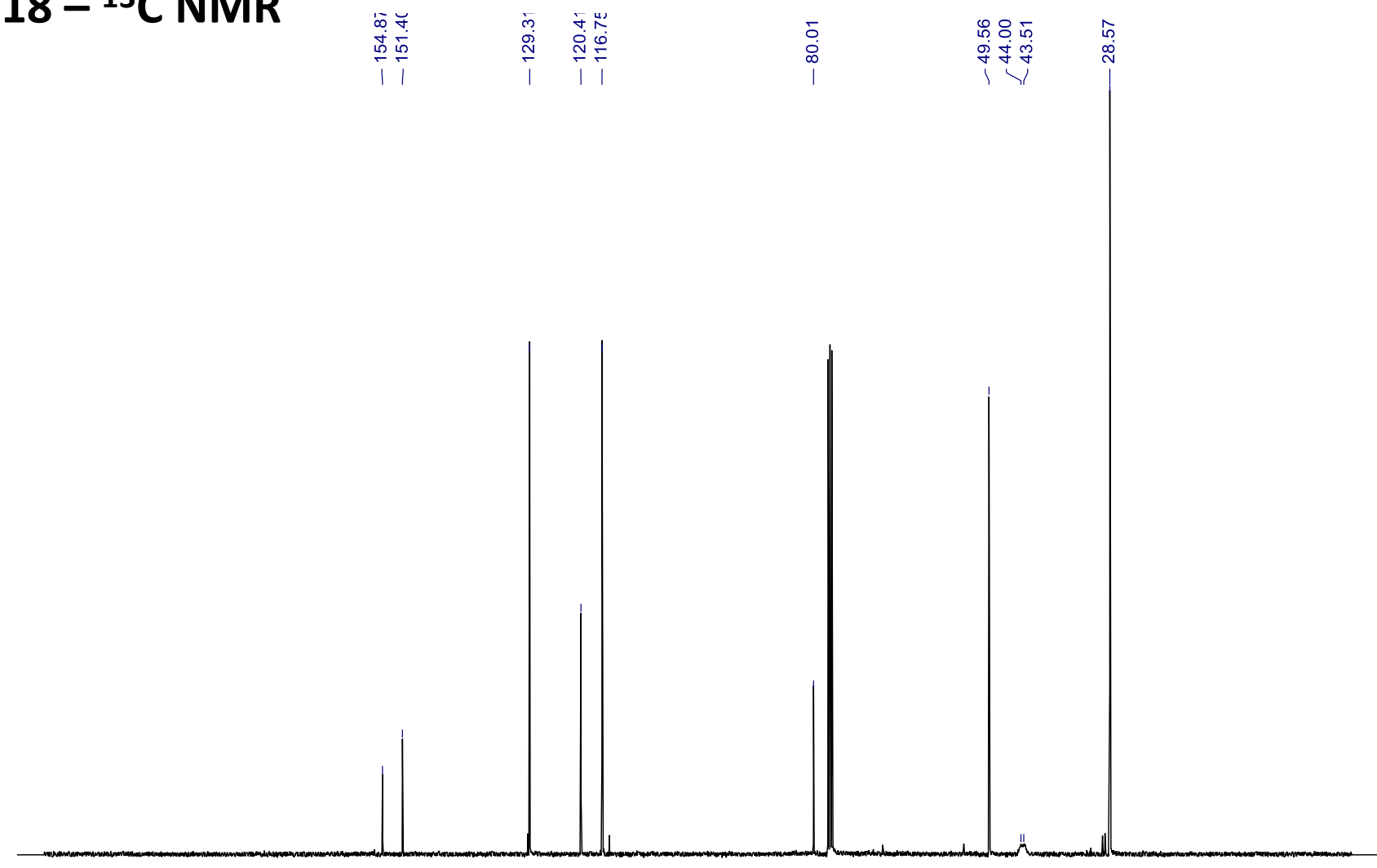

$\begin{array}{llllllllllllllllllllllll}210 & 200 & 190 & 180 & 170 & 160 & 150 & 140 & 130 & 120 & 110 & 100 & 90 & 80 & 70 & 60 & 50 & 40 & 30 & 20 & 10 & 0 & -10\end{array}$ 
<smiles>[O]</smiles>

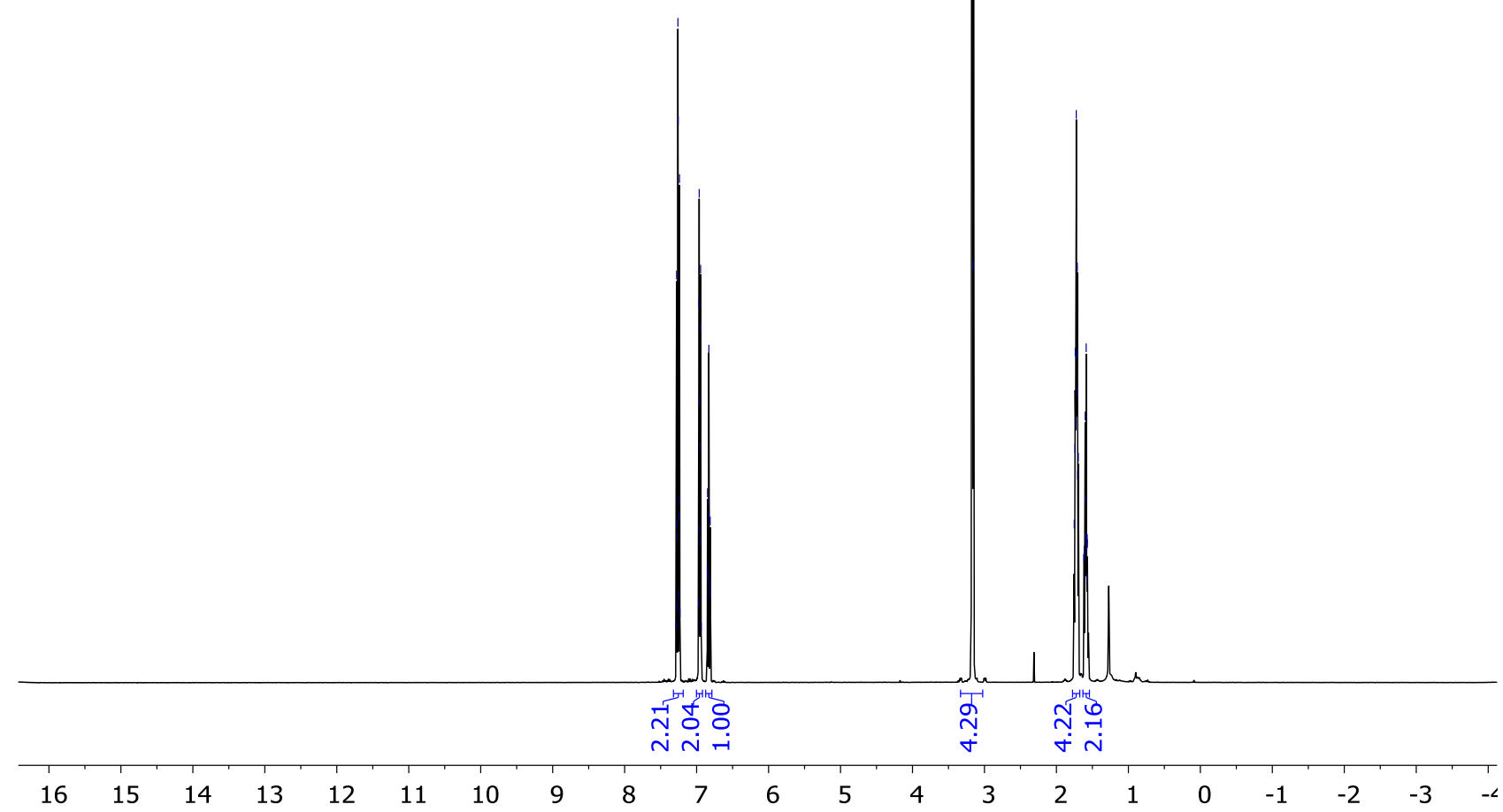

$19-{ }^{13}$ C NMR

\begin{tabular}{|c|}
\hline 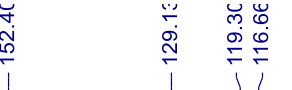 \\
\hline
\end{tabular}




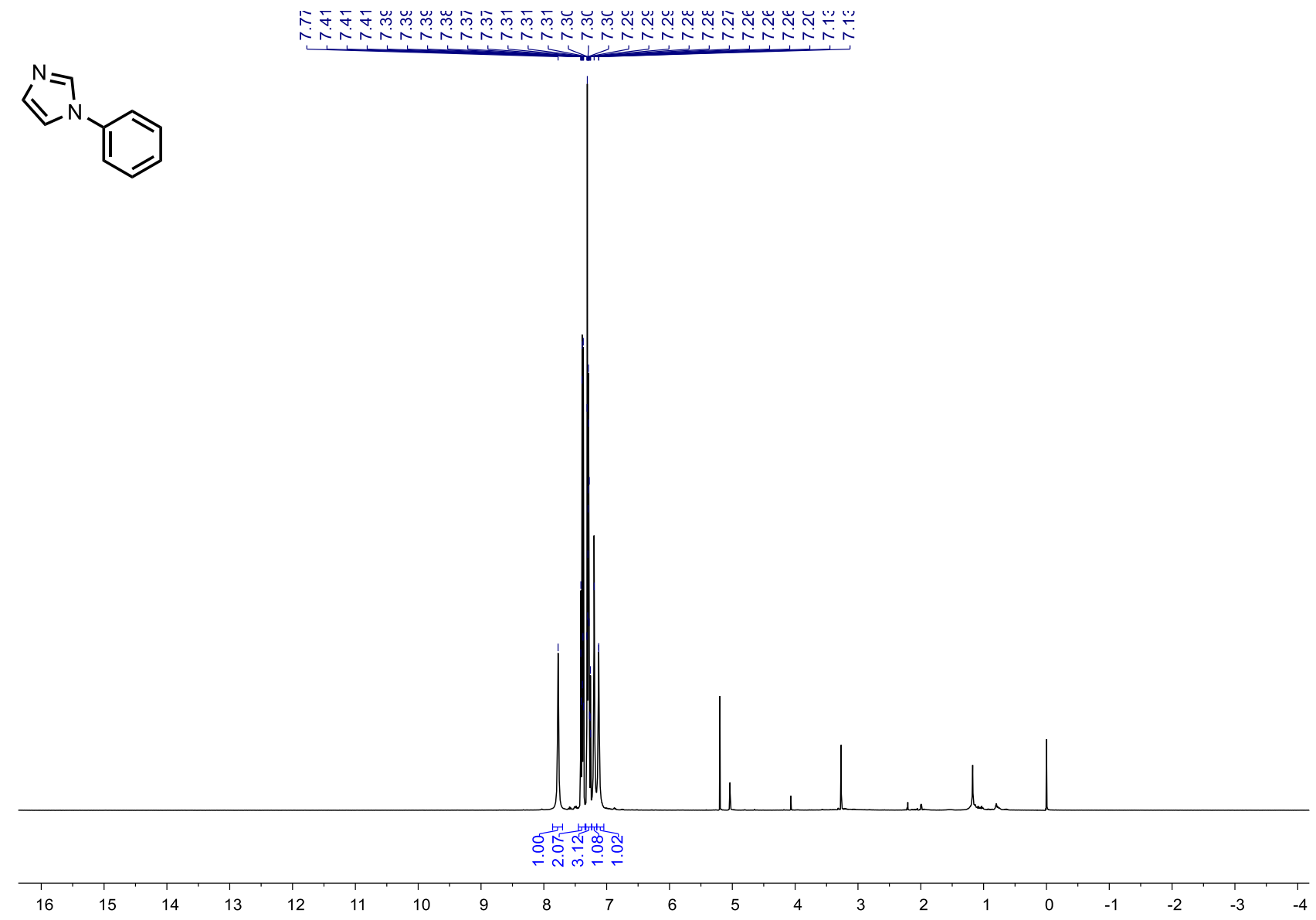

\section{$20-{ }^{13}$ C NMR}

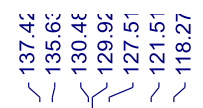


<smiles>c1ccc(Nc2ccccn2)cc1</smiles>

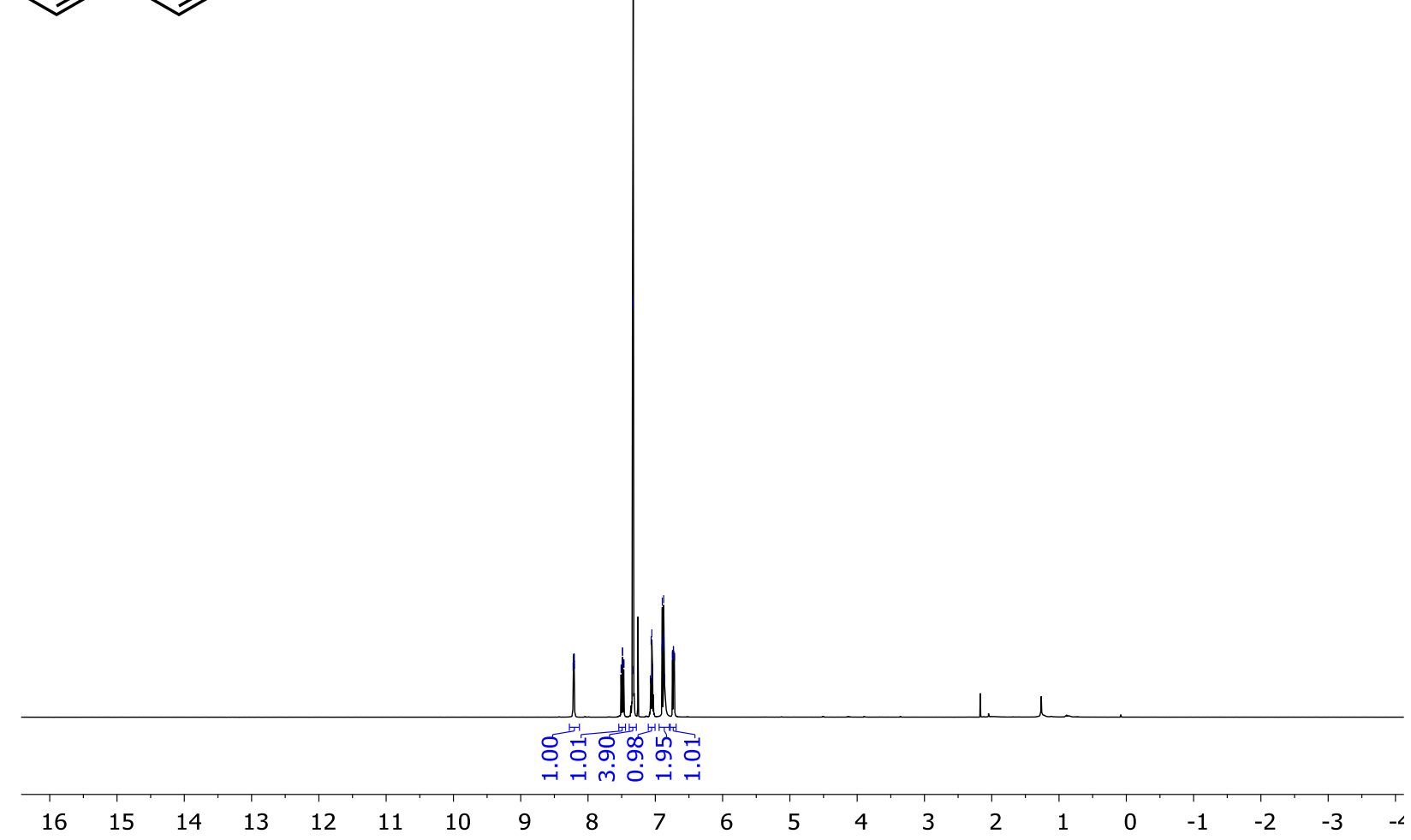

\section{$21-{ }^{13}$ C NMR}

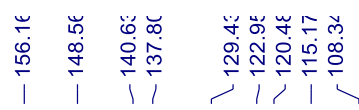


$22-{ }^{1} \mathrm{H} N M R$

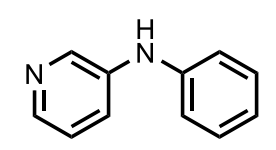

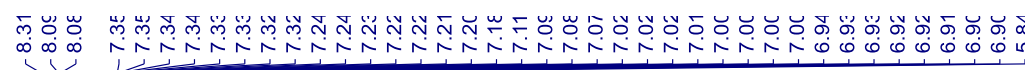

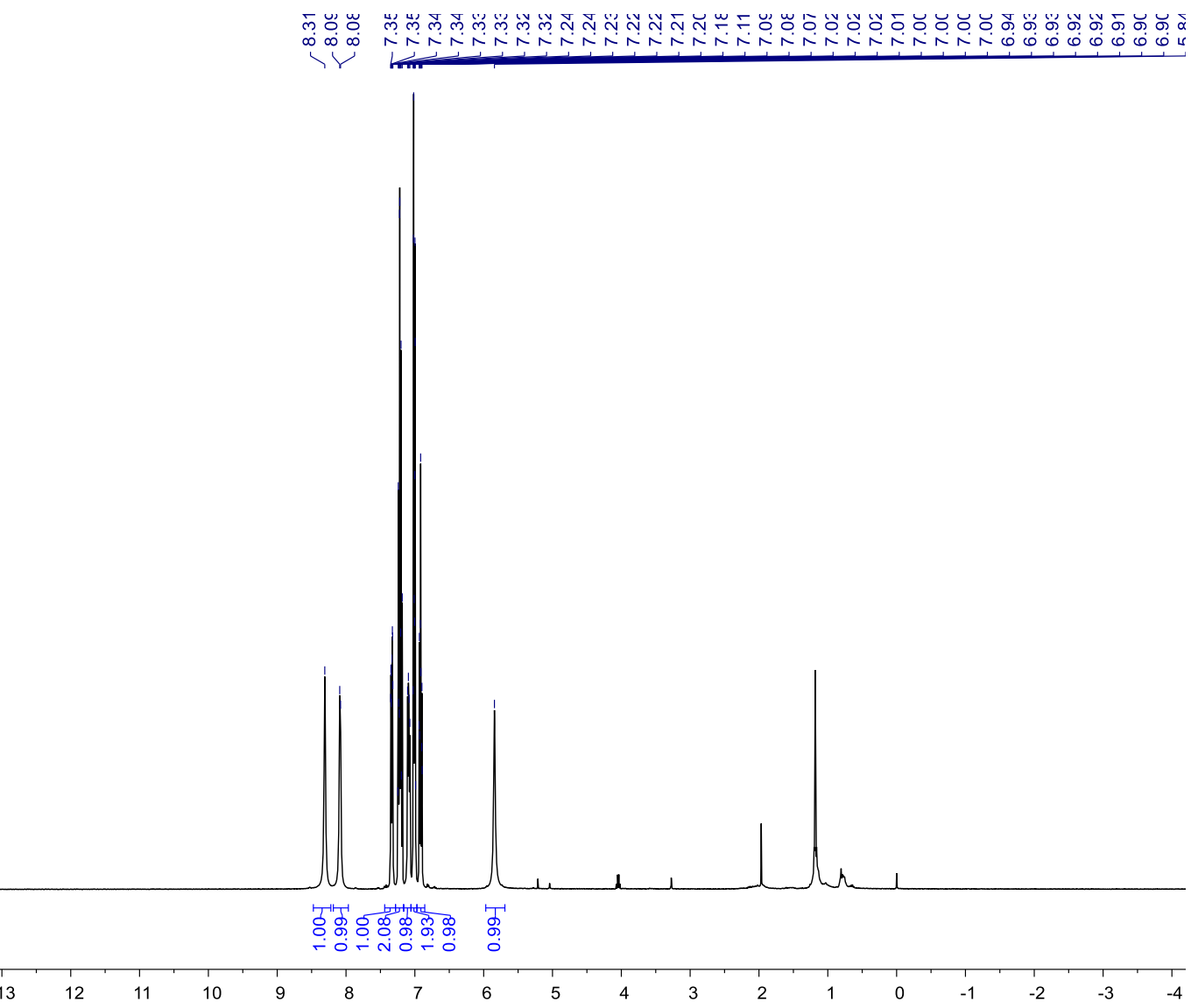

$22-{ }^{13}$ C NMR

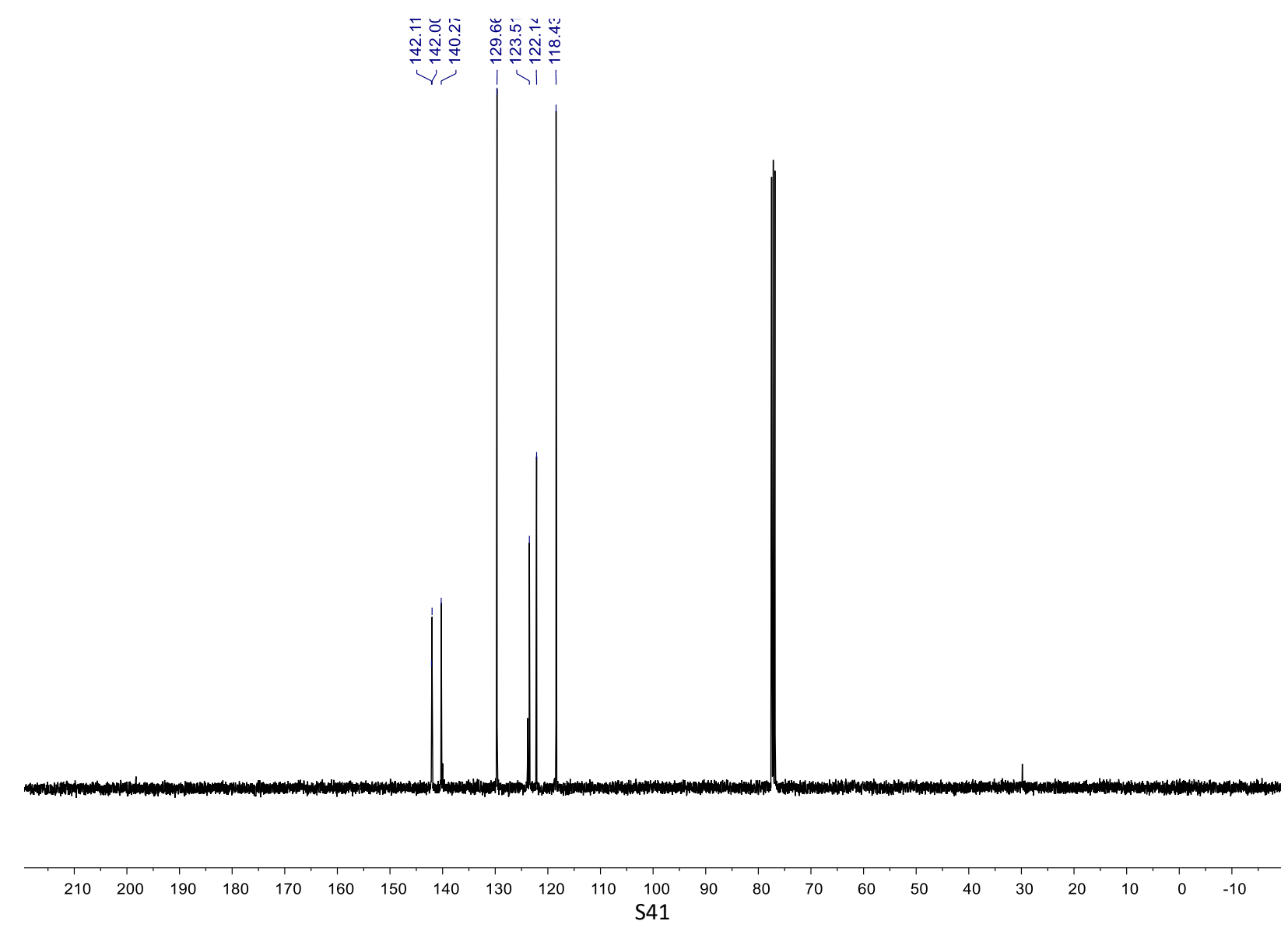


<smiles>c1ccc(Oc2ccccc2)cc1</smiles>

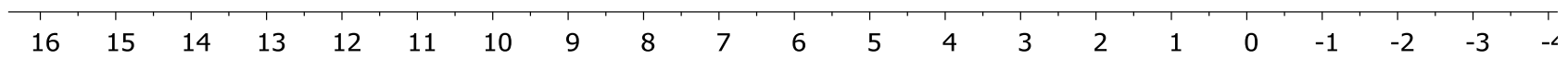

$23-{ }^{13}$ C NMR

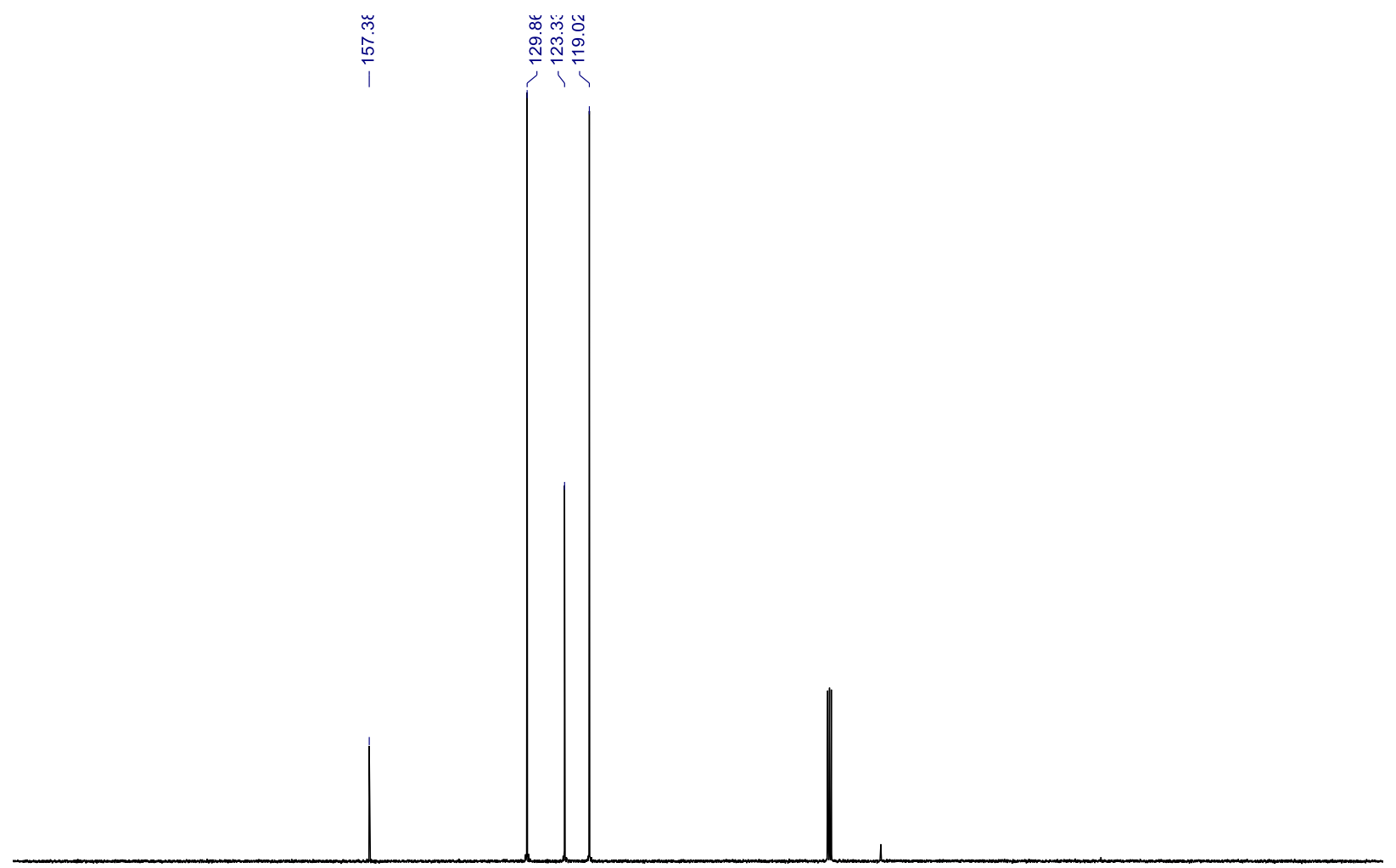




\section{$24-{ }^{1} \mathrm{H}$ NMR}

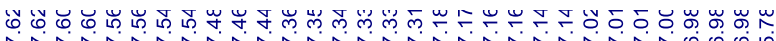

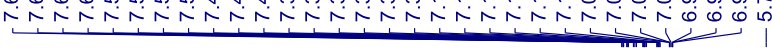

(N)

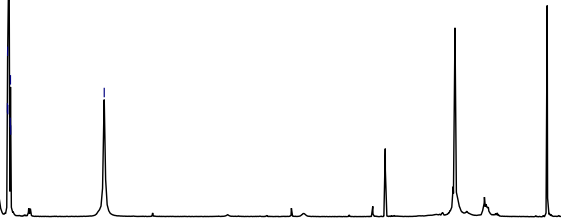

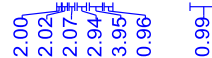

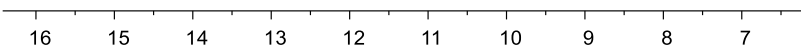

$24-{ }^{13}$ C NMR

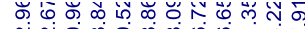

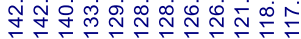

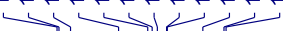


$25-{ }^{1}$ H NMR<smiles>CC(C)(C)c1ccc(Nc2ccccc2)cc1</smiles>

|

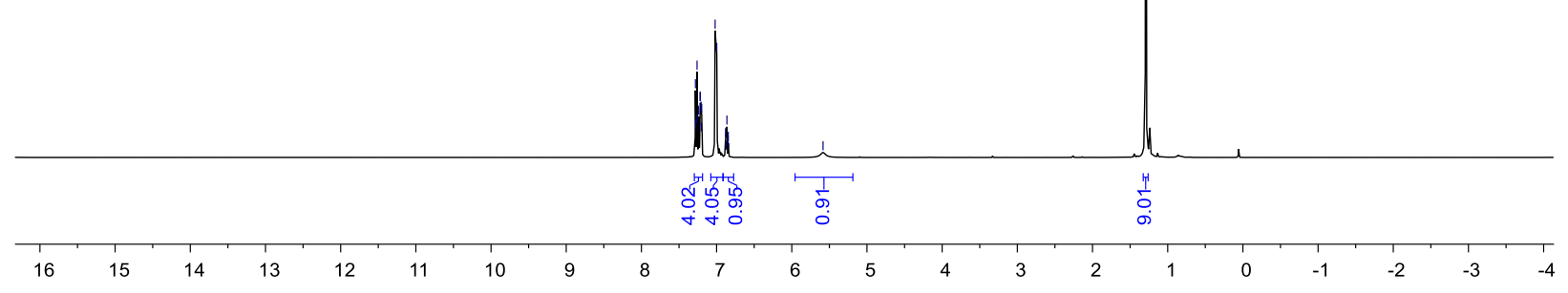

$25-{ }^{13}$ C NMR

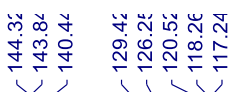
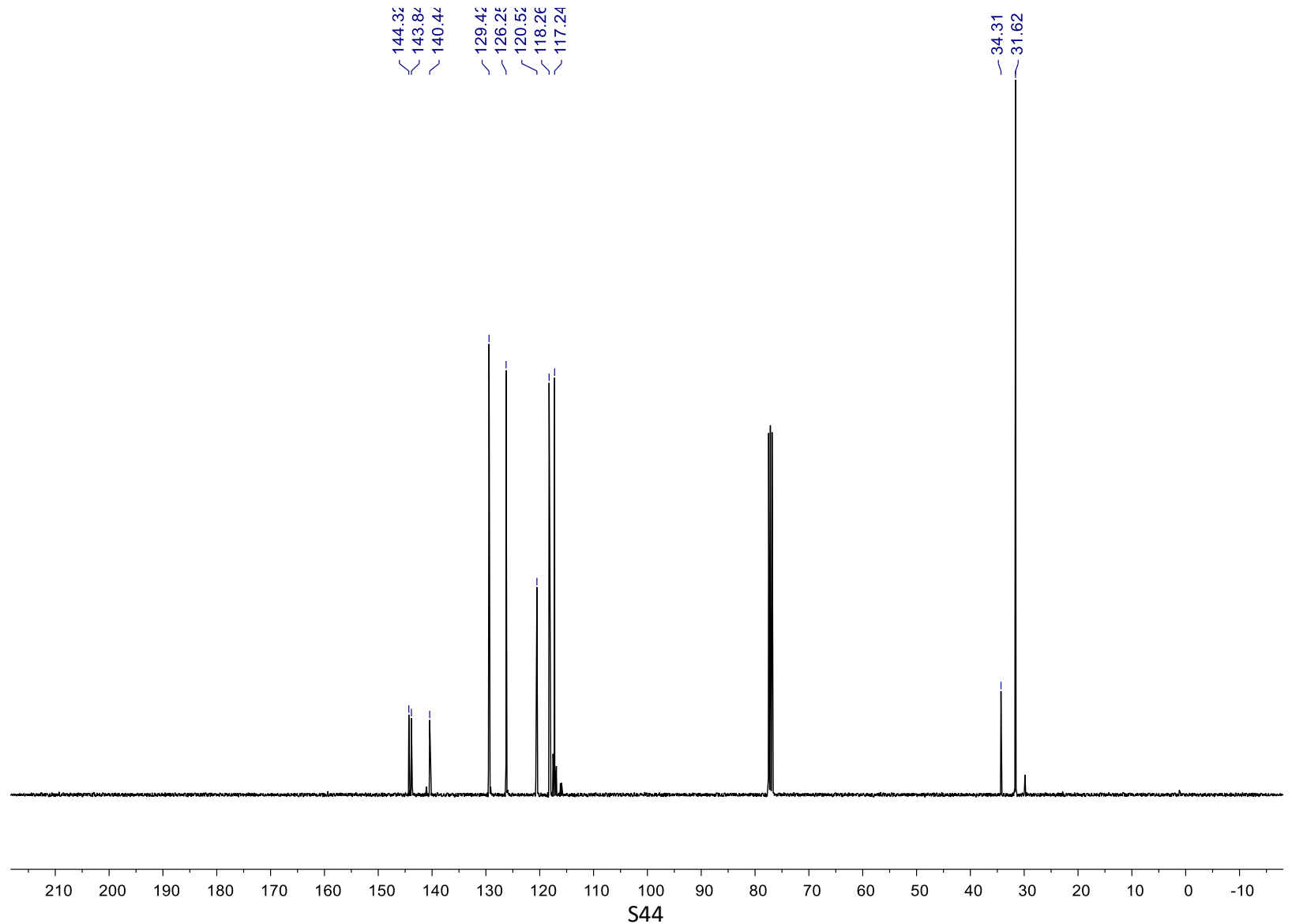
$26-{ }^{1} \mathrm{H} N M R$

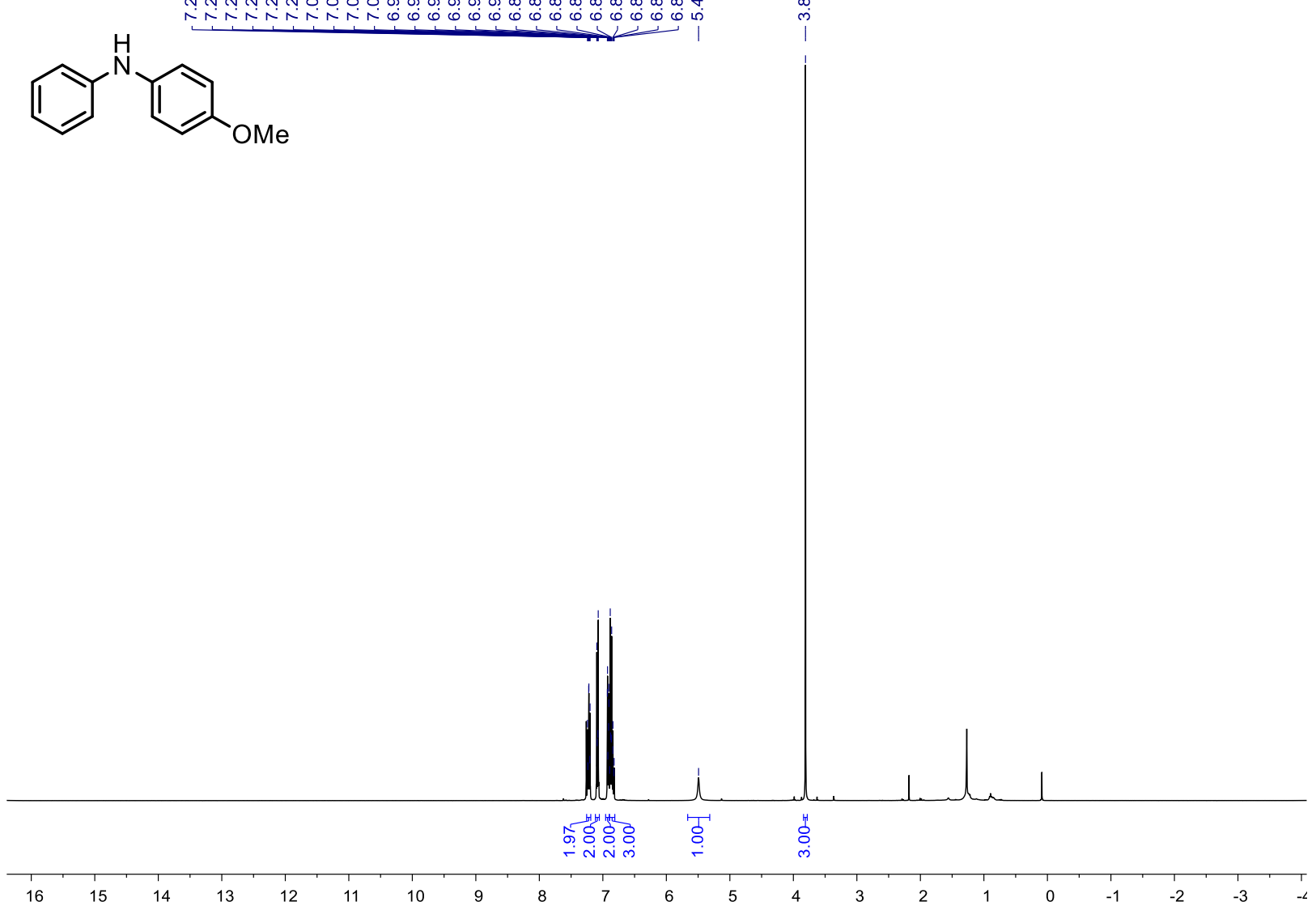

$26-{ }^{13}$ C NMR

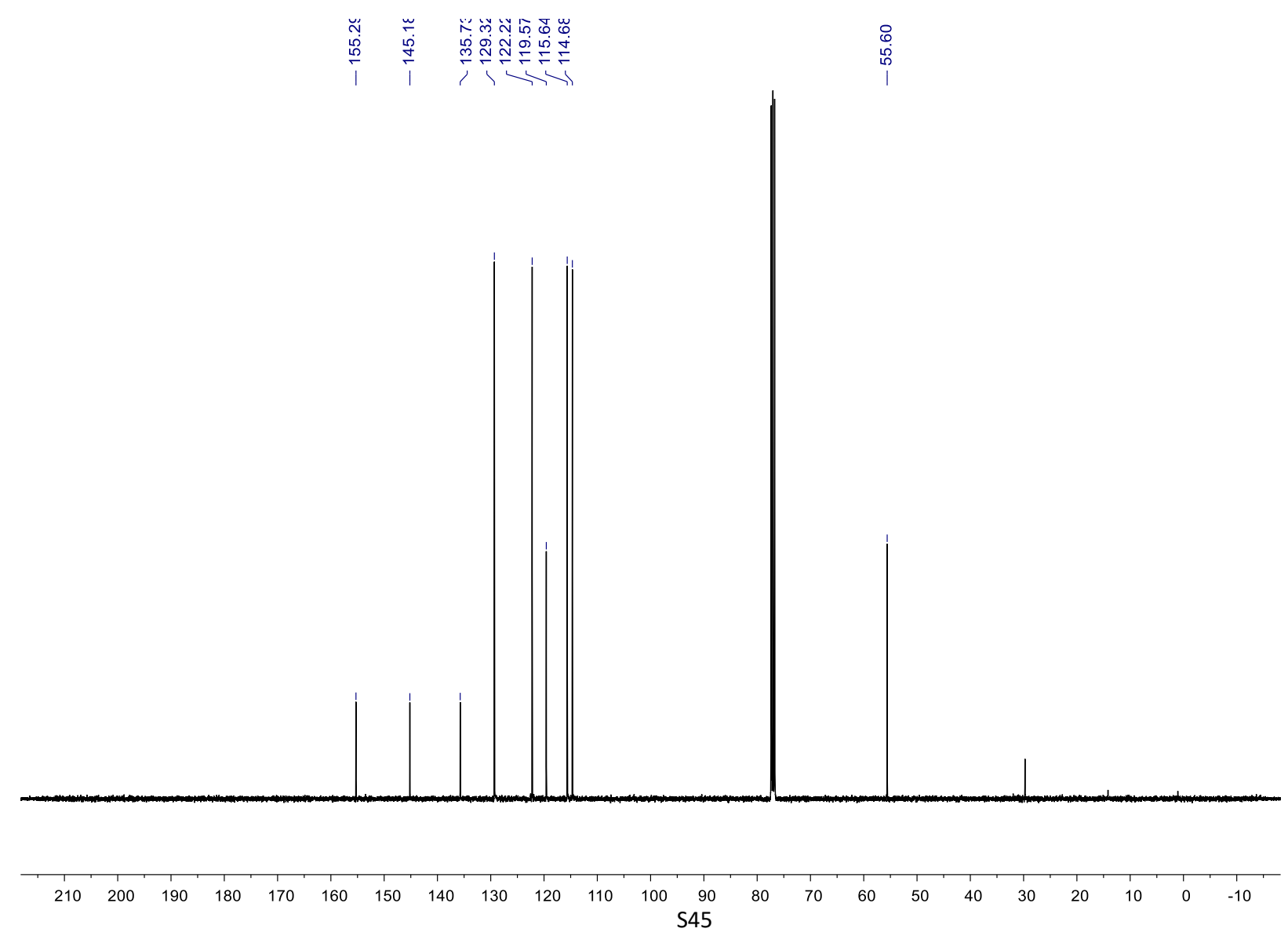


$27-{ }^{1} \mathrm{H}$ NMR<smiles>Cc1ccccc1Nc1ccccc1</smiles>

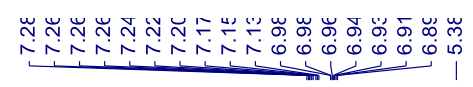

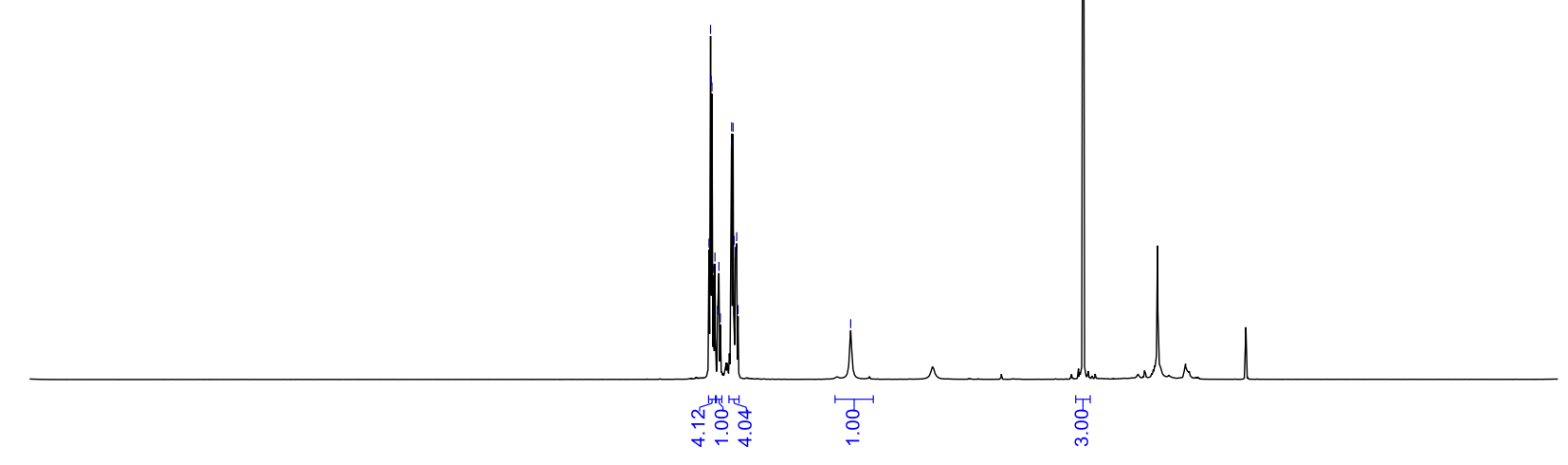

$27-{ }^{13} \mathrm{C} N \mathrm{NMR}$

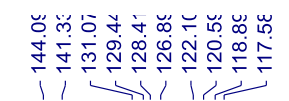

$\stackrel{\substack{0 \\ \infty}}{\stackrel{\infty}{\infty}}$

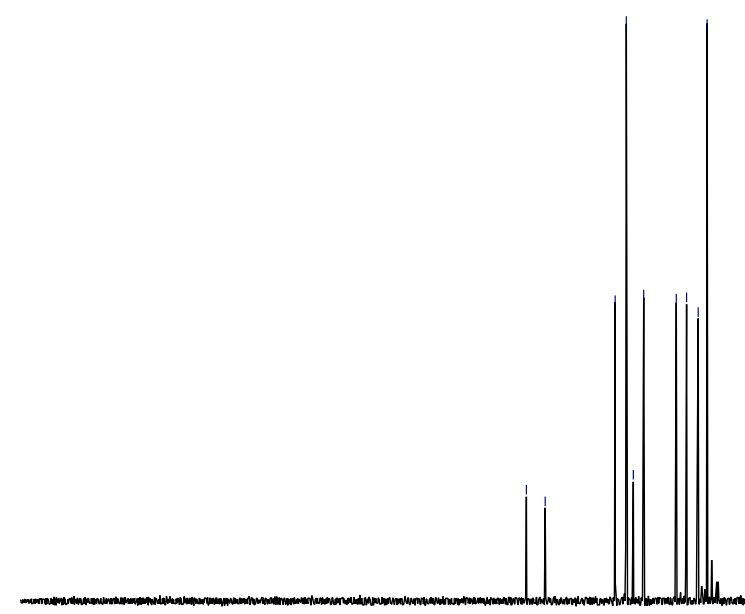

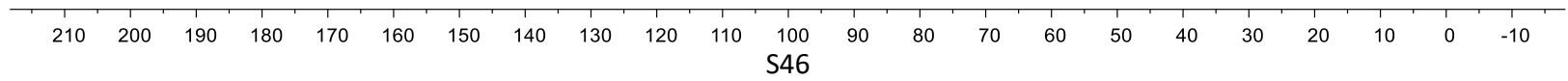


<smiles>c1ccc(Nc2ccccc2OPc2ccccc2)cc1</smiles>

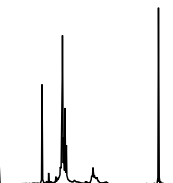

ठูป

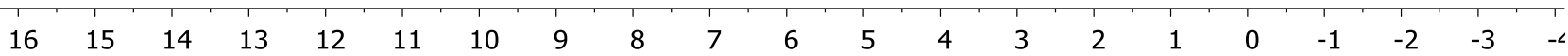


$29-{ }^{1} \mathrm{H}$ NMR<smiles>FC(F)(F)c1ccc(Nc2ccccc2)cc1</smiles>

\section{传}

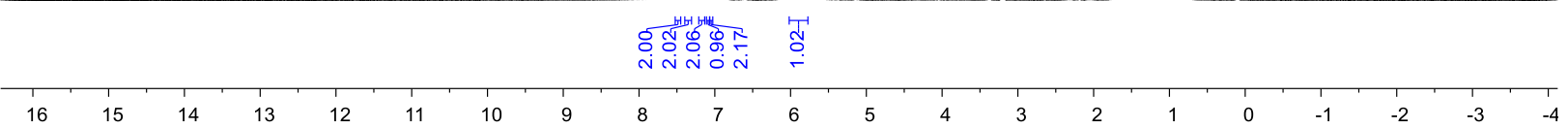

\section{$29-{ }^{13}$ C NMR}

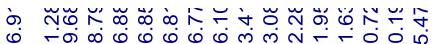

政

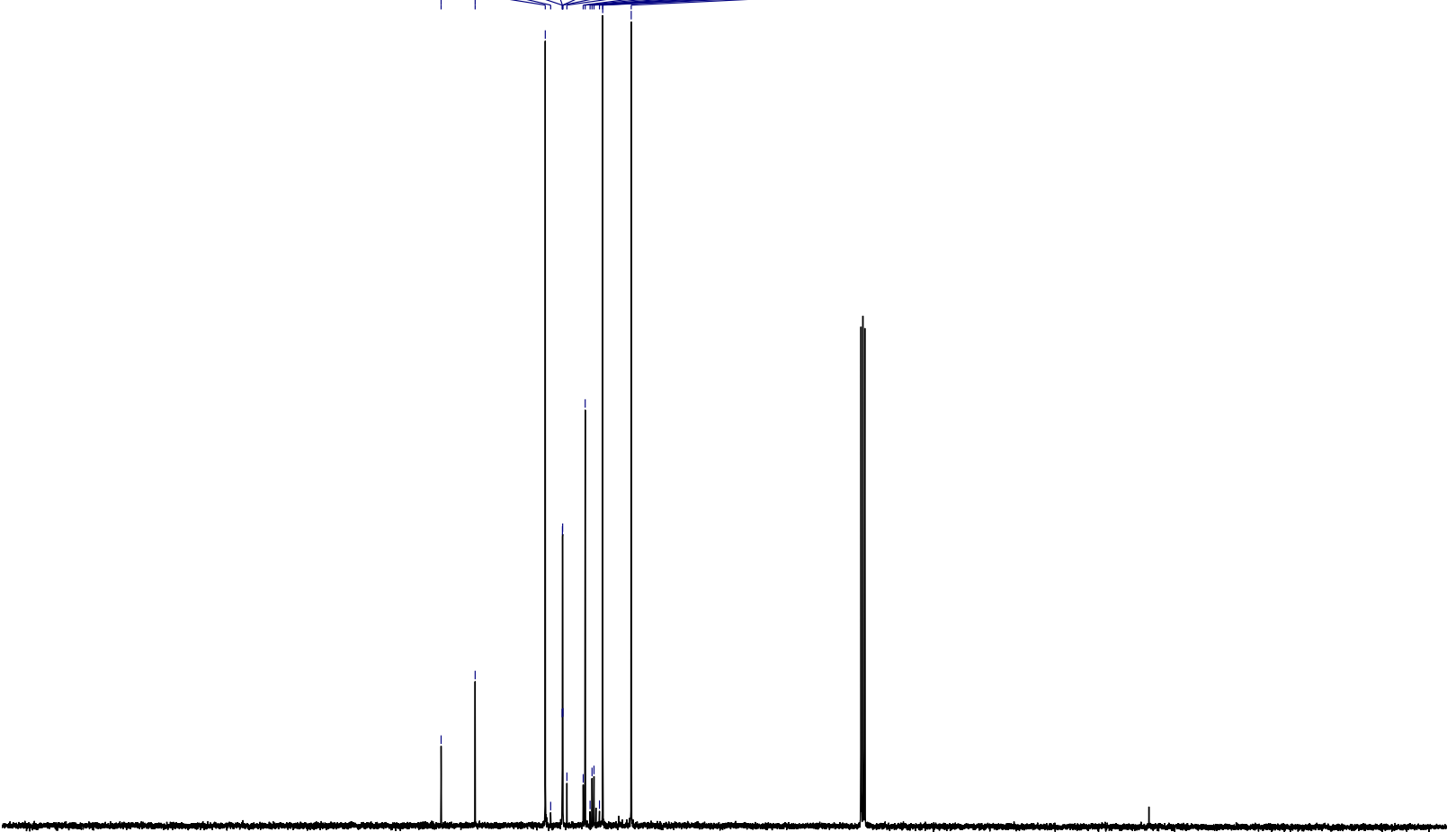




\section{$29-{ }^{19}$ F NMR}

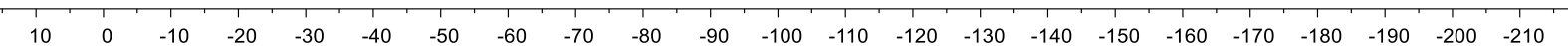


$30-{ }^{1} \mathrm{H}$ NMR
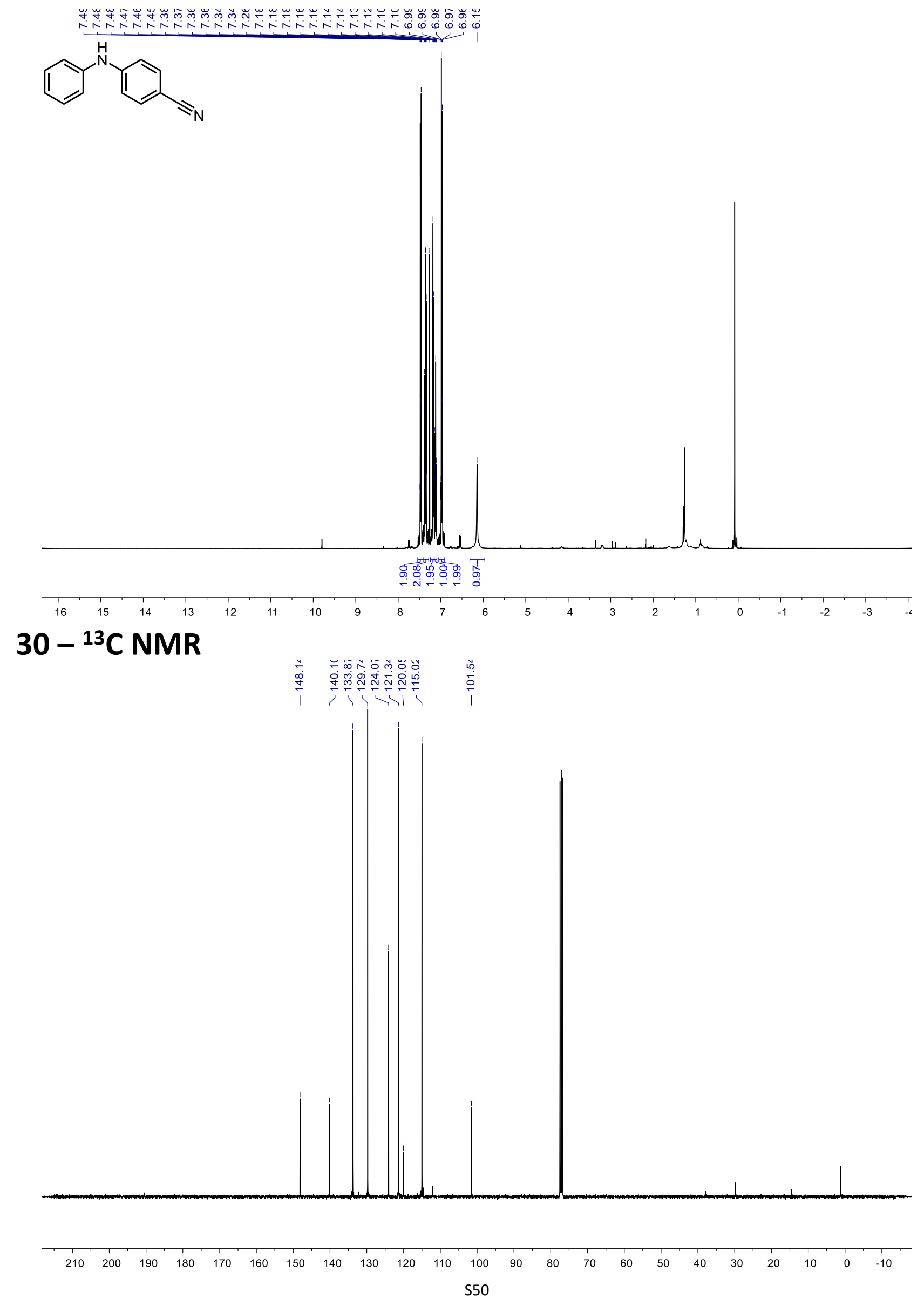
$31-{ }^{1} \mathrm{H}$ NMR

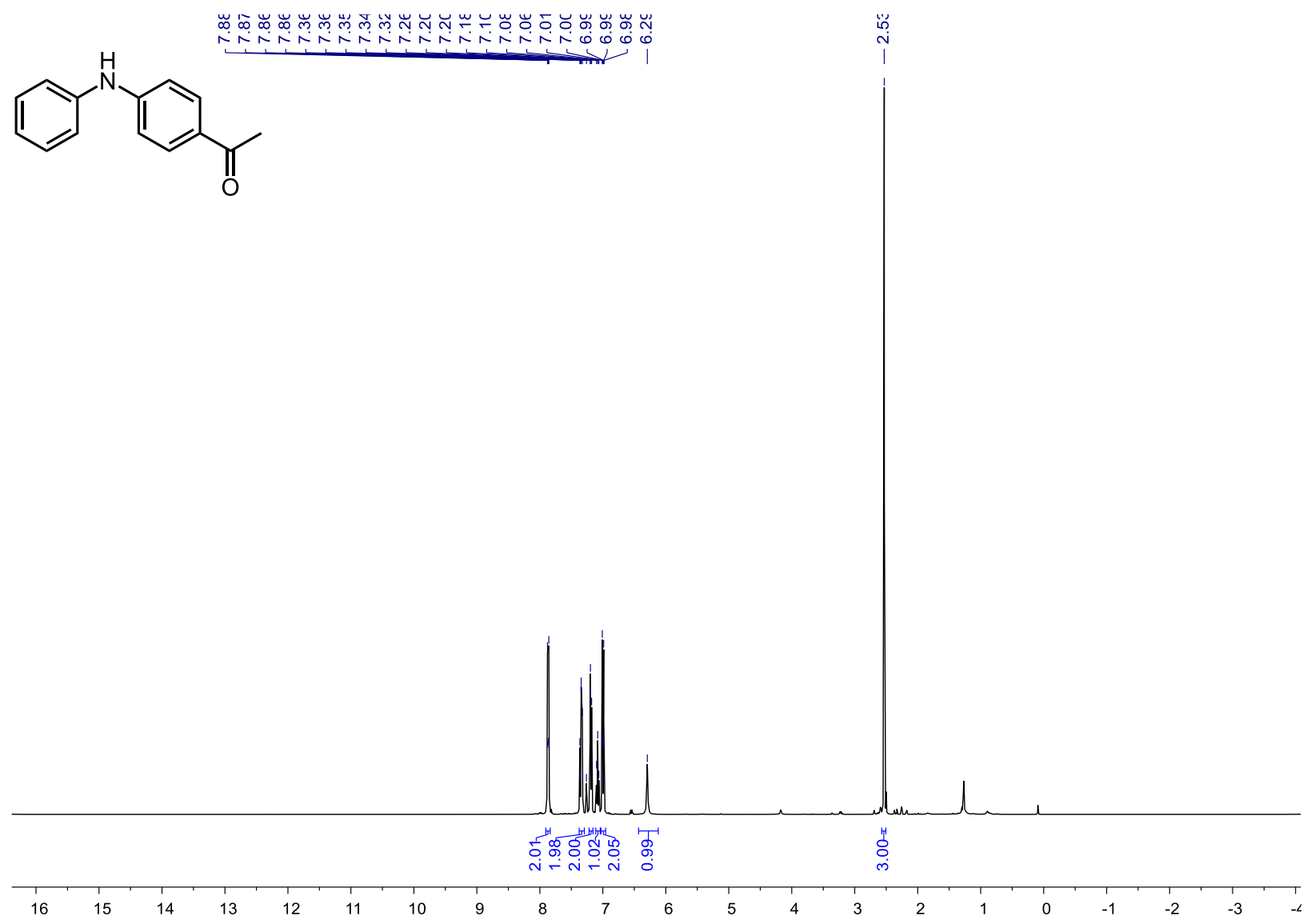

$31-{ }^{13}$ C NMR

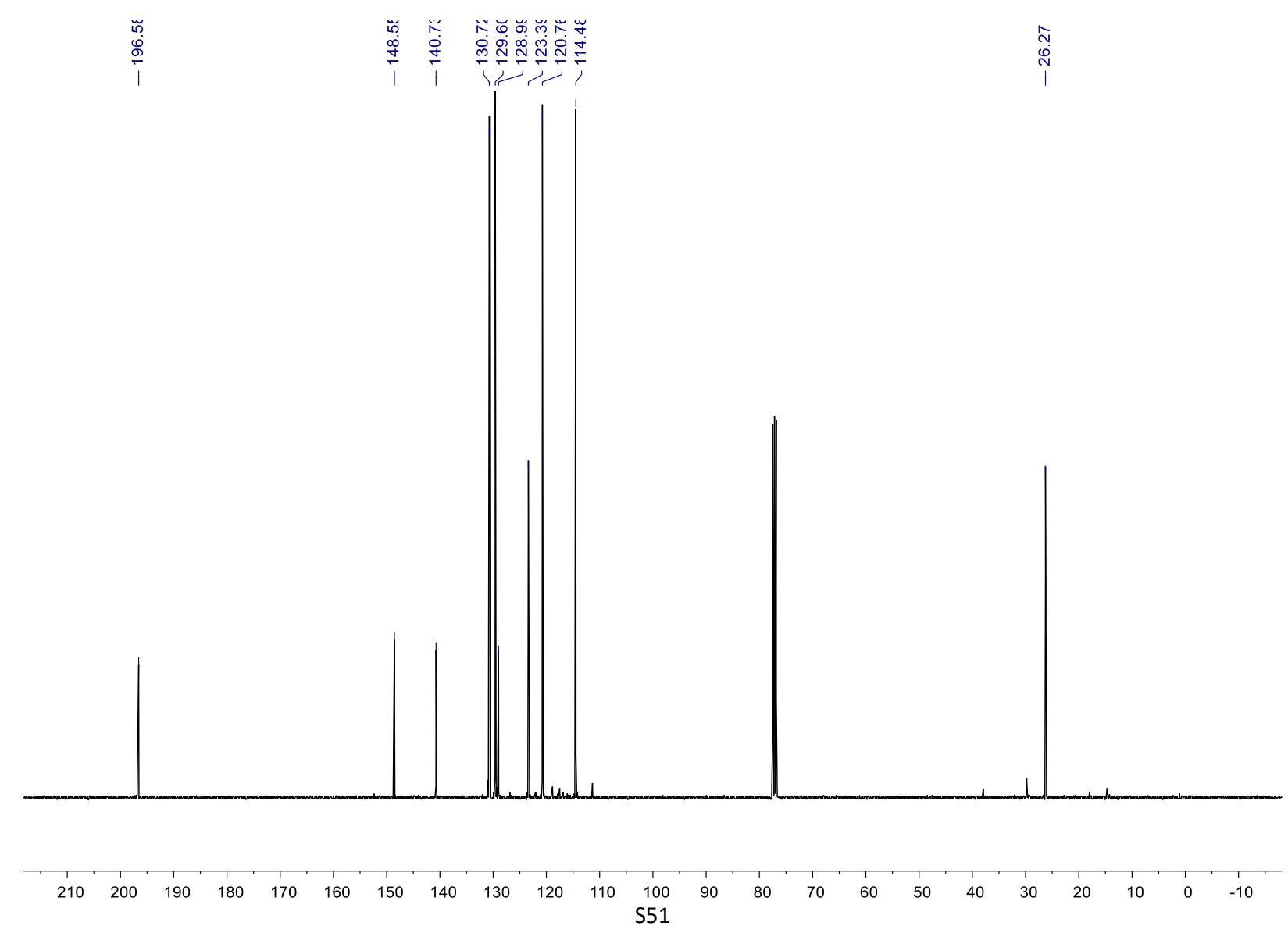


<smiles>COC(=O)c1ccc(Nc2ccccc2)cc1</smiles>

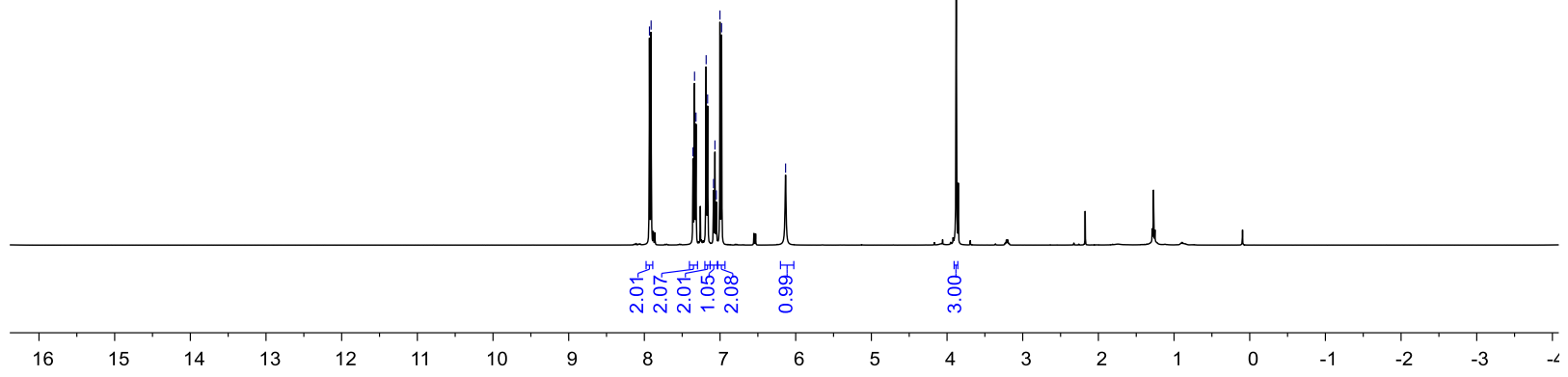

$32-{ }^{13}$ C NMR

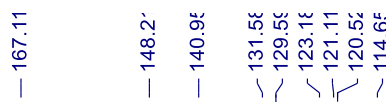

$\stackrel{m}{\infty}$ 
<smiles>FC(F)(F)c1cc(Nc2ccccc2)cc(C(F)(F)F)c1</smiles>

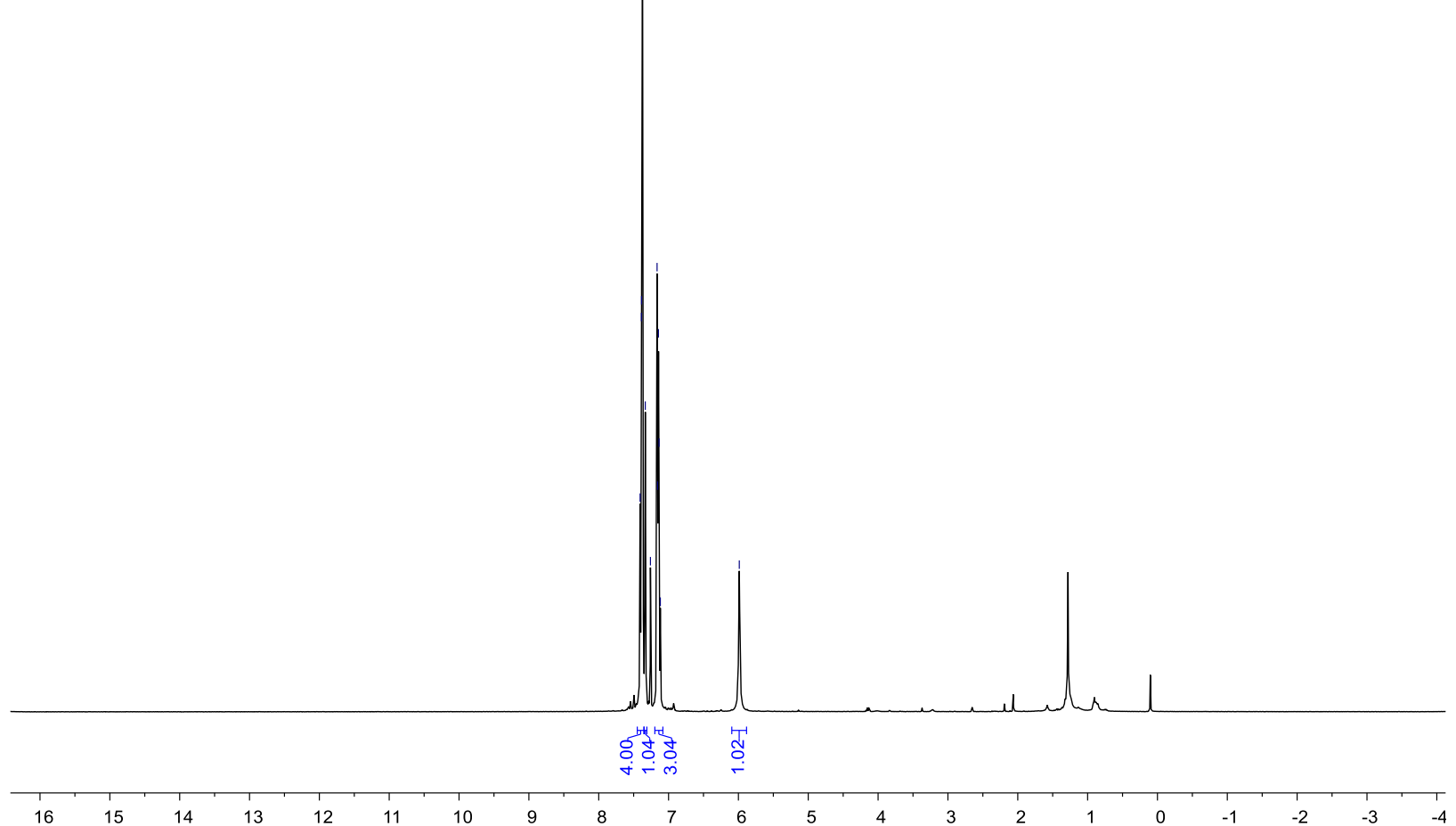

\section{$33-{ }^{13}$ C NMR}




\section{$33-{ }^{19}$ F NMR}

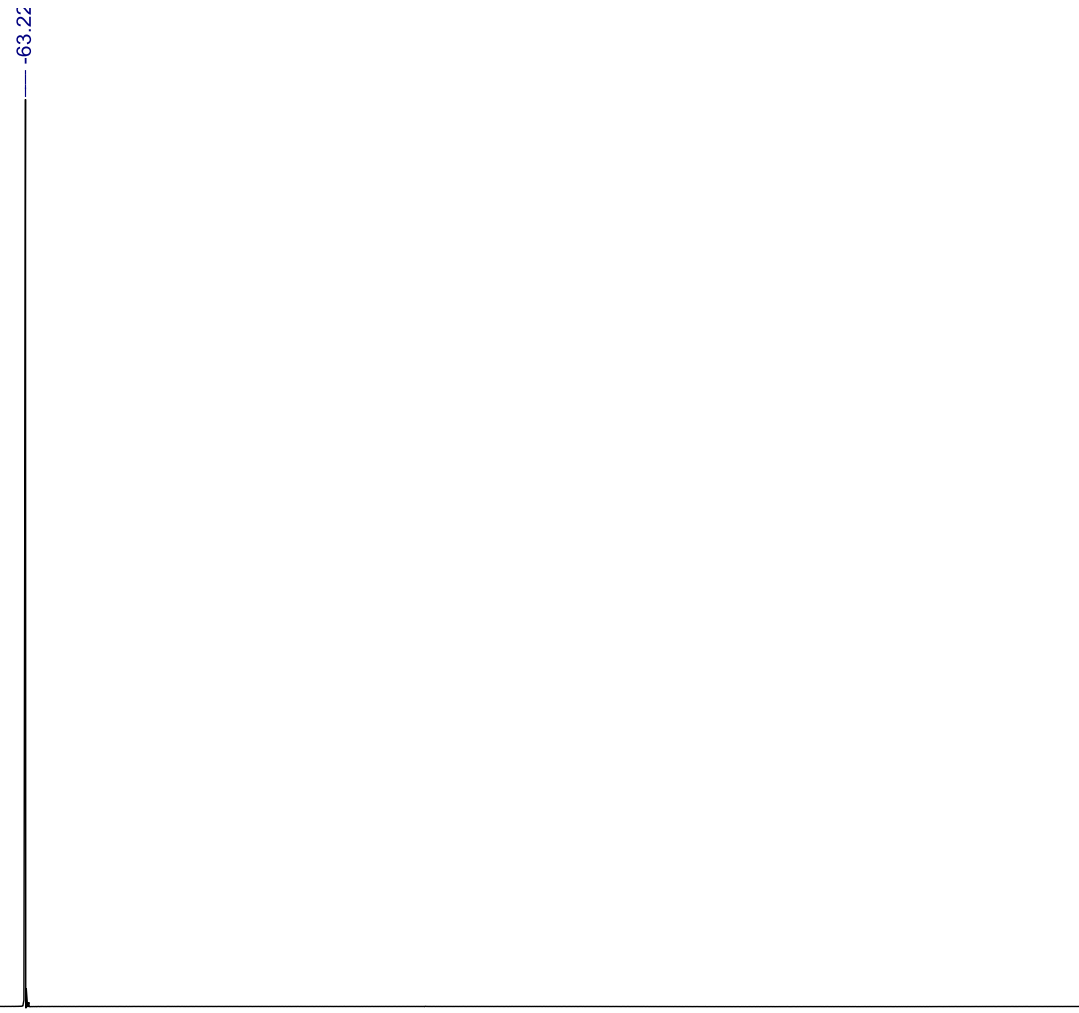

$\begin{array}{llllllllllllllllllllllllllllllllll}10 & 0 & -10 & -20 & -30 & -40 & -50 & -60 & -70 & -80 & -90 & -100 & -110 & -120 & -130 & -140 & -150 & -160 & -170 & -180 & -190 & -200 & -210 & \end{array}$ 


\section{$34-{ }^{1}$ H NMR}<smiles>COc1cc(Nc2ccccc2)cc(OC)c1</smiles>

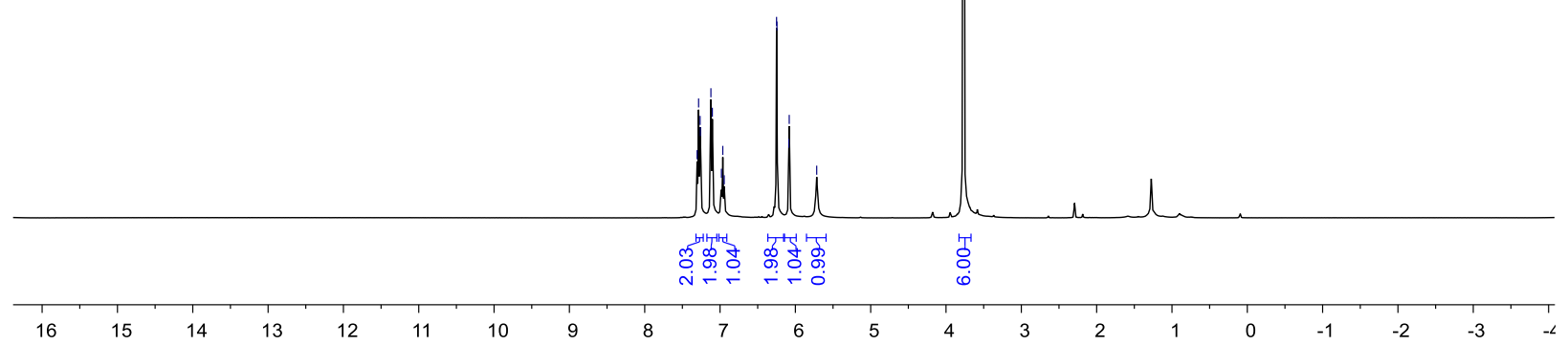

$34-{ }^{13}$ C NMR

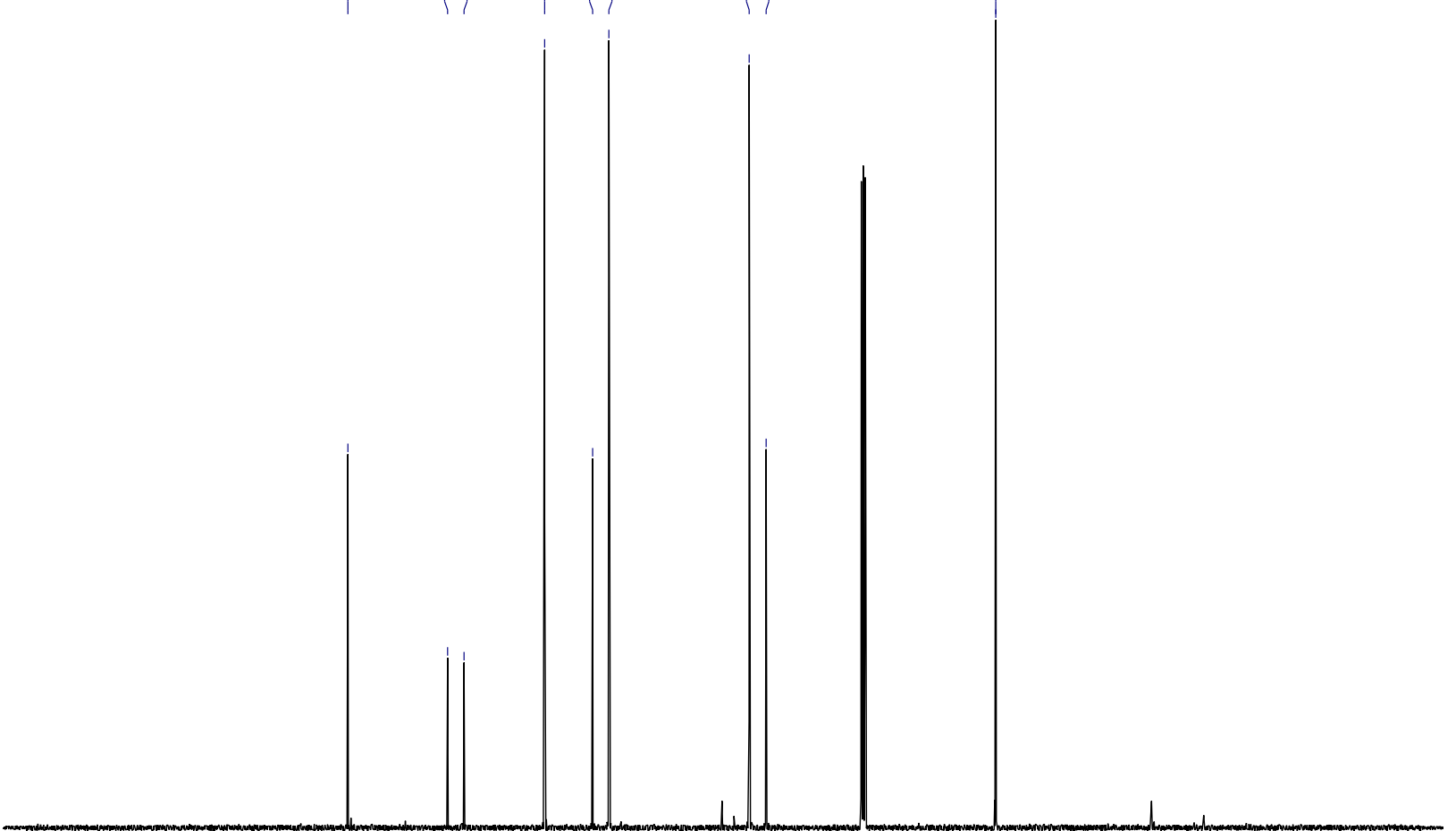


岗<smiles>Fc1ccc(Nc2ccccc2)cc1</smiles>

$-{ }^{13}$ C NMR

แั

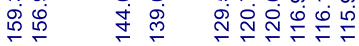

i 


\section{$35-{ }^{17}$ F NMR}

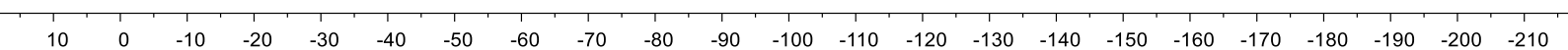




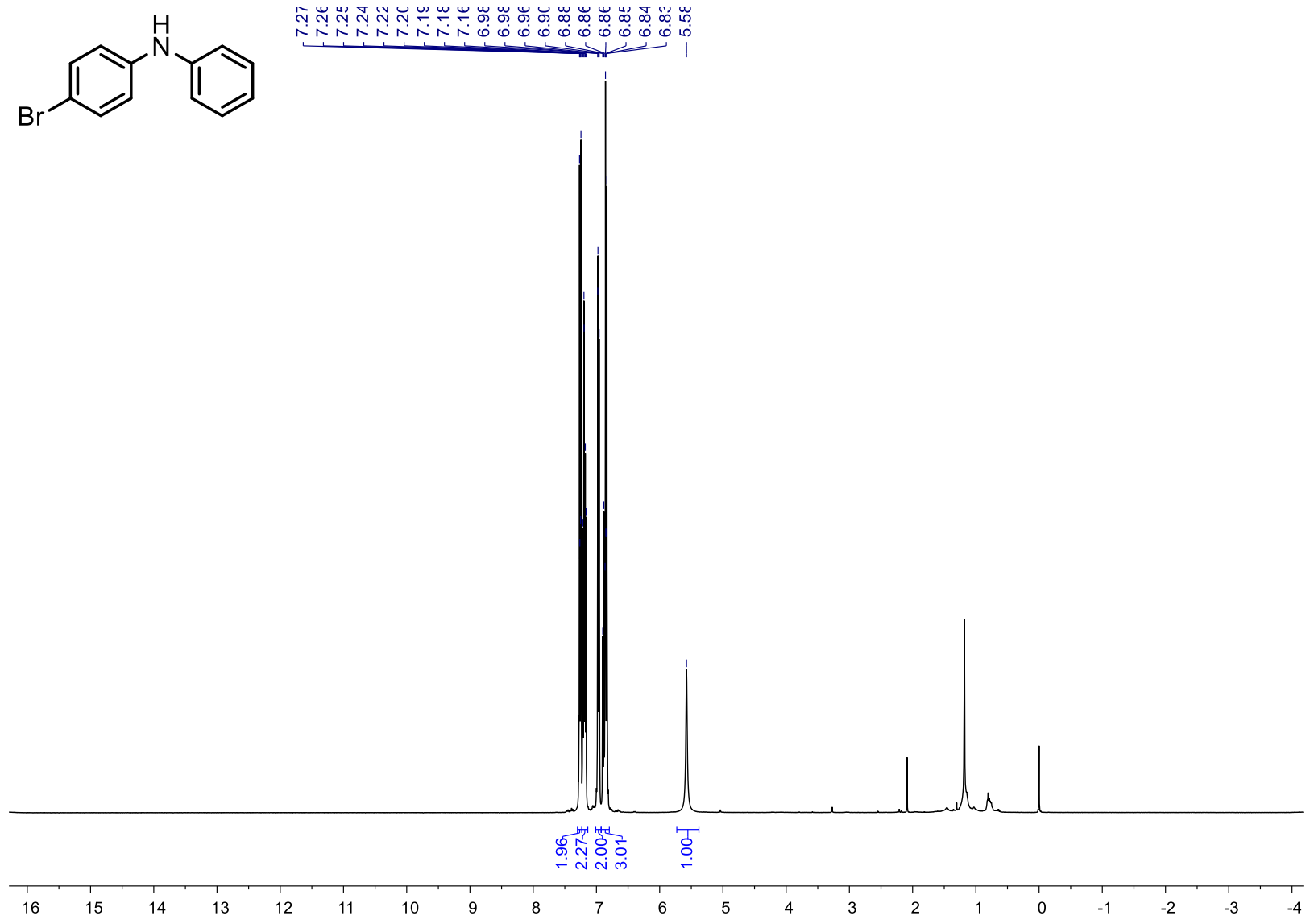

\section{$12 / 36-{ }^{13}$ C NMR}

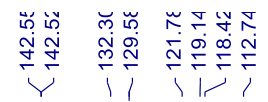




\section{$37-{ }^{1} \mathrm{H}$ NMR}

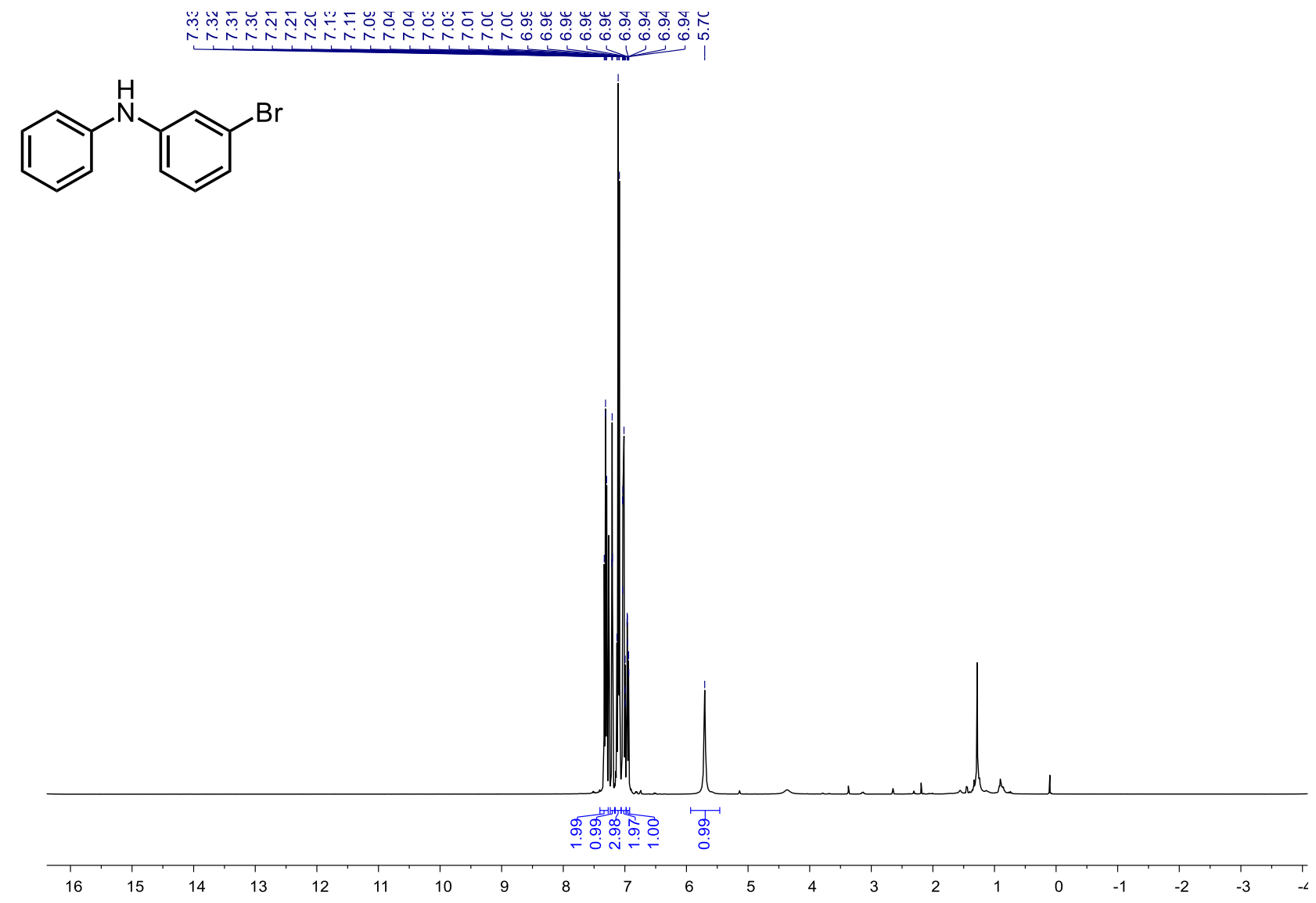

\section{$37-{ }^{13}$ C NMR}

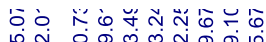

守 状 